San Jose State University

SJSU ScholarWorks

Master's Theses

Master's Theses and Graduate Research

1992

\title{
Feeding ecology of humpback whales in continental shelf waters near Cordell Bank, California
}

Thomas R. Kieckhefer

San Jose State University

Follow this and additional works at: https://scholarworks.sjsu.edu/etd_theses

\section{Recommended Citation}

Kieckhefer, Thomas R., "Feeding ecology of humpback whales in continental shelf waters near Cordell Bank, California" (1992). Master's Theses. 332.

DOI: https://doi.org/10.31979/etd.tq5x-wyfz

https://scholarworks.sjsu.edu/etd_theses/332

This Thesis is brought to you for free and open access by the Master's Theses and Graduate Research at SJSU ScholarWorks. It has been accepted for inclusion in Master's Theses by an authorized administrator of SJSU ScholarWorks. For more information, please contact scholarworks@sjsu.edu. 


\section{INFORMATION TO USERS}

This manuscript has been reproduced from the microfilm master. UMI films the text directly from the original or copy submitted. Thus, some thesis and dissertation copies are in typewriter face, while others may be from any type of computer printer.

The quality of this reproduction is dependent upon the quality of the copy submitted. Broken or indistinct print, colored or poor quality illustrations and photographs, print bleedthrough, substandard margins, and improper alignment can adversely affect reproduction.

In the unlikely event that the author did not send UMI a complete manuscript and there are missing pages, these will be noted. Also, if unauthorized copyright material had to be removed, a note will indicate the deletion.

Oversize materials (e.g., maps, drawings, charts) are reproduced by sectioning the original, beginning at the upper left-hand corner and continuing from left to right in equal sections with small overlaps. Each original is also photographed in one exposure and is included in reduced form at the back of the book.

Photographs included in the original manuscript have been reproduced xerographically in this copy. Higher quality $6^{\prime \prime} \times 9^{\prime \prime}$ black and white photographic prints are available for any photographs or illustrations appearing in this copy for an additional charge. Contact UMI directly to order.

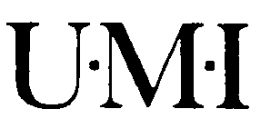

University Microfilms Internatıonal

A Bell \& Howell information Company

300 North Zeeb Road. Ann Arbor, MI 48106-1346 USA

$313 / 761.4700 \quad 800 / 521.0600$ 


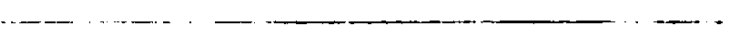


Order Number $1 \$ 48693$

Feeding ecology of humpback whales in continental shelf waters near Cordell Bank, California

Kieckhefer, Thomas Ridgway, M.S.

San Jose State University, 1992 
- …… - - - . $--$ 


\title{
FEEDING ECOLOGY OF HUMPBACK WHALES IN CONTINENTAL SHELF WATERS NEAR CORDELL BANK, CALIFORNIA
}

\author{
A Thesis \\ Presented to \\ The Faculty of the Department of Moss Landing Marine Laboratories \\ San Jose State University \\ In Partial Fulfillment \\ of the Requirements for the Degree \\ Master of Science
}

By

Thomas R. Kieckhefer

May 1992 
APPROVED FOR THE DEPARTMENT OF MOSS LANDING MARINE LABORATORIES
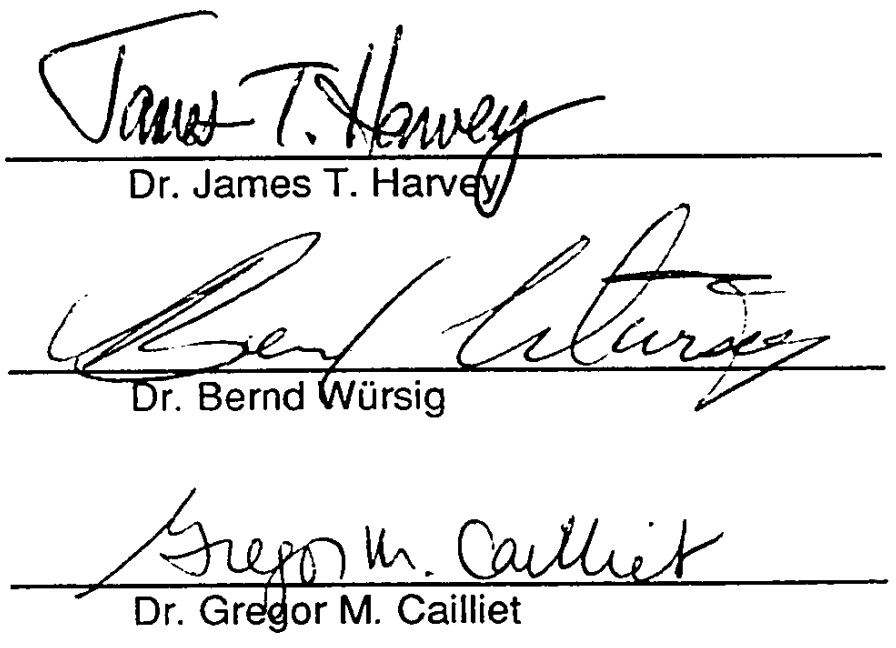

APPROVED FOR THE UNIVERSITY

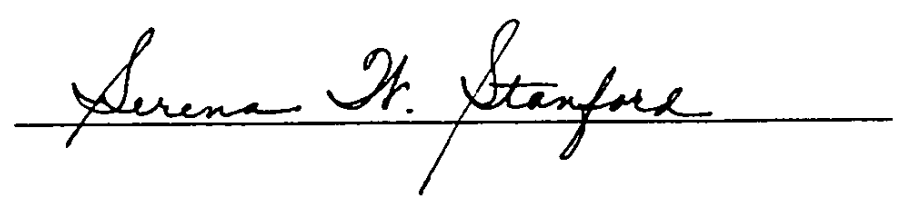




\section{ABSTRACT}

Daytime feeding behavior of humpback whales (Megaptera novaeangliae) in Gulf of the Farallones, California, and adjacent waters was observed during autumn of 1988 to 1990. Bodega Canyon, Cordell Bank, and the Farallon Islands were the primary sites of feeding activity. Fecal samples of whales and zooplankton tows contained euphausiids exclusively, dominated by Thysanoessa spinifera (79\%), with lesser amounts of Euphausia pacifica (14\%), Nyctiphanes simplex (4\%), and Nematoscelis difficilis (3\%). In 1988 and 1990, whales also were infrequently observed feeding on small schooling fish, presumabiy Pacific herring (Clupea pallasii), northern anchovy (Engraulis mordax), and juvenile rockfish (Sebastes spp.).

Feeding was the most common behavior observed $(52 \%)$, and less frequently traveling $(23 \%)$, milling $(21 \%)$, and resting $(4 \%)$. Whales used different methods to consume euphausiid prey at the surface $(0-10 \mathrm{~m})$, in shallow water (11-60 m), and deep water (61-140 m). Humpback whales fed at the surface $56 \%$ of time in 1988 and $32 \%$ of time in 1990 , using primarily lateral lunges to capture swarms of euphausiids. In 1989, no surface feeding was observed; however, deep, long-duration dives were followed by extended surface intervals with many respirations. These 1989 observations coincided with increased prey depth as indicated by depth sounder records of diving whales and prey scattering layers.

In 1989, increased prey depth and associated feeding behaviors were strongly associated with unusually high surface temperatures, calm seas, and changes in water circulation. Environmental conditions in 1989 triggered the most intense and wide-spread occurrence of red tide in this region since 1980 . Red tide samples collected throughout this period contained Alexandrium (=Gonyaulax) catenella and Noctiluca scintillans. Surface feeding was observed only in 1988 and 1990, when surface prey were available and red tides were very limited in extent, duration, and intensity. Annual variations in humpback whale feeding behavior were related to prey availability which is affected by corresponding environmental conditions. 


\section{ACKNOWLEDGMENTS}

This study was made possible thanks to the help of many people and organizations. First, the study could not have been completed without the valuable research assistance of Chris Tanner, Peter Rudolph, Daniel E. Shapiro, Thea Jenssen, Chris Rado, and Birgit Liskey. Thanks to Dr. Bernd Würsig for the use of his Mark III Zodiac in 1988, and his help and support in getting funds for a more seaworthy vessel, the R/V Ridgway (a $6.7 \mathrm{~m}$ Boston Whaler/Guardian equipped with a LORAN, radar, depth sounder, VHF radio, and appropriate safety gear), which was used in 1989 and 1990. Tracy Thomas, Chuck Cheaney, and Mike Prince assisted me in properly outfitting the R/V Ridgway. Thanks to John Calambokidis and Gretchen Steiger (Cascadia Research Collective); Gary Ranos (captain of the S/V laorana); Dan Bockus and Marc Webber (Oceanic Society Expeditions); Dave French and Rick Powers (captains of the F/Vs' New Sea Angler and Jaws); Deke Nelson (captain of the R/V Susan Kay); Ron Blodgett (captain F/V Happy Jack); as well as Bob LaMar (Northern Airventures) for their support out at sea in providing locations of whales, prey and fecal samples, and safety throughout the study. Jo Guerrero, Jill Schoenherr, Janet Stein, Nancy Black, Sheila and Alan Baldridge, Carol Keiper, and Thomas A. Jefferson all gave me inspiration to undertake this project and provided never-ending encouragement. I would like to give a special thanks to William A. Archibald and his family for their unending support and assistance with the computer design of this project, as well as filling my head with all the future possibilities of computer technology. Jim Oakden, Lynn McMasters, and Eric Dorfman provided consultation and assistance with the graphics. I thank Sheila Baldridge (Moss Landing Marine Laboratories) and Eleanor Uhlinger (Bodega Marine Laboratories) for their great assistance in finding valuable references. I thank Susan Smith (Southwest Fisheries Center) for her help identifying euphausiid mandibles, and Gregg Langlios (Department of Health Services, Shellfish Program) for providing the red tide data. Historic humpback whale stomach samples were provided by Dale Rice and Alan Wolman (National Marine Mammal Laboratory). Oceanographic data were provided by David Husby (Pacific Fisheries Environmental Group), and satellite images by Newell Gartield (Naval Postgraduate School). Drs. Bernd Würsig, James Harvey, John Oliver, Peter Klimley, and Gregor Cailliet gave me continual support and guidance. James Harvey, Jo Guerrero, Bernd Würsig, Gregor Cailliet, John Calambokidis, Nancy Black, and Tom Jefferson improved the manuscript with suggestions in their reviews. I would also like to thank the entire staff at Bodega Marine Laboratories and Moss Landing Marine Laboratories for their gracious assistance and encouragement throughout the study. Finally, I would like to thank Mrs. Viola Otis, my family, and relatives, who always believed in me.

Several funding agencies supported this study, including the Gulf of the Farallones National Marine Sanctuary (contract no. CX 8140-0-009); Southwest Fisheries Center (order no. 43NABNF002718 under a subcontract from Cascadia Research Collective); Dr. Earl H. Myers and Ethel M. Myers/Oceanographic and Marine Biology Trust; Lerner-Gray Fund for Marine Research; Sigma Xi, Grants-in-Aid of Research; Packard Foundation; International Research Expeditions; and the Environmental Studies Internship Program at University of California, Santa Cruz.

The R/V Ridgway was funded by: J.W. Kieckhefer Foundation; Margaret T.

Morris Foundation; San Jose State Foundation/Moss Landing Marine Laboratories; and a donation from my father, James $F$. Kieckhefer, for safety equipment. 
TABLE OF CONTENTS

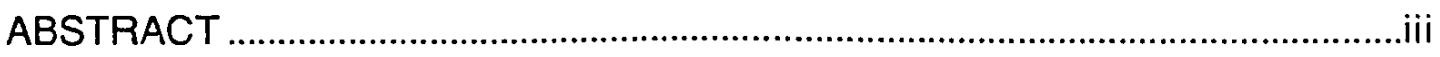

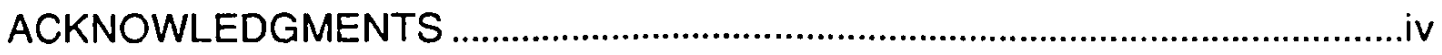

LIST OF TABLES ..........................................................................................

LIST OF FIGURES ................................................................................................

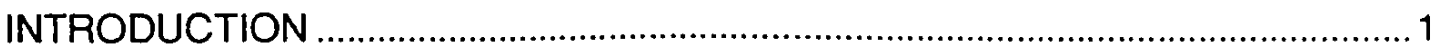

METHODS

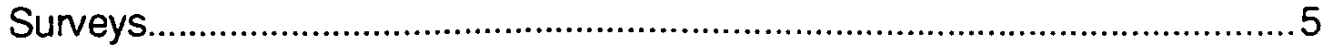

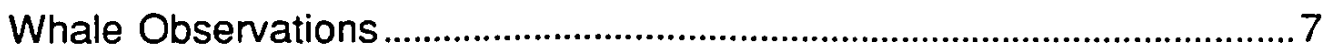

Prey Collections and Documentation .........................................................11

Laboratory Analyses ....................................................................................12

Environmental Data..................................................................................13

RESULTS

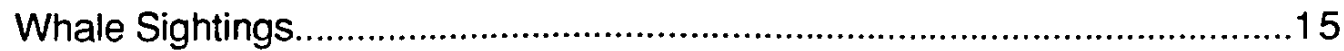

Whale Behavior.....................................................................................17

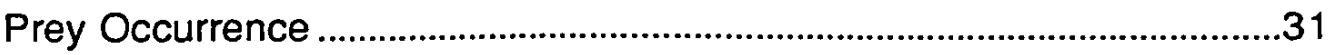

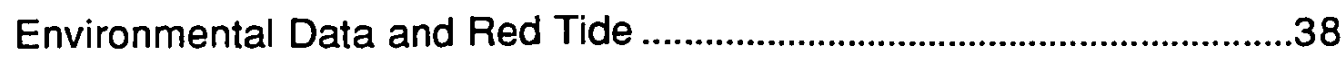

DISCUSSION

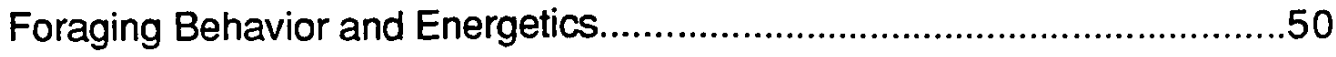

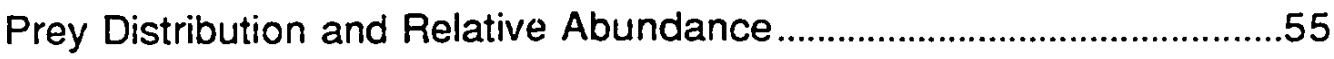

Oceanographic Conditions and Productivity ..............................................60

Correlations between Whale Behavior, Prey Occurrence, and

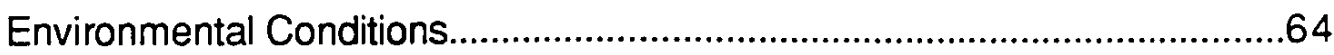

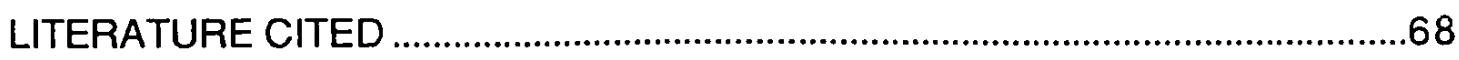

APPENDICES

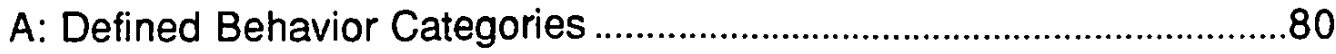

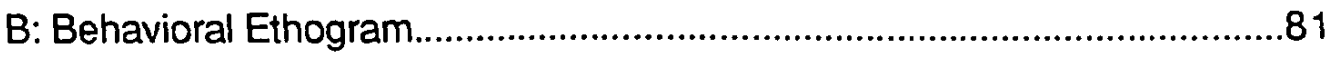

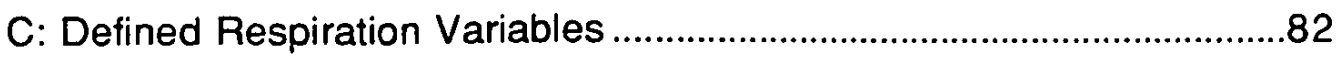

D: Calculated Respiration Variables/ Standard Approach ........................83

E: Standard Body Length and Mandible Measurements...........................84

F: Euphausiid Right Mandible Identification ...............................................85

G: Sky and Sea Condition Codes ..........................................................86 


\section{LIST OF TABLES}

Table 1. Mean humpback whale respiration variables by behavioral categories of feeding, milling, and traveling during the autumn of 1988-1990.

Table 2. Opportunistic recordings of humpback whale sounds in the study area during the autumn of 1988-1990

Table 3. Humpback whale fecal samples collected in the study area during the autumn of $1987-1990$

Table 4. Percentage of euphausiids caught in plankton tows in 1990 at the surface $(0-10 \mathrm{~m})$, shallow (11-60 m), and deep (61-140 m)

Table 5. Location and capture dates of humpback whale stomach contents collected during commercial whaling off Central California from 1960-64 


\section{LIST OF FIGURES}

Figure 1. Study area off central California, 1988-1990 ...................................

Figure 2. Track lines of vessel surveys and range of red tides ...................... 8

Figure 3 . Locations of humpback whales and prey........................................16

Figure 4. Percent frequency of humpback whale behaviors .........................18

Figure 5. Percent frequency of surface, shallow, and deep feeding ..............19

Figure 6. Mean blow rate of feeding, milling, and traveling humpback whales.....................................................................................................21

Figure 7. Surface duration, number of blows per surface duration, and dive duration for feeding at all depths (0-140 m).

Figure 8. Surface duration, number of blows per surface duration, and dive duration of surface $(0-10 \mathrm{~m})$, shallow $(11-60 \mathrm{~m})$, and deep $(61-140 \mathrm{~m})$ feeding.

Figure 9. Surface duration, number of blows per surface duration, and dive duration for 1990 feeding depths.........................................25

Figure 10. Photographs of humpback whale bubble-cloud formation...............26

Figure 11. Percentage of fluke-down, fluke-up, and high fluke-up dives for surface, shallow, deep feeding depths.

Figure 12. Depth sounder records of whales diving at different descent angles

Figure 13. Depth sounder records documenting a deep and shallow scattering layer during 1989.

Figure 14. Length frequency histogram of 1990 tow samples, comparing the lengths of Thysanoessa spinifera to Euphausia pacifica.

Figure 15. Length frequency of Thysanoessa spinifera caught in tows for 1988,1989 , and 1990

Figure 16. Linear regressions of standard body length versus right mandible length of Thysanoessa spinifera and Euphausia pacifica.

Figure 17. Calculated standard body length frequencies for Thysanoessa spinifera and Euphausia pacifica from right mandibles collected in humpback whale fecal samples. 


\section{CONT. LIST OF FIGURES}

Figure 18. Percent frequency of occurrence of Cassin's Auklet, Red Phalarope, and Red-necked Phalarope observed relative to mean prey depth.

Figure 19. Fitted curves comparing mean daily prey depth, surface temperature, Secchi depth, Beaufort state, and bottom depth for the months of September, October, and November in 1989 and 1990.

Figure 20. Linear regressions of prey depth versus surface temperature for 1989 and 1990

Figure 21. Fitted curves comparing mean daily surface light and underwater $(10 \mathrm{~m})$ light to scattering layer depths for the months of September, October, and November in 1990

Figure 22. Monthly mean Paralytic Shellfish Poison (PSP) toxin levels for Marin County, California. and mean prey depth for the months of September, October, and November in 1988-90.

Figure 23. Estimated red tide ranges and durations in 1988-90

Figure 24. Satellite images of sea surface temperature (SST) for the most cloud-free days found in 1989 and 1990.

Figure 25. Monthly coastal upwelling indices and sea surface temperature for July-December 1988-90 


\section{INTRODUCTION}

Most humpback whales (Megaptera novaeangliae) in the northeast Pacific feed in Alaskan waters in summer and breed in waters surrounding Hawaii and Mexico during winter. Each autumn, 100 to 200 individuals, primarily adults from the Mexican group, migrate to the Gulf of the Farallones, California, and adjacent waters to feed (Dohl et al. 1983; Webber and Cooper 1983; Calambokidis et al. 1989a, 1990, 1991a). This central California assemblage of humpback whales was severely depleted during commercial whaling from 1956 to 1965 (Rice 1963, 1971, 1978). Gulf of the Farallones surveys from 1980 to 1982 indicated that numbers of humpback whales were increasing (Dohl 1983; Dohl et al. 1983). However, recent surveys conducted by Cascadia Research Collective from 1986 to 1988 found that the numbers of humpback whales were less than reported in 1982, and no current evidence suggests their recovery (Calambokidis et al. 1989a, 1990, 1991a,b; Steiger et al. 1989). Annual variations in their numbers and distribution were great, which possibly related to the distribution and availability of prey (Calambokidis et al. 1990, 1991b).

Aside from observations of humpback whales feeding in and around the Gulf of the Farallones, little is known about their behavior in these waters. Several studies have quantitatively linked feeding behavior of whales to availability and type of prey (Würsig et al. 1984, 1986; Dolphin 1987a,b,c,d; Hamner et al. 1988; Guerrero 1989). Würsig et al. (1984) found that blow rates of bowhead whales (Balaena mysticetus) feeding in the Arctic decreased when they fed in the water column versus when they were skim feeding at the surface. 
Likewise, Hamner et al. (1988) reported southern right whales (B. australis) slowly moving at the surface and hyperventilating before long dives to feed on sub-surface Antarctic krill (Euphausia superba). Guerrero (1989) found that surface behaviors of gray whales (Eschrichtius robustus) were different when they were feeding on mysid swarms compared with feeding on infaunal amphipods. Dolphin (1987a,b,c,d) found that respiration rates of humpback whales in southeast Alaska were positively correlated with depth of feeding.

Observations of humpback whale surface feeding have confirmed that they have a diverse repertoire of behaviors, such as lunge feeding and "bubblenetting" (Ingebrigsten 1929; Jurasz and Jurasz 1979; Watkins and Schevill 1979; Hain et al. 1982; Baker 1985; D'Vincent et al. 1985). Various prey species or densities may affect these different feeding methods (Jurasz and Jurasz 1979; Watkins and Schevill 1979; Hain et al. 1982; Baker 1985). In lunge feeding, whales display several different behaviors, with variations occurring in their body postures and angles of trajectory from the water's surface. Jurasz and Jurasz (1979) reported lunge angles of $30^{\circ}$ and $90^{\circ}$, which described a lateral and vertical lunge. In addition, diagonal $\left(45^{\circ}\right)$ lunges, with bodies upright and oblique to the water's surface, were used when whales fed on fast, schooling prey (Kieckhefer pers. obs. S.E. Alaska 1982). During bubble-net feeding, a whale forms a circular or cylindrical-shaped screen of bubbles by a series of underwater exhalations, apparently to herd and concentrate prey at the surface (Jurasz and Jurasz 1979). Following the completion of a bubble-net, a vertical lunge is often executed in the center.

In southeast Alaska, apparent cooperative feeding of humpback whales (e.g. 8-11 whales synchronously lunging at the surface capturing herring) have 
been described, and vocalizations may have assisted in corralling fish prey or coordinating whale efforts (Baker 1985; D'Vincent et al. 1985). In the same area, two to four whales eschelon feeding or surface lunge-feeding in staggered formation has been observed (Jurasz and Jurasz 1979; Baker 1985). Eschelon formations have also been reported in skim-feeding bowhead whales (B. mysticetus; Würsig et al. 1984; Würsig 1988).

Prey of humpback whales in the North Pacific were identified in samples obtained during whale feeding (Jurasz and Jurasz 1979; Wing and Krieger 1983; Krieger and Wing 1984; D'Vincent et al. 1985; Baker 1984; Dolphin 1987a,b; Krieger 1988) and in stomach contents of stranded animals and carcasses examined at whaling stations (Mathews 1937; Rice 1963, 1977; Nemoto 1970; Calambokidis et al. 1989a). Humpback whales, in southeast Alaska, fed mainly on euphausiids, especially Thysanoessa rashii, and less on Euphausia pacifica, Thysanoessa longipes, and Thysanoessa spinifera (Wing and Krieger 1983; Krieger and Wing 1984; Dolphin 1987a,b). Their diet also includes schooling fishes, such as Pacific herring (Clupea pallasii), capelin (Mallotus villosus), and walleye pollock (Theragra chalcogramma; Wing and Krieger 1983; Krieger and Wing 1984). During 1956-65, commercially killed whales from the Cordell Bank/Gulf of the Farallones area contained anchovies and euphausiids. Stomach contents contained roughly $60 \%$ northern anchovy (Engraulis mordax) and $40 \%$ Euphausia pacifica, with only trace amounts $(<0.5 \%)$ of Pacific herring, Thysanoessa spinifera , shrimp, and rockfish (Sebastes spp.; Rice 1977; Calambokidis et al. 1989a). Distribution and abundance of prey changed annually.

Seasonally, there is an abundant supply of juvenile schooling rockfish, 
especially shortbelly (Sebastes jordanı), chilipepper (S. goodel), bocaccio (S. paucispinis), and yellowtail rockfish (S. flavidus) in the Cordell Bank/Gulf of the Farallones area, which are potential prey items for humpback whales (Larson 1987; D. Pearson pers. comm. 1988; Hobson and Howard 1989). In addition, Smith and Adarns (1988) found abundant surface swarms of $T$. spinifera off the Farallon Islands.

Combined with concurrent studies of whale distribution, movements, and population size, this study proposes to accurately describe the importance of this region as a food resource to this remnant group of humpback whales. To investigate the feeding ecology of humpback whales near Cordell Bank/ Gulf of the Farallones, five objectives were pursued: (1) assess percentage of time spent feeding compared with other behavioral states of rest, slow travel, fast travel, and mill/search; (2) quantify respirations and surface behaviors associated with feeding (surface and sub-surface) and non-feeding; (3) characterize feeding behavior for different types of prey (e.g. euphausiids vs. fish, shallow vs. deep prey); (4) identify prey species and determine their depth in the water column; and (5) relate the distribution of prey to topographic features and annual variations of environmental factors. 


\section{METHODS}

\section{Surveys}

From 21 August to 5 November i988, 26 August to 3 December 1989, and 29 August to 12 December 1990, data were collected in and around Cordell Bank and the Gulf of the Farallones (Fig. 1). In 1988, a 4.9-m Mark III Zodiac with a 25 HP outboard motor was used, and in 1989 and 1990 a $6.7 \mathrm{~m}$ Boston Whaler with a main 175 HP outboard engine and a 30 HP auxiliary engine was used. Both vessels were docked in Bodega Bay, and equipped with a VHF radio, LORAN, and Lowrance $X-16$ depth sounder $\left(192 \mathrm{kHz}, 20^{\circ}\right.$ cone angle). Mean scattering layer depths were visually estimated from the thickness of the echo traces and measured to the nearest meter in the water column. A portable time/event recorder (Tandy 102-32K) was interfaced with the vessel's LORAN and an external portable hard drive. During surveys, the vessels' speed, direction, and location were automatically recorded every 10 min into the time/event recorder and the external portable disk drive provided unlimited storage space. Other information consistently recorded during surveys included: number and species of birds present within $300 \mathrm{~m}$; scattering layer depth $( \pm 1.0 \mathrm{~m})$; and bottom depth $( \pm 1.0 \mathrm{~m})$; and environmental data (discussed later).

Aerial surveys of the study area were conducted opportunistically to document whale distribution, abundance, and movement patterns (Calambokidis et al. 1989a, 1991a). In addition, Oceanic Society Expeditions reported whale sightings near the Farallon Islands, and local commercial fishermen and party-boat skippers reported sightings around Cordell Bank and along the coast. 


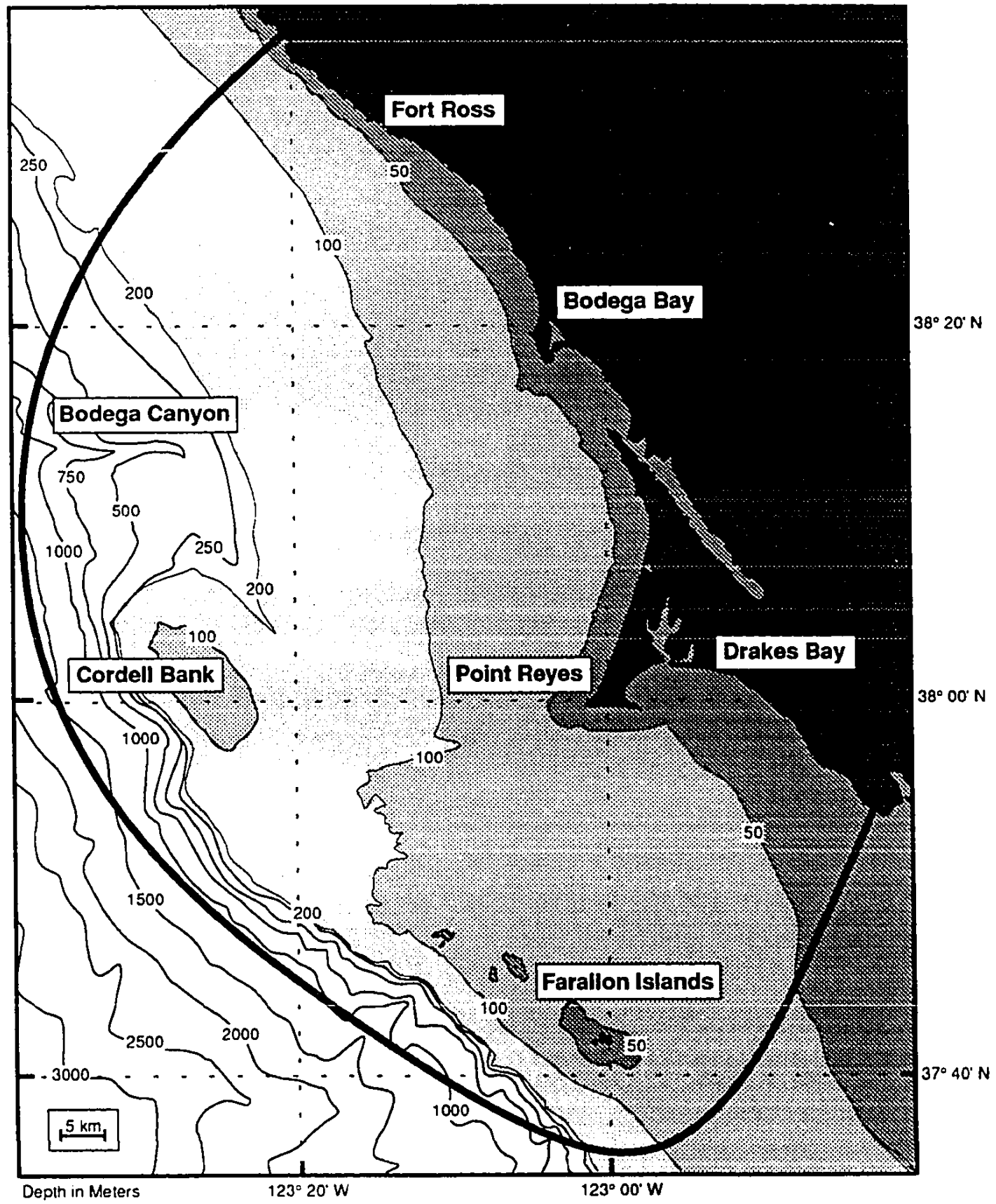

Figure 1. Humpback whale study area off central California (outlined) and geographical regions, Bodega Canyon, Cordell Bank, and the Farallon Islands referred to throughout the text as the primary sites of feeding activity. The study area was approximately $2600 \mathrm{~km}^{2}$, which included Cordell Bank and the Gulf of the Farallones National Marine Sanctuaries. 
Sampling effort usually occurred in areas of greatest whale concentrations, most frequently along Bodega Canyon, Cordell Bank, and the Farallon Islands (Fig. 2). Daily reports of the locations of whales determined our vessel course each day. Individual whales were tracked for approximately 30 minutes, during which time their location and behavioral states were recorded. To minimize disturbance of whales during behavioral observations, the boat remained $>100 \mathrm{~m}$ from whales, which is a National Marine Fisheries Service guideline (Federal Register 1979). In addition, the smaller engine was used approximately $20 \mathrm{~min}$ before and during the observation period. The motor was run at a constant speed to avoid noise associated with throttle shift, which causes a ratchet-like sound underwater and changes in pitch (Baker et al. 1983; Kieckhefer pers. obs. 1985; Bauer 1986; Watkins 1986; Dolphin 1987a,b,c,d; Whitehead and Carlson 1988). Work was conducted under permits obtained by National Marine Fisheries Service (no. 579, 1988 and 1989 and no. 703, 1990) and the Department of Fish and Game (no. 2253, 2153, and 7022, respective years).

\section{Whale Observations}

Two to four boat crew described individual whale behaviors and respiration patterns, and entered behavioral codes and comments into the time/event recorder. At the start and end of each whale observation the following data were recorded: time, date, position, sighting number for the day, group size, number of calves, number of boats and ships present within $2 \mathrm{~km}$, number and species of birds present within $300 \mathrm{~m}$, mean scattering layer depth, bottom depth, and environmental and sea conditions. 

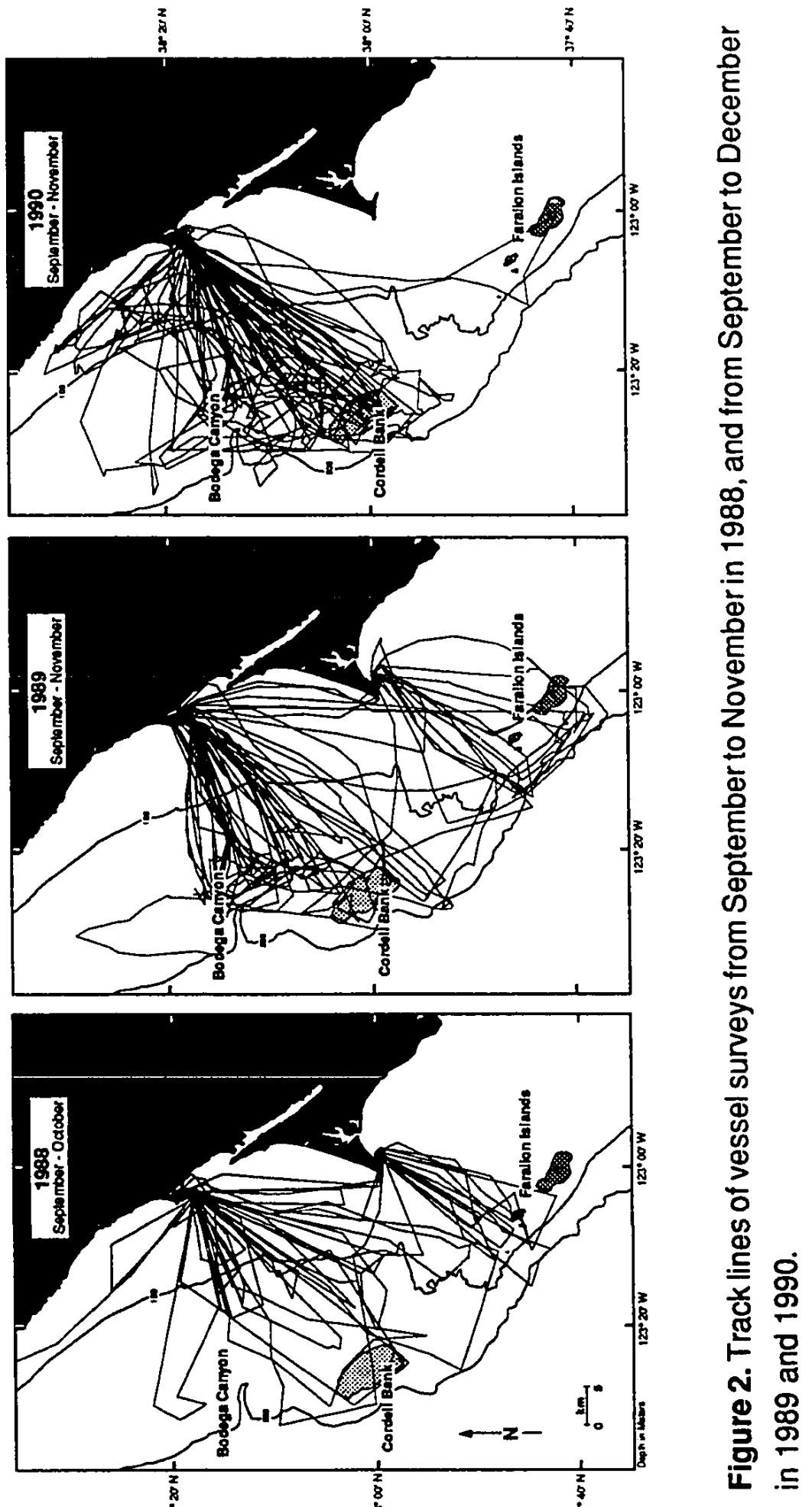
A group was defined as whales within five body lengths of each other (Würsig et al. 1986). Whale behaviors were categorized into 7 different states: rest, slow travel, fast travel, mill/search, surface feed, shallow feed, and deep feed (Appendix A). Behavioral categories were recorded throughout the observation period. Surface (0-10 $\mathrm{m}$ depth) feeding was the most obvious with behaviors such as, lateral, diagonal, and vertical lunging. Shallow (11-60 m) and deep (61-140 m) feeding depths of whales were indirectly determined from the occurrence of the scattering layer and echo traces of swimming whales.

Unique whales (ones with distinctive dorsal fin shapes or pigmentation) of groups were identified and tracked with $7 \times 50$ binoculars (Fujinon). All surfacings, respirations, dives, and aerial behaviors were systematically entered into the portable time/event recorder (Baker et al. 1983; Würsig et al. 1984, 1986; Bauer 1986; Appendix B). Five respiratory variables were recorded: blow interval, number of respirations (blows) per surface duration, duration at surface, dive duration, and blow rate (Würsig et al. 1984, 1986; Dolphin 1987a; Appendix C). Duration at the surface included whales near the surface and blow intervals less than 90 seconds. Duration of dive was the period of time spent diving below the near-surface waters (approx. $5 \mathrm{~m}$ depth) and was distinguished by blow intervals greater than $90 \mathrm{sec}$ or by posturing of tail stock (arched peduncle or raised flukes). All feeding behaviors (i.e. lateral lunging, diagonal lunging, and shallow vs. deep dives) were quantitatively documented.

Opportunistic recordings of whale vocalizations were made on Marantz PMD-430 tape recording with a sonobuoy hydrophone and preamplifier. Sounds were categorized as feeding (uniform; D'Vincent et al. 1985), social 
(unpatterned; Silber 1986), and songs (patterned; Payne and McVay 1971). All recording levels were constant throughout the study. Whale distance was estimated by volume level of recordings. After behavioral observations were concluded, all whales were approached slowly from behind, within $100 \mathrm{~m}$ when possible, photographed and identified by differences in dorsal fin shapes and pigmentation patterns on the ventral surface of their flukes (Katona et al. 1979). Various feeding behaviors also were photographically documented at this time. After photographs were taken, a new group of humpback whales would be located for observation.

Because successive respiration variables of whales were not independent data points, this "standard" approach (e.g. Dolphin 1987b,c ; Guerrero 1989; Harvey and Mate, 1984; Würsig et al. 1984,1986) was not used in the statistical analyses. For comparative purposes to other studies using the standardized approach see Appendix D.

To statistically test data correctly with observations independent of the mean, the mean of each individual whale was calculated and analyzed (Zar 1984; Hoeskstra and Jansen 1986). Nonparametric statistics were used on all respiration variables analyzed due to their skewed distributions. Comparisons among years of mean surface duration, number of blows per surfacing, dive duration, and blow rate within each behavior category were tested using a Kruskal-Wallis test ( 3 group) and Mann-Whitney U-test ( 2 group) at the $P \leq 0.05$ significance level. Means of respiration variables were calculated for each behavior category except for rest, which was rarely observed. A nonparametric Tukey-type multiple comparison test (with unequal sample sizes) was used to determine between year differences. All behavioral observations were of 
unique adults and whales older than two years under "undisturbed" conditions (other vessels $>2 \mathrm{~km}$ away). Statistical methods followed Zar (1984).

\section{Prey Collections and Documentation}

Prey information (samples, depth records) was collected only after observing a focal whale for at least $\mathbf{3 0} \mathrm{min}$. Presence (or absence) of scattering layers, and their mean depth in the water column, were continuously recorded while passing through areas where whales were feeding. Prey were captured with a dip net, horizontal tows with a plankton net $(0.75 \mathrm{~m}$ diameter, $505 \mu \mathrm{m}$ mesh), or jigging with hook and line.

For surface $(0-10 \mathrm{~m})$ plankton tows, the net was towed horizontally at the corresponding prey depth obtained from the depth sounder for 10 to $20 \mathrm{~min}$ at an average boat speed of $4-6 \mathrm{~km} / \mathrm{h}$. Indirect methods of identifying deep prey layers were used in 1988 and 1989 (e.g. stomach content analysis of local salmon and rockfish caught in areas where whales were feeding). Shallow $(11-60 \mathrm{~m})$ and deep $(61-140 \mathrm{~m})$ zooplankton net tows in 1990 were used to quantify the relative percentage of euphausiids and other zooplankton in areas where whales were feeding. Once mean depth of prey was determined on the depth sounder, a $12 \mathrm{~kg}$ lead ball was attached to the net's stainless steel hoop and the appropriate amount of line released. A wire angle was used to determine the amount of line required (hypotenuse) to sample within the targeted scattering layer. The net was towed at a constant speed (approx. $4-6 \mathrm{~km} / \mathrm{h}$ ) and course for 10 to $20 \mathrm{~min}$. 


\section{Laboratory Analyses}

Plankton samples were fixed in $10 \%$ formalin within $8 \mathrm{hrs}$ of collection, and later transferred to $40 \%$ ethanol before analyses. Samples were split into approximately $50 \mathrm{ml}$ volumes with a Folsom plankton splitter. Using an Olympus dissecting microscope (10x to $40 x$ ), euphausiids were sorted, identified to species (Kathman et al. 1986), and counted.

Standard body length (tip of rostrum to tip of telson) was measured to the nearest millimeter for all Thysanoessa spinifera and Euphausia pacifica (Appendix E). Length comparisons of $T$. spinifera and E. pacifica were completed for 1990 only, because the previous years' towing gear did not provide adequate means of sampling deep-dwelling E. pacifica. Fertilized females of $T$. spinifera were distinguished by the presence of brownish, barbellshaped spermatophores. Size-frequency distributions were generated for pooled data for each year. Distributions of T. spinifera and E. pacifica for 1990 and distributions of $T$. spinifera for 1988,1989 , and 1990 were statistically compared using Kolmogorov-Smirnov tests for difference in relative cumulative frequency distributions.

Humpback whale fecal samples were collected opportunistically using a $1 \mathrm{~mm}$ mesh net, bailing bucket, plastic bag, or nylon stocking. Samples were divided and preserved in 10\% formalin and $40 \%$ ethanol (the latter was used due to a concern that $10 \%$ formalin might dissolve fish otoliths). All fish otoliths, and euphausiid right mandibles (Appendix F) and spermatophores were identified to species and counted from 5-ml aliquots of each sample.

Total body length of $T$. spinifera and $E$. pacifica were estimated from a regression equation applied to lengths of mandibles found in fecal samples. 
Total body length classes of $10 \mathrm{~mm}, 15 \mathrm{~mm}$, and $20 \mathrm{~mm}$ for $T$. spinifera $(n=169)$ and $E$. pacifica $(n=144)$ taken trom plankton samples were equally selected and measured to the nearest millimeter. Right mandibles were removed and measured (tip of incisors to tip of mandibular insertion) to $\pm 0.1 \mathrm{~mm}$ with an Olympus Image Analyzer (Appendix E, F). Regression functions of total body length and total mandible length were calculated for both $T$. spinifera and E. pacifica.

\section{Environmental Data}

Environmental data were entered into the time/event recorder every survey hour or new whale sighting, and were updated as necessary every 10 min. Data included: sky condition and sea state (Appendix G), swell height $( \pm 0.5 \mathrm{~m})$, secchi depth $( \pm 0.1 \mathrm{~m})$, sea surface temperature $\left( \pm 0.2^{\circ} \mathrm{C}\right)$, along with bottom depth and mean scattering layer depth. Secchi depths were collected with a circular white-vinyl disk of $27-\mathrm{cm}$ diameter and measured as described in Preisendorfer (1986). Sea surface temperature data were collected with a calibrated Micronta digital thermometer

Throughout each survey, a separate computer (LI-COR DataLogger) was programmed to continually record average surface light levels every $10 \mathrm{~min}$ from a fixed directional light meter (Quantum 2700). Light levels were measured in $\mu \mathrm{E} \mathrm{m}^{-2} \mathrm{~s}^{-1}$, where $2000 \mu \mathrm{E} \mathrm{m}^{-2} \mathrm{~s}^{-1}$ was equivalent to a clear and sunny sky at 12 noon. Total light energy was restricted to the wavelengths between 300 and $720 \mathrm{~nm}$ or photosynthetically available radiation (PAR). Average light levels were measured instead of instantaneous levels due to rough sea conditions and continual pitch and roll of the research vessel. Light penetrating the water 
to a depth of $10 \mathrm{~m}$ was calculated from secchi depth using the vertical extinction coefficient as described in Parsons et al. (1984).

Other indicators of changing environmental conditions such as occurrence of red tide blooms, sea birds, fish, and turtles in the study area were noted and their positions recorded. Red tide samples were collected (via 303 $\mu \mathrm{m}$ mesh net or wide-mouth sample jar) and brought to the laboratory for identification.

Polynomial curves (2-degree) were fitted to daily mean scattering layer depth, sea surface temperature, Secchi depth, Beaufort state, and bottom depth for all whale sightings collected in 1989 and 1990. To determine if an environmental variable(s) had a significant effect on the vertical distribution of the scattering layer during 1989 and 1990, a stepwise regression at the $P \leq 0.05$ significance level was applied. Daily mean light measurements and corresponding scattering layer depths were analyzed separately. Monthly coastal upwelling indices at $39^{\circ} \mathrm{N}, 125^{\circ} \mathrm{W}$ and sea surface temperature at NOAA buoy $46013\left(38.2^{\circ} \mathrm{N}, 123.3^{\circ} \mathrm{W}\right)$ were compared from July through December 1989-90. In addition, archived satellite images of sea surface temperature (SST) were studied and images that clearly show the oceanographic conditions in the study area from July through December 1989-90, were processed at the Naval Postgraduate School in Monterey, California. 


\section{RESULTS}

\section{Whale Sightings}

Humpback whale groups were observed for 232 hours during autumn of 1988, 1989 and 1990. Whale behavior was recorded on 26 groups (27 h) during 31 days at sea in 1988, 99 groups ( 96 h) during 53 days in 1989, and 146 groups (109 h) during 56 days in 1990. During these periods, mean group size was 2.1 to 3.0 individuals (1988: $2.5 \pm 1.38 \mathrm{SD}$, range $=1-6 ; 1989$ : 3.0 $\pm 1.73 \mathrm{SD}$, range $=1-12 ; 1990: 2.1 \pm 1.29 \mathrm{SD}$, range $=1-12)$. Detailed observations of respiration patterns and other surface activity were made on 138 different individuals: 23 in 1988 (12.5 total hours), 51 in 1989 (25.8 hours), and 64 in 1990 (25.0 hours).

Locations of humpback whale observations varied among years. In 1988, humpback whales and prey were dispersed and did not feed for long periods of time at one location. In 1989, concentrations of whales were located west of the Farallon Islands in September and near Cordell Bank and Bodega Canyon in mid-October and November. In mid-September 1990, whales were found in shallow waters near Fort Ross, whereas in October and November concentrations of whales occurred around Bodega Canyon and Cordell Bank (Fig. 3).

Mother-calf pairs were observed infrequently in all 3 years. In 1988, two sightings were made near North Farallon Island. Two sightings occurred near southeast Farallon Island in 1989, and eight sightings near Bodega Canyon and Cordell Bank were recorded in 1990. 

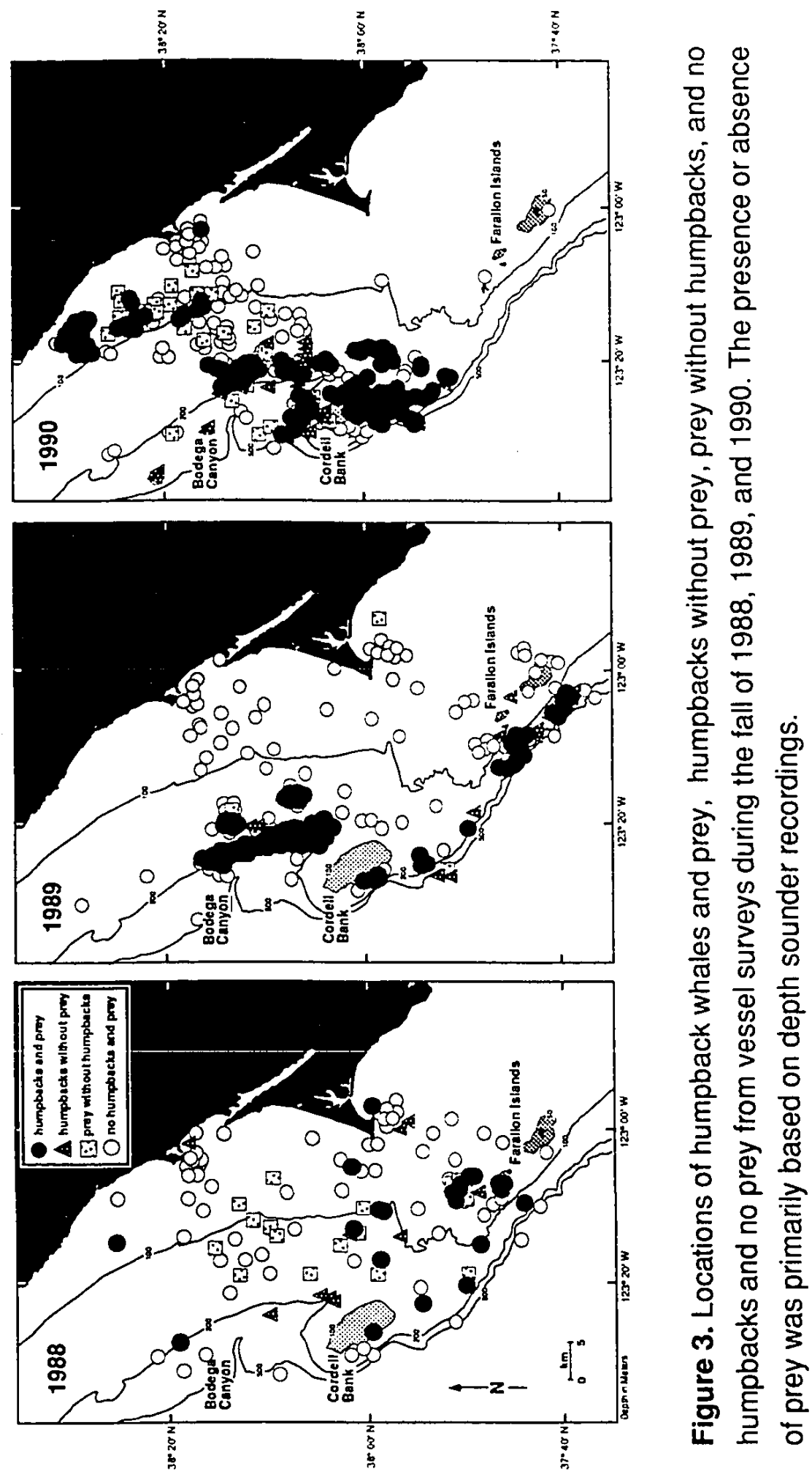


\section{Whale Behavior}

Feeding was the most prevalent activity observed in all three years, comprising about half the total percent frequency of occurrence (mean $=51.4 \%$ \pm 4.94 SD; Fig. 4). Mill/search behavior and slow travel occurred less often than feeding, and were seen with comparable frequency throughout the study (mean $=21.5 \pm 2.04 \mathrm{SD}$ and $16.4 \pm 1.07 \mathrm{SD}$, respectively). Fast travel and rest occurred infrequently (mean $=6.5 \pm 1.87 \mathrm{SD}$ and $4.2 \pm 4.08 \mathrm{SD}$, respectively) in all three years (Fig. 4).

Feeding depth varied significantly among years according to changes in depth of prey $\left(X^{2}=115.5, d f=4, P<0.001\right.$; Fig. 5$)$. Surface feeding $(0-10 \mathrm{~m}$ prey depth) was observed in 1988 and 1990, but was not seen in 1989. Deep sub-surface feeding (61-140 m prey depth) occurred mainly in 1989, less frequently in 1990, and was not observed in 1988. Shallow sub-surface feeding (11-60 m prey depth) occurred in all years.

Respiration variables were recorded for each behavior category except for rest, which was rarely observed (Table 1). Among-year differences in mean blow rate were significant only for feeding and milling behaviors $(H=7.95$, $P<0.01$ and $H=6.53, P<0.05 ; d f=2 ;$ Fig. 6 ). When feeding, blow rate was less in 1989 than either 1988 or 1990; however, mean blow rates were statistically different only when 1988 and 1989 were compared (1.7 vs. 1.1; $Q=2.80, d f=3, P<0.01)$. There was no difference in mean blow rate among years when whales were engaged in slow travel and fast travel. 


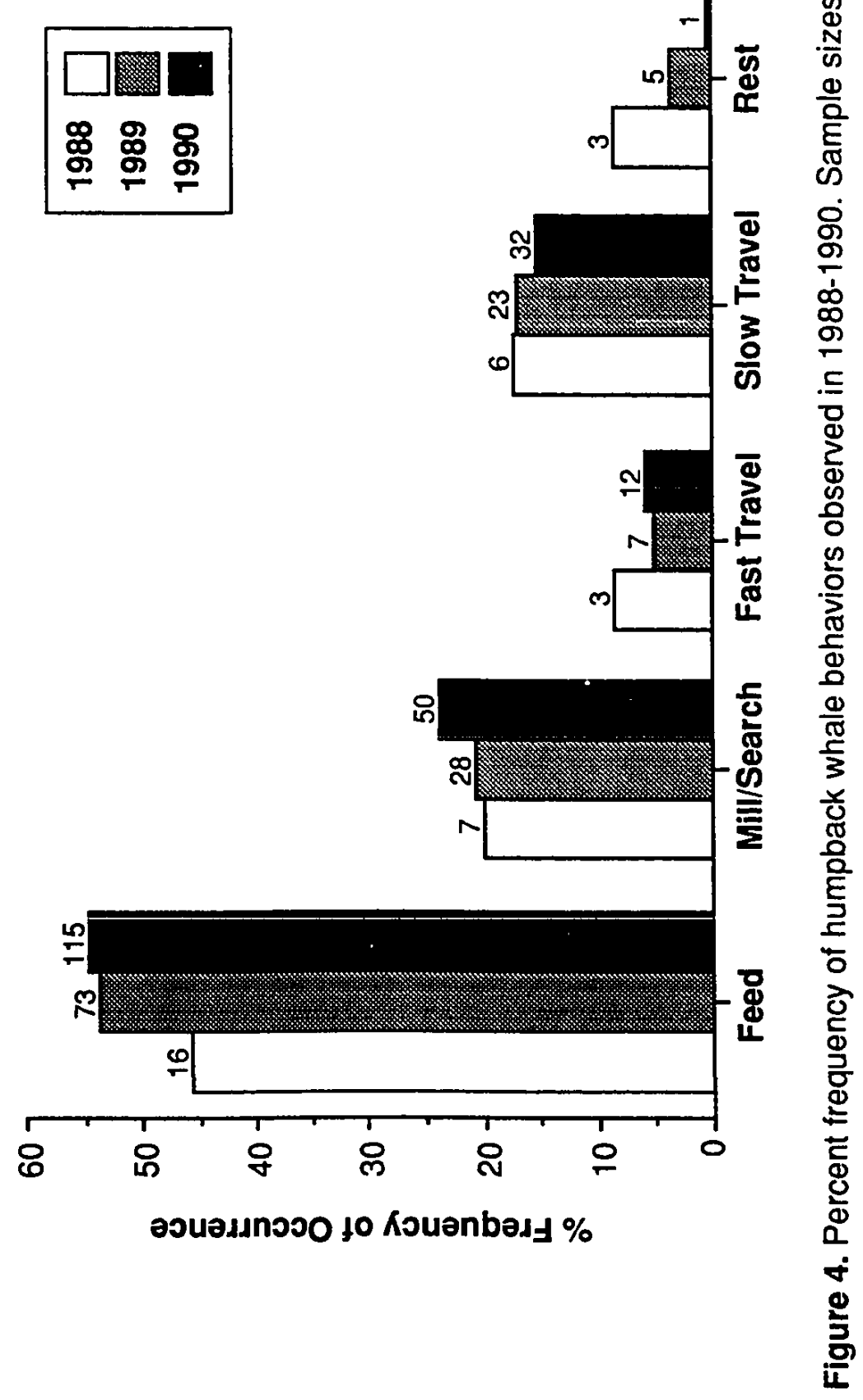




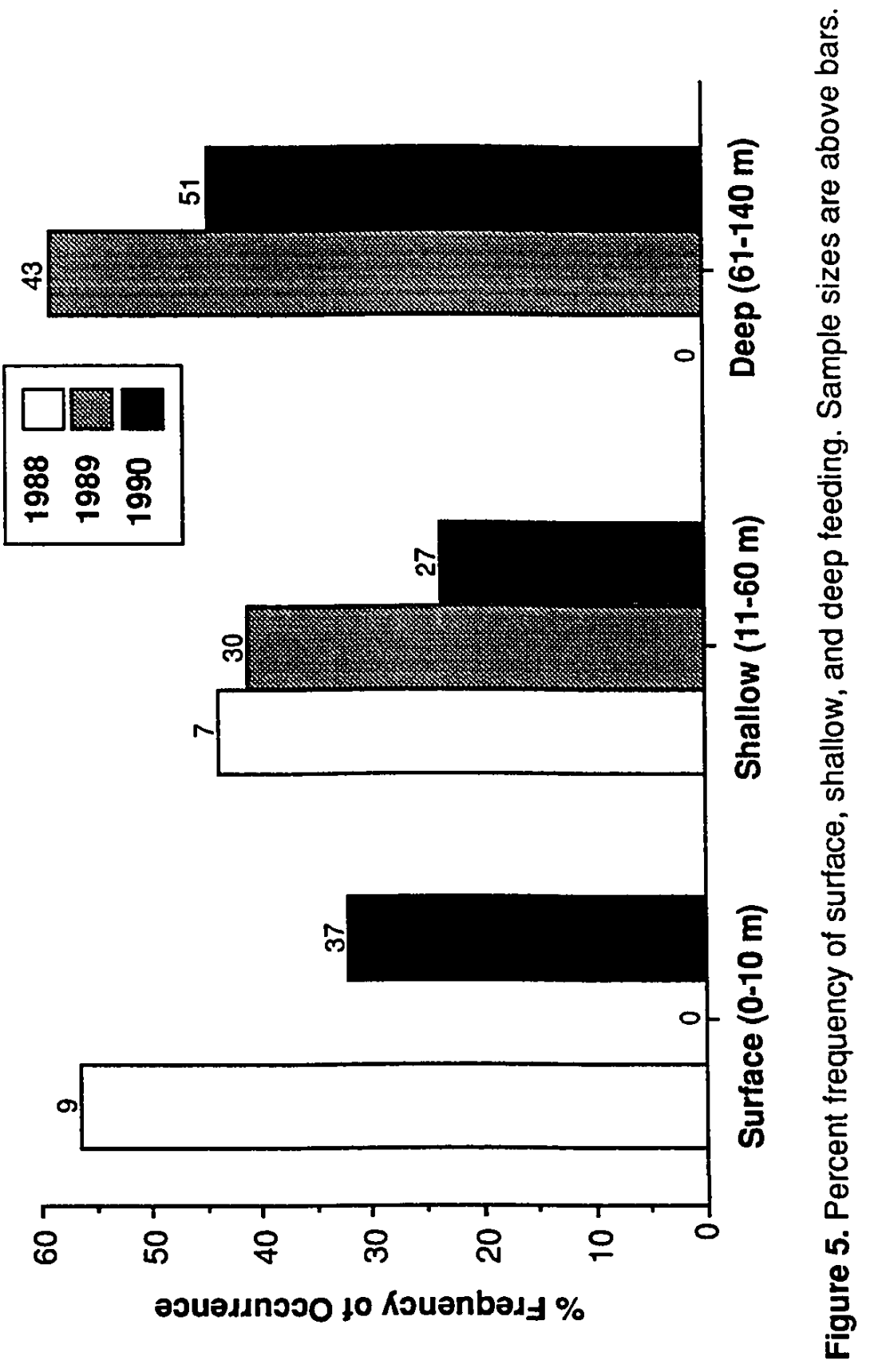




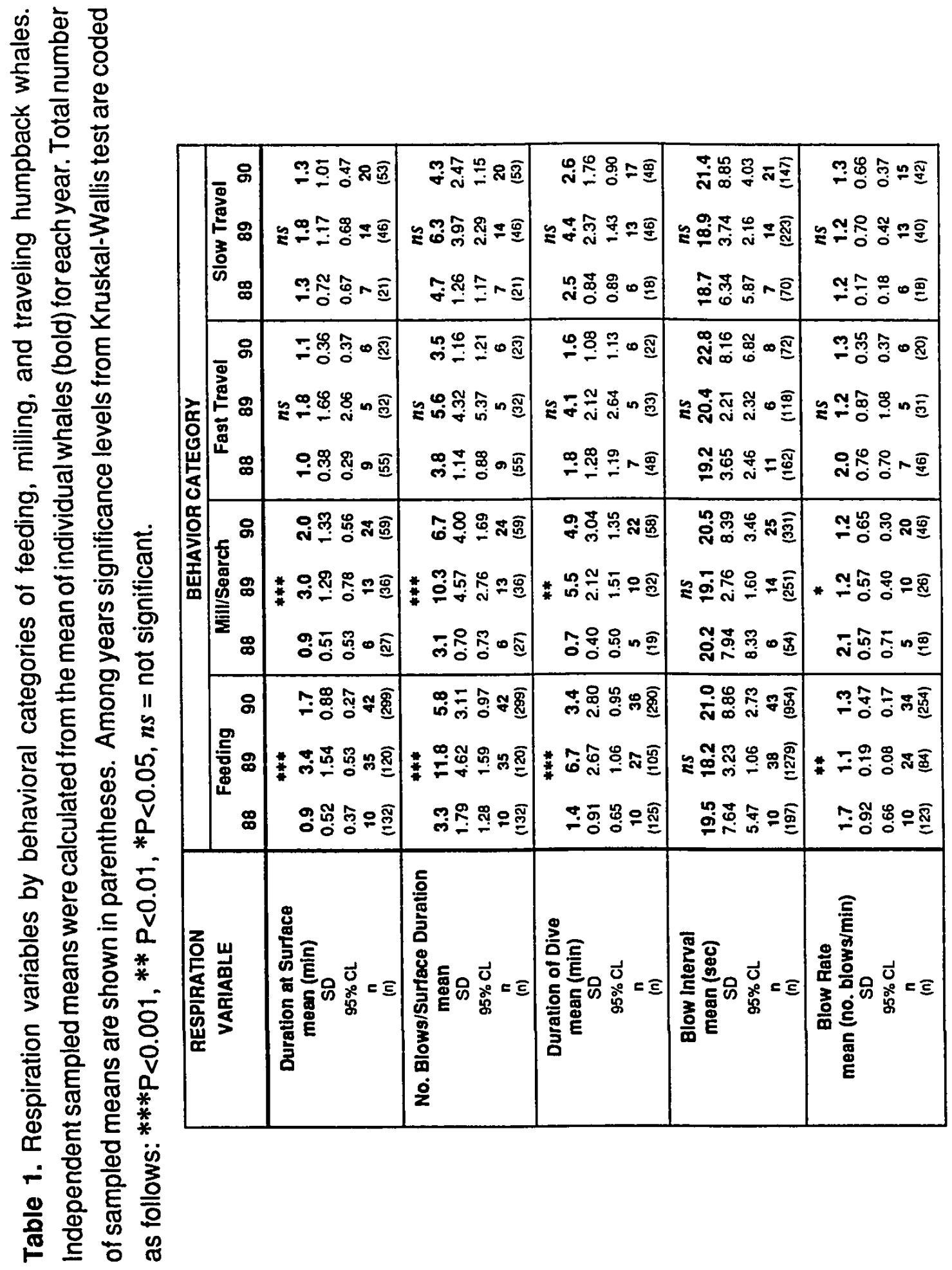




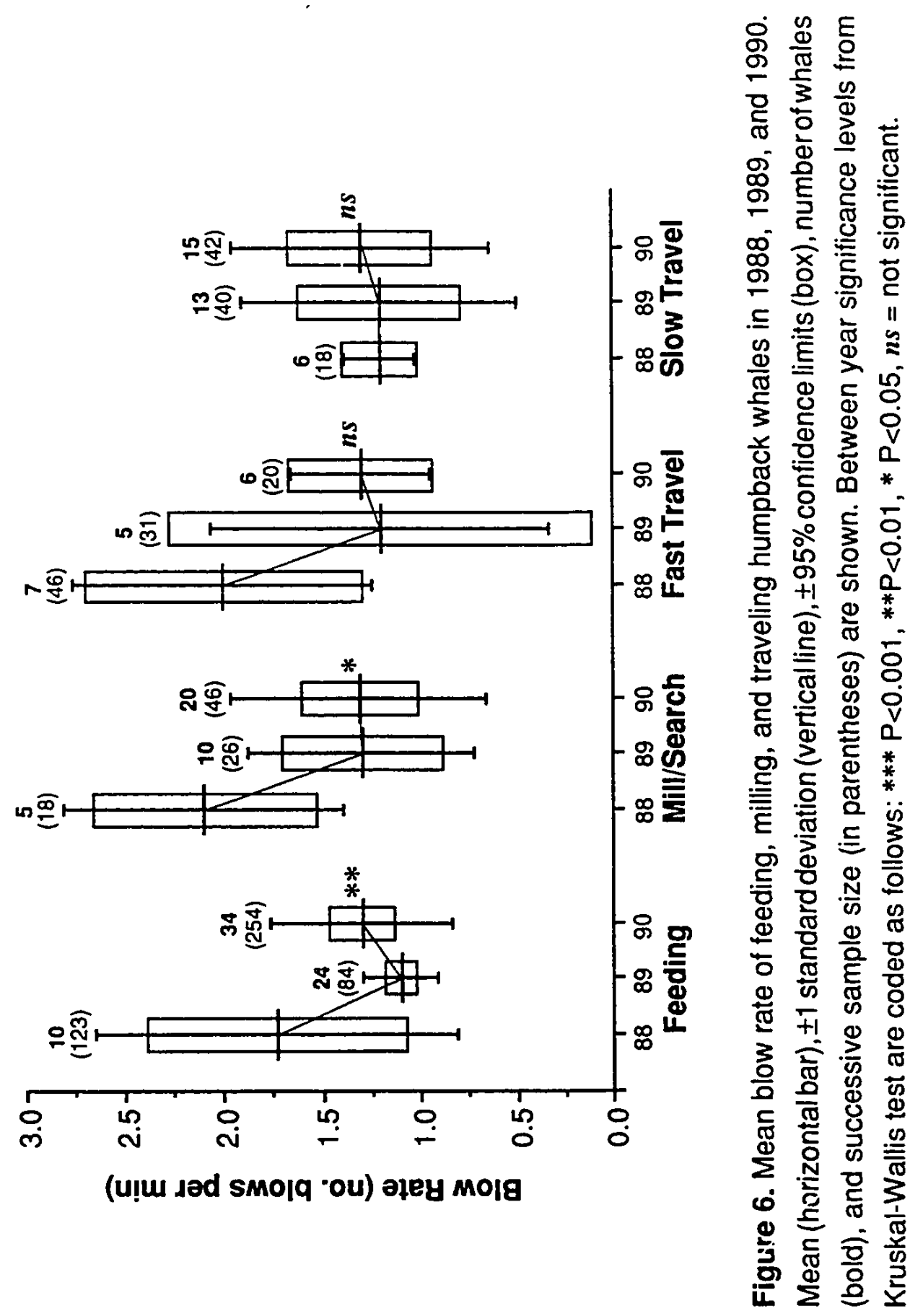


Respiratory patterns of feeding whales differed dramatically among years. The surface duration, number of blows per surface duration, and dive duration were significantly greater in 1989 than 1988 or $1990(H \geq 12.73, d f=2$, $P<0.001$; Fig. 7). These same three respiration variables were greater in 1989 than 1988 and 1990 for shallow dives (Fig. 8), but there was no difference in these variables in 1988 and 1990. Surface duration and number of blows per surface duration during deep feeding were significantly greater in 1989 than $1990(Z=2.81$ and $2.74, \mathrm{df}=\infty, P<0.01)$. Mean dive duration, however, was not significantly different between 1989 (6.3 $\mathrm{min} \pm 2.91 \mathrm{SD}$ ) and 1990 (5.9 $\mathrm{min}$ $\pm 2.31 \mathrm{SD})$. Within each year, increasing prey depth was strongly associated with increasing feeding dive duration, surface duration, and number of blows per surface duration. This relationship was best documented in 1990, the only year when feeding was recorded in all 3 depth categories $(H=12.73, H=$ 25.57, $\mathrm{H}=24.85$, respectively; $d f=2$; all $P<0.001$; Fig. 9).

Surface feeding whales typically lunged to capture prey $(92 \%$ total surfacings). They consistently performed lateral lunges ( $84 \%$ of surfacings) to capture prey more than other types of lunges (diagonal lunges $7 \%$; vertical lunges $1 \%$ ). Bubble-clouds were observed just before an executed diagonal and lateral lunge (Fig. 10). Due to variable sea conditions and observation distances exceeding $100 \mathrm{~m}$ most of the time, counts of bubble-clouds were not made consistently. 


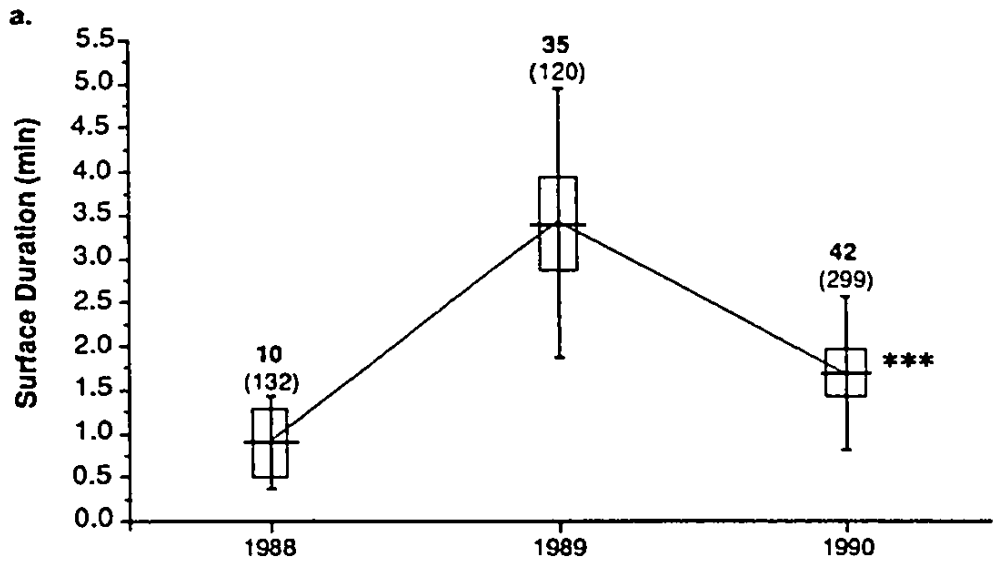

b.
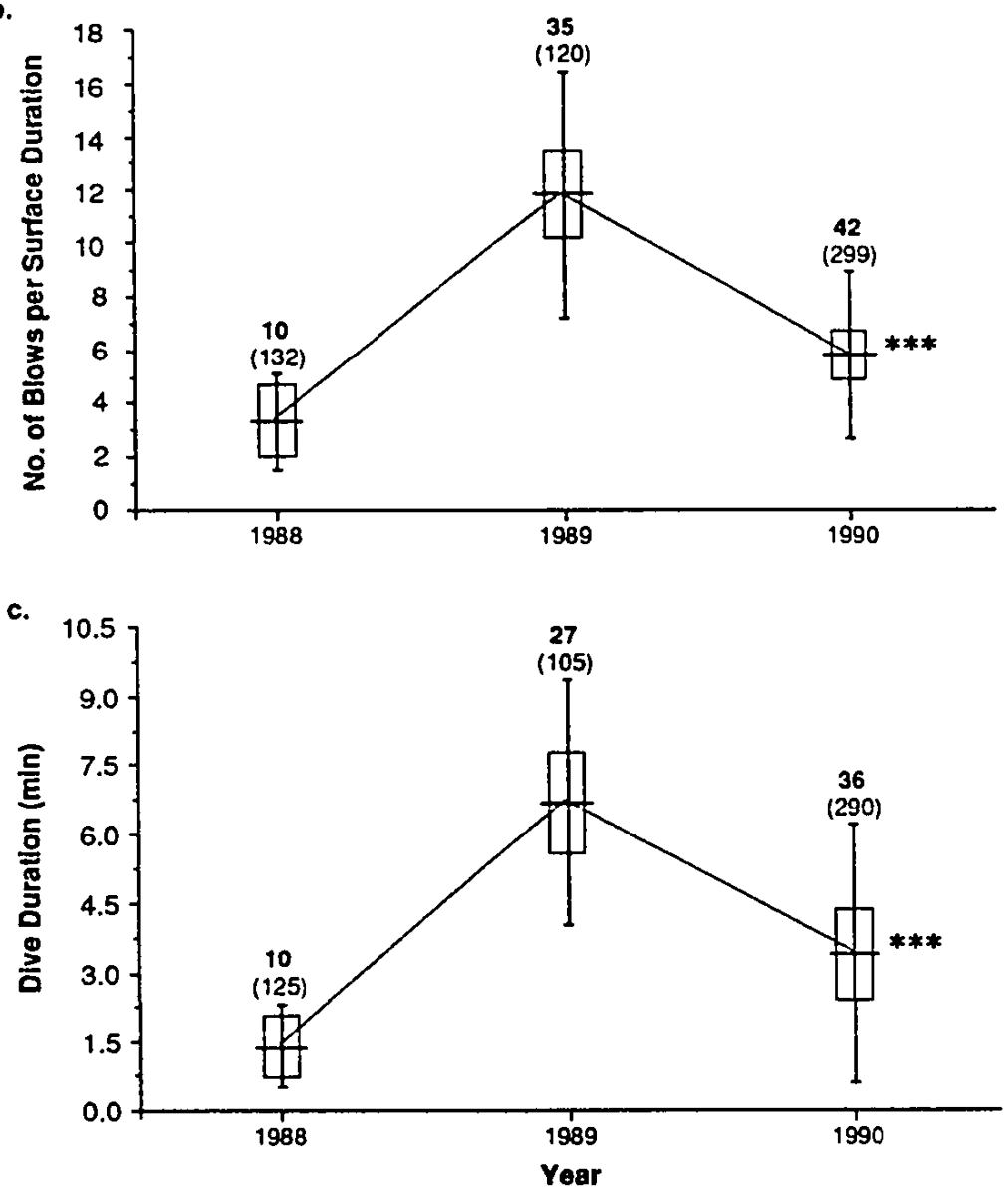

Figure 7. Surface duration, number of blows per surface duration, and dive duration in 1988, 1989, and 1990 for feeding at all depths (0-140 m). Presentation as in Figure 6. 
a.

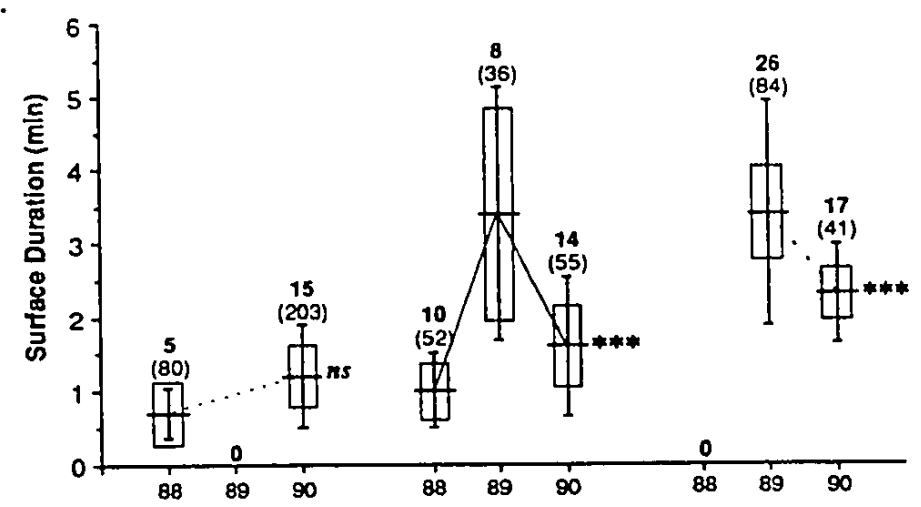

b.

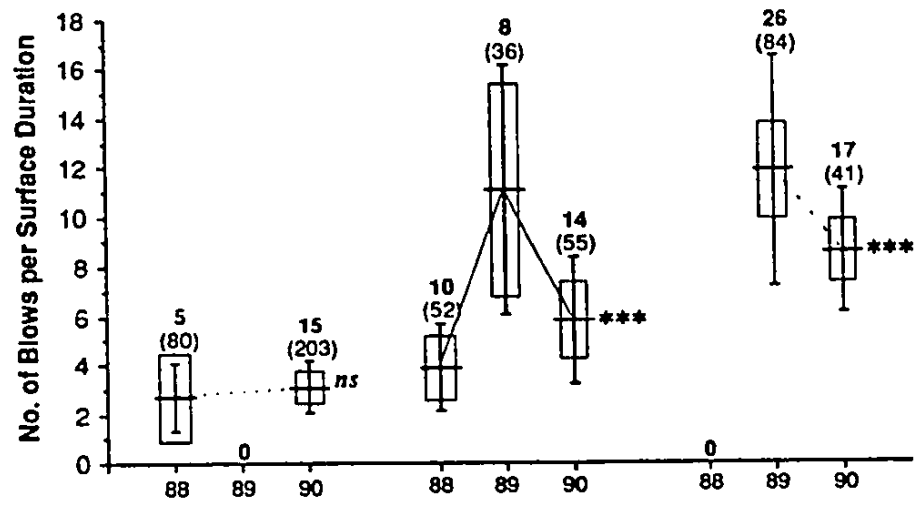

c.

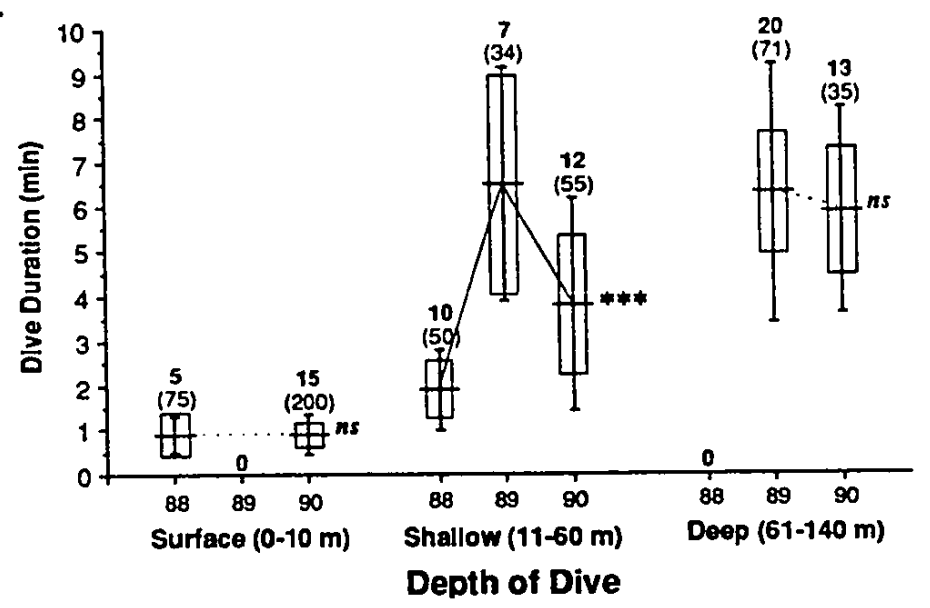

Figure 8. Surface duration, number of blows per surface duration, and dive duration of surface (0-10 m), shallow (11-60 m), deep (61-140 m) feeding, 19881990. Between year significance levels are from Kruskal-Wallis test (3 groups) and Mann-Whitney U-test (2 groups). Presentation as in Figure 6. 

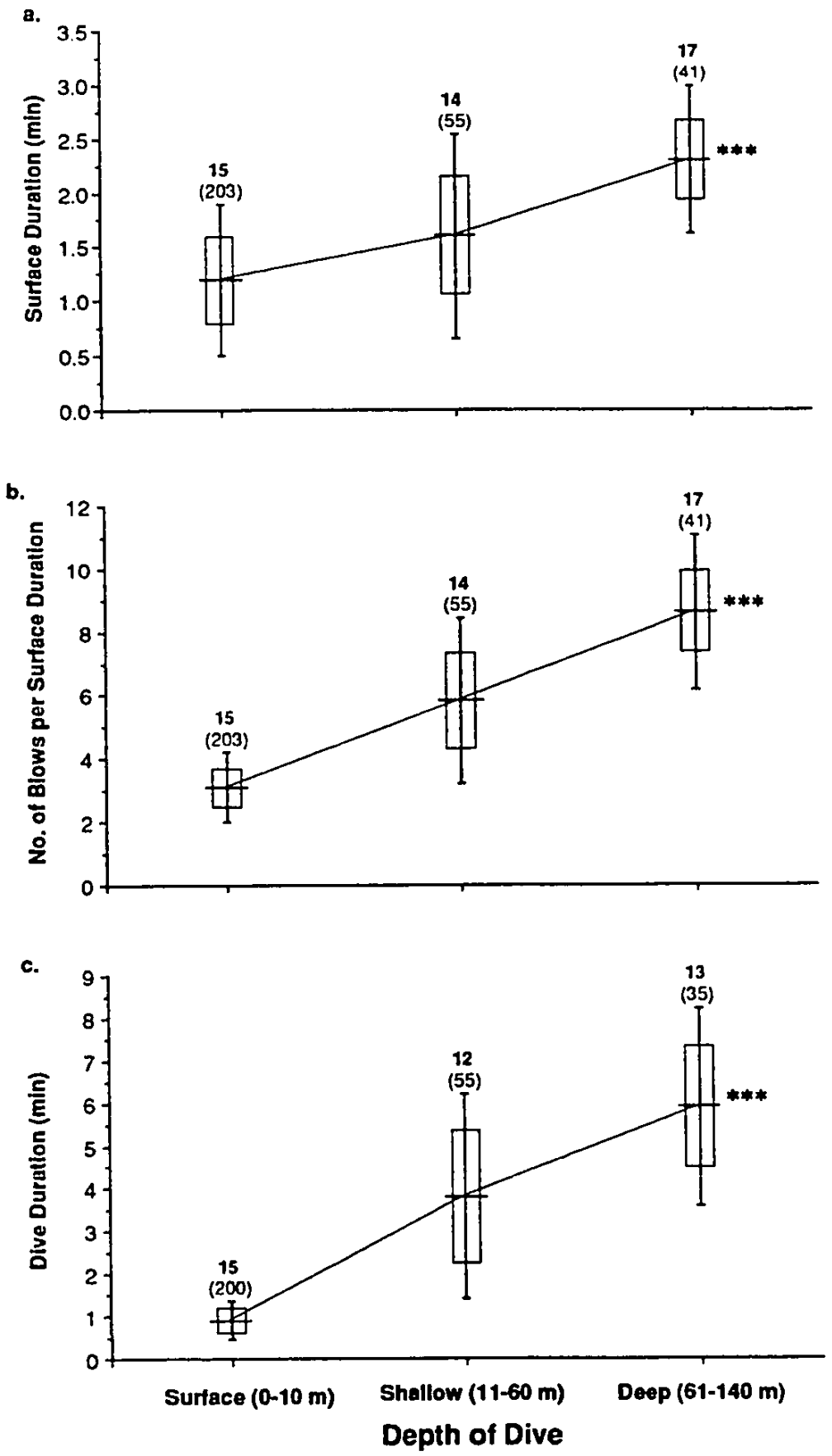

Figure 9. Surface duration, number of blows per surface duration, and dive duration of surface $(0-10 \mathrm{~m})$, shallow $(11-60 \mathrm{~m})$, deep $(61-140 \mathrm{~m})$ feeding for 1990. Between year significance levels are from Kruskal-Wallis test (3 groups). Presentation as in Figure 6. 
a.

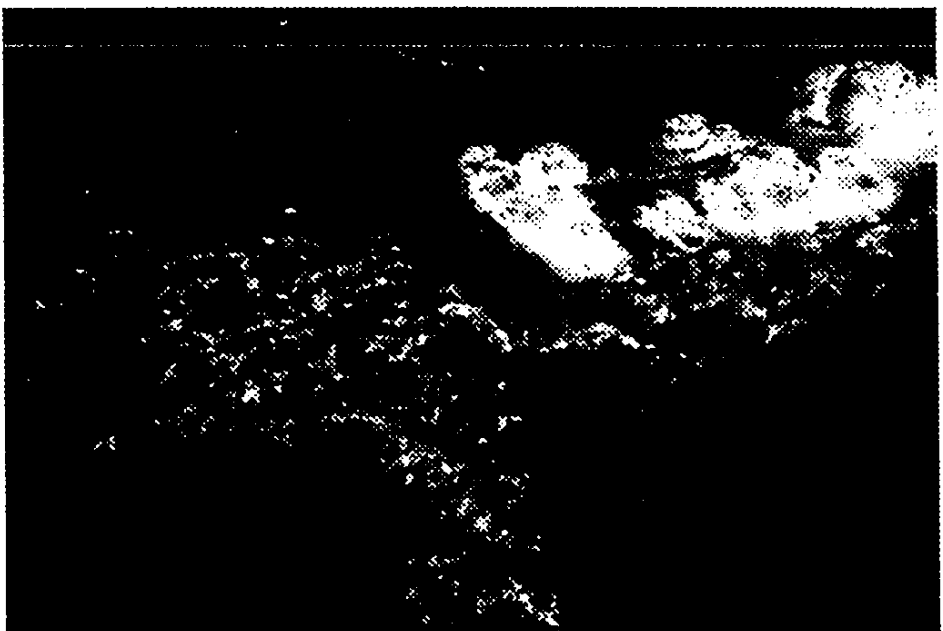

b.

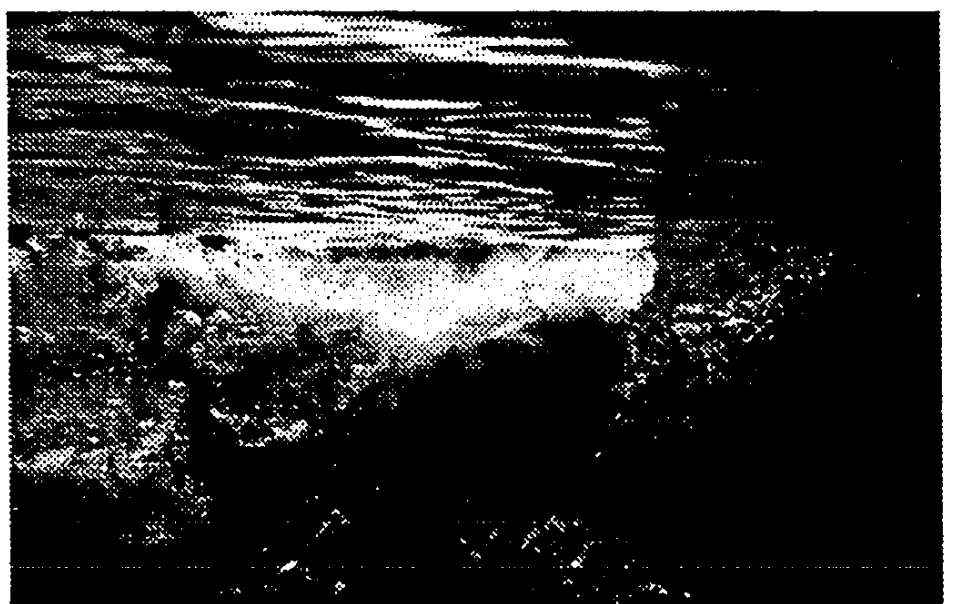

C.

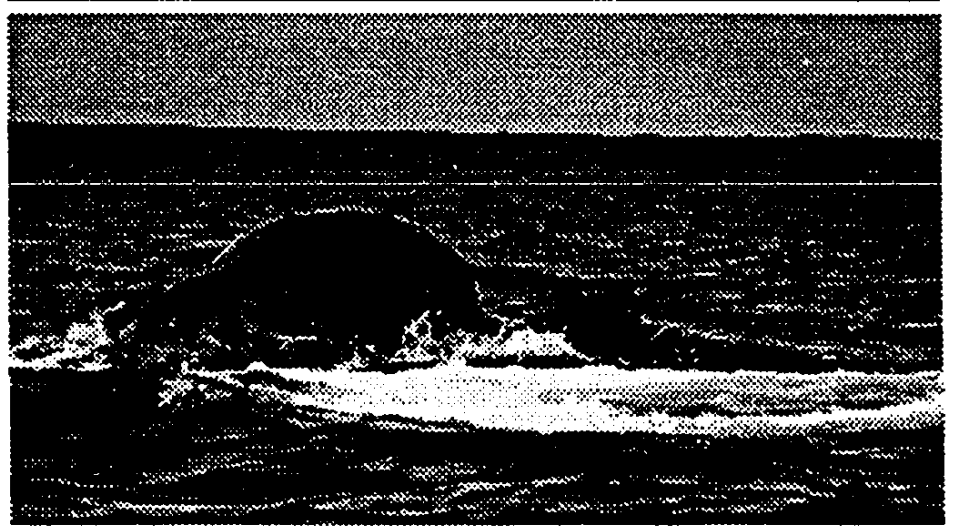

Figure 10. Humpback whale bubble-cloud formation: a) bubbles seen undenwater coming out of a whale's mouth in Hawaii,1982, b) bubbles breaking-down into tine mist (photos by author, courtesy of Kewalo Basin Marine Mammal Lab), and c) whale blowing a bubble-cloud just before a lateral lunge near Cordell Bank, California, 1990 (photo by Daniel E. Shapiro). 
Fluke-down, fluke-up, and high fluke-up behaviors preceding feeding dives were strongly correlated to prey depth $\left(X^{2}=117.13\right.$, df $=4, P<0.001$; Fig. 11). Fluke-down dives occurred most often during surface feeding ( $44 \%$ of total surface feeding dives). Fluke-up dives occurred most often during shallow feeding (67\%); high fluke-up dives were seen most often during deep feeding $(60 \%)$. Deep feeding dives were also typically preceded by a distinctive flex posture (i.e. a rolling concave stretch of the entire tail stock just before a high fluke-up dive). This flex posture preceded $77 \%$ of deep-feeding dives, and was never observed during surface or shallow feeding.

No attempt was made to record whale depth on the depth sounder. However, on seven occasions depth sounder records incidentally documented a fluke-down $\left(30^{\circ}\right)$, fluke-up $\left(50^{\circ}\right)$, and high fluke-up $\left(80^{\circ}\right)$ dive. On one occasion the entire descent $\left(75^{\circ}\right.$ angle from surface) and ascent $\left(60^{\circ}\right.$ angle to surface) of a whale travelling through a scattering layer at a mean depth of 100 $\mathrm{m}$ was recorded (Fig. 12). The duration of the dive was $4.2 \mathrm{~min}$.

In 1988-90, 32 opportunistic hydrophone recordings were made of humpback whales engaged in feeding, mill/search, and traveling (Table 2). Recordings were $15 \mathrm{~min}$ to $45 \mathrm{~min}$ in duration, totaling $12.8 \mathrm{~h}$ of recording time for the 3-year period. Feeding sounds, social sounds, and songs were qualitatively distinguished for each behavior using characteristics identified by D'Vincent et al. (1985), Silber (1986), and Payne and McVay (1971). No feeding vocalizations were recorded. Whales were quiet during all modes of feeding, except for singers recorded during deep feeding on 24 September and 8 October, 1989. 


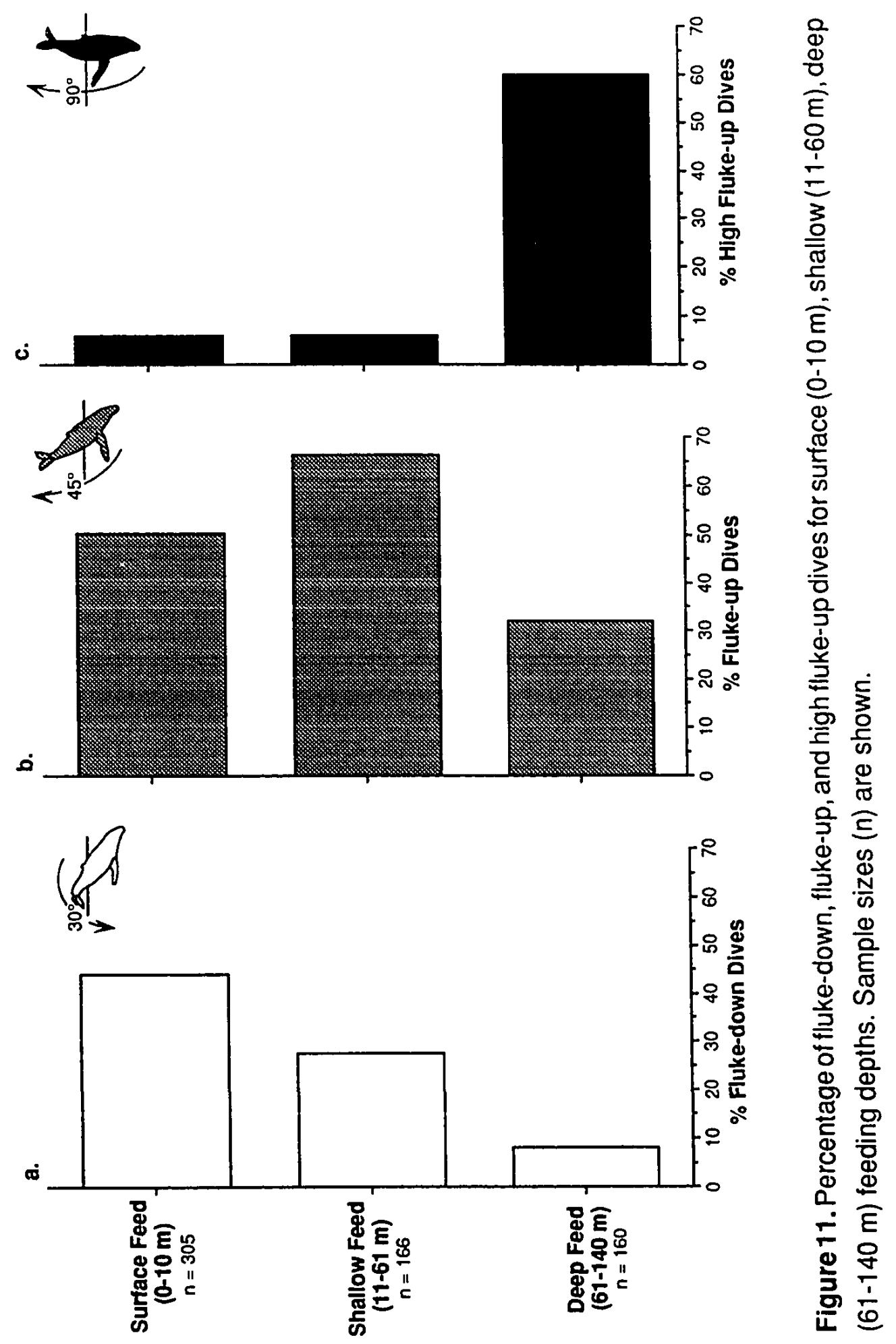


a. $30^{\circ}$ Descent

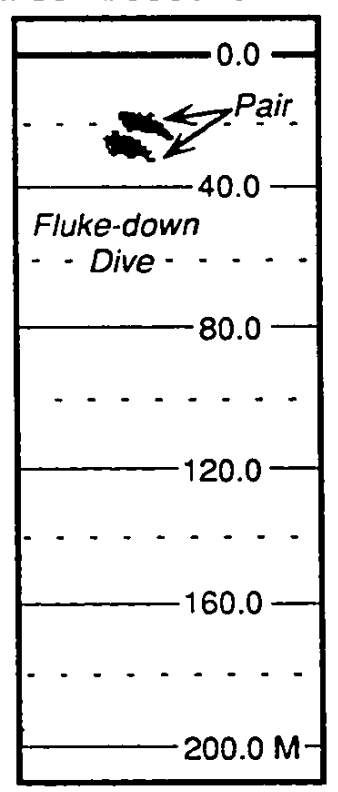

b. $50^{\circ}$ Descent

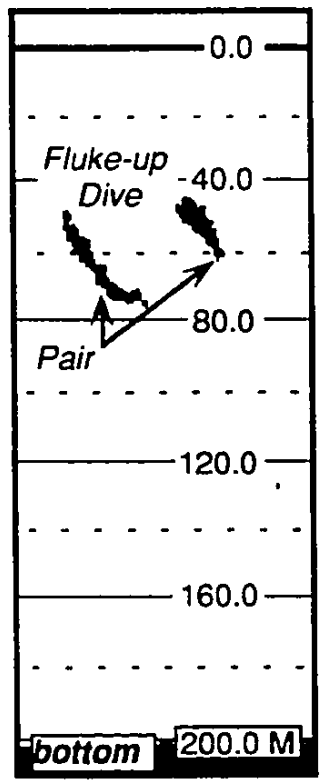

C. $80^{\circ}$ Descent

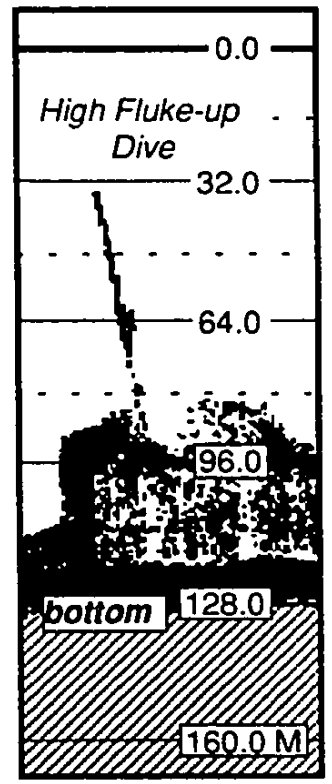

d. $75^{\circ}$ Descent and $60^{\circ}$ Ascent

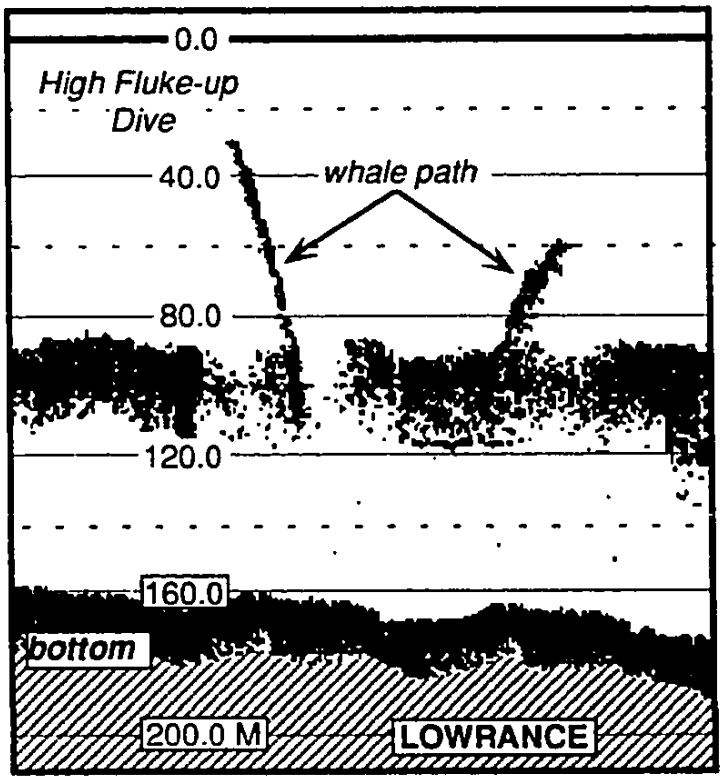

Figure 12. Depth sounder records of whales diving at (a) $30^{\circ}$ fluke-down, (b) $50^{\circ}$ fluke-up, and (c) $80^{\circ}$ high fluke-up. Bottom chart recording (d) documents an entire descent $\left(75^{\circ}\right.$ angle from surface) and ascent $\left(60^{\circ}\right.$ angle to surface) of a whale swimming through a deep scattering layer. Duration of dive was 4 min and 30 seconds. 


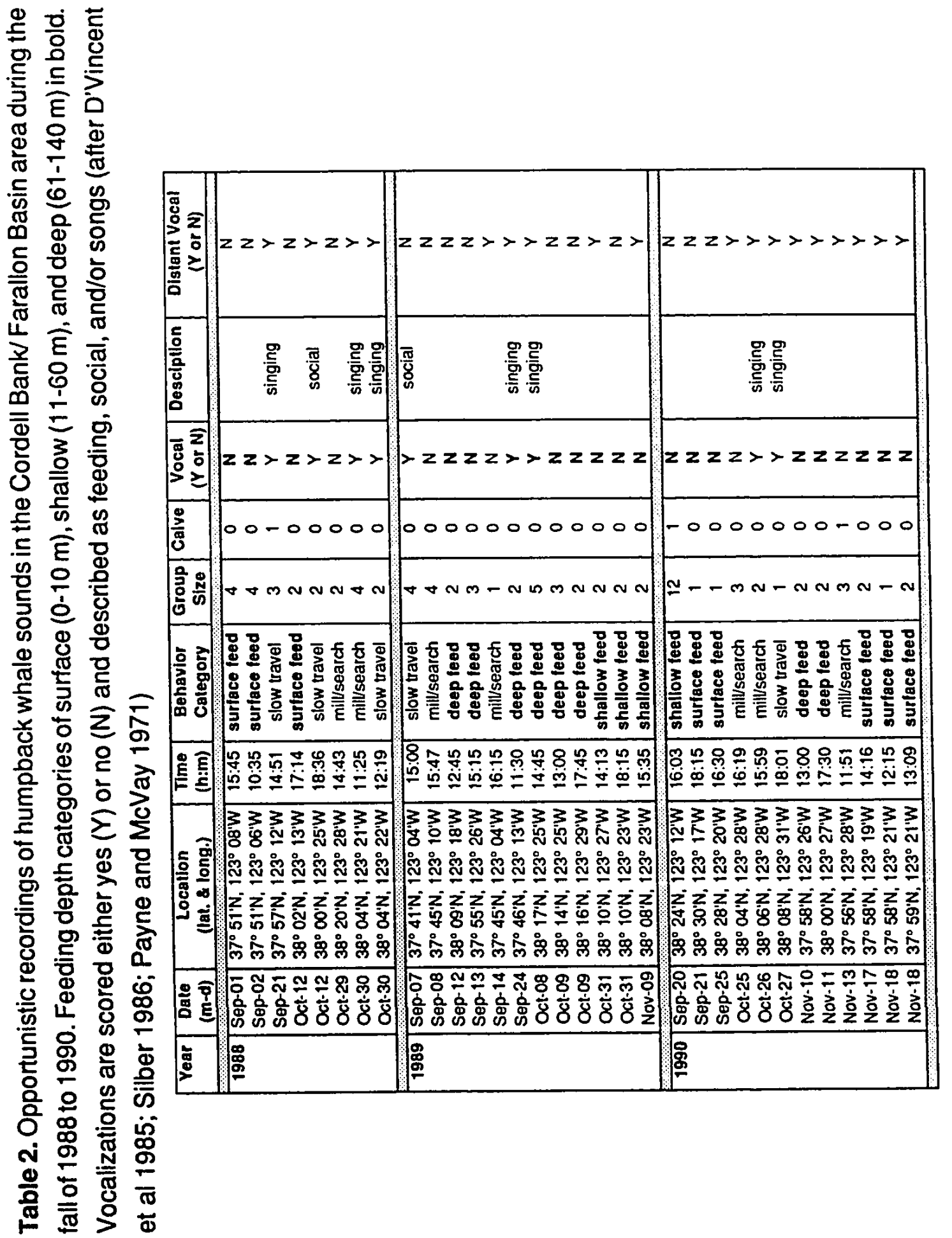


Songs of seven humpback whales were recorded: one near Point Reyes (9/21/88) and the Farallon Islands (9/24/89), two near Cordell Bank (10/30/88), and three near Bodega Canyon (10/8/89, 10/26/90, 10/27/90). Distant vocalizations (social) comprised over half $(56 \%)$ the recordings made in 198890. Songs of humpback whales were recorded earlier in 1988 (9/21) and 1989 $(9 / 24)$ than in $1990(10 / 26)$.

\section{Prey Occurrence}

In 1988 and 1990, humpback whales fed on euphausiids (primarily $T$. spinifera) and occasionally schooling fishes (primarily C. pallasii), whereas in 1989, whales were only observed feeding on euphausiids (primarily $T$. spinifera and E. pacifica). Prey of surface-feeding whales were occasionally visible from the observation boat. In 1988 and 1990, euphausiid swarms were repeatedly ( $n=17)$ seen near lunge-feeding whales. On five occasions, surface-feeding whales were observed feeding on schooling fish. These fish were tentatively identified as Pacific herring,Clupea pallasii in four feeding events and juvenile rockfish, Sebastes spp. during one feeding period. In Half Moon Bay, $40 \mathrm{~km}$ south of the study area, humpbacks were frequently reported feeding on northern anchovy (E. mordax) throughout this 3-year study (pers. comm. R. LaMar 1990).

Depth of scattering layers during September and October varied significcantly among years. Prey were consistently shallower in SeptemberOctober 1988 (13.9 $m \pm 10.97 S D, n=31)$ and $1990(27.5 m \pm 29.63$ SD, $n=38)$ than in $1989(115.2 m \pm 41.10 S D, n=87)$. A deep $(61-140 m)$ scattering layer was never recorded in 1988 , and only rarely $(14 \%, n=12)$ in 
1990. In contrast, $82 \%$ of scattering layers recorded in 1989 ( $n=31)$ occurred below $60 \mathrm{~m}$ depth (Fig. 13).

Eleven fecal samples of humpback whales were opportunistically collected in 1987 ( $n=1$; collected by Cascadia Research Collective), 1988 ( $n=2$ ), $1989(n=2)$, and $1990(n=6)$. Fecal samples contained only euphausiid hard parts. Based on right mandible counts, samples were composed of $80.6 \%$ Thysanoessa spinifera $( \pm 15.21 \mathrm{SD}, n=1848$ ) and $8.3 \%$ Euphausia pacifica ( \pm 16.41 SD, $n=291 ;$ Table 3). No evidence of fish prey (e.g. otoliths, vertebrae) were found in fecal material.

Plankton tows were consistently dominated by a single euphausiid species. In 1990, when vessel equipment allowed sampling of all three prey depths, T. spinifera comprised $98.1 \%$ of surface tows $(0-10 \mathrm{~m})$ and $87.6 \%$ of shallow tows (11-60 m). Euphausia pacifica comprised $99.6 \%$ of deep $(61-140 \mathrm{~m})$ tows. Small numbers of Nyctiphanes simplex $(1.7 \%$ and $0.4 \%)$ and Nematoscelis difficilis (1.5\%) were caught in surface and shallow tows, respectively. In 1990, $T$. spinifera were significantly larger (12.3 $\mathrm{mm} \pm 2.54 \mathrm{SD}$ ) than E. pacifica (11.4 mm $\pm 2.05 \mathrm{SD} ; \mathrm{D}=27.94, \mathrm{P}<0.001$; Fig. 14).

Mean lengths of $T$. spinifera decreased significantly from 1988 to 1990 $(D \geq 24.84, P<0.001)$. Individuals were largest in 1988 (15.9 $\mathrm{mm} \pm 2.52 \mathrm{SD}$ ), smaller in 1989 (12.8 mm $\pm 1.34 \mathrm{SD}$ ) and smallest in 1990 (12.3 mm $\pm 2.54 \mathrm{SD}$; Fig. 15).

Calculated standard body lengths of $T$. spinifera and $E$. pacifica in fecal samples were longer than those caught in tow samples. Calculations were based on linear regressions of body length to mandible length from tow samples (Fig. 16). 
a.

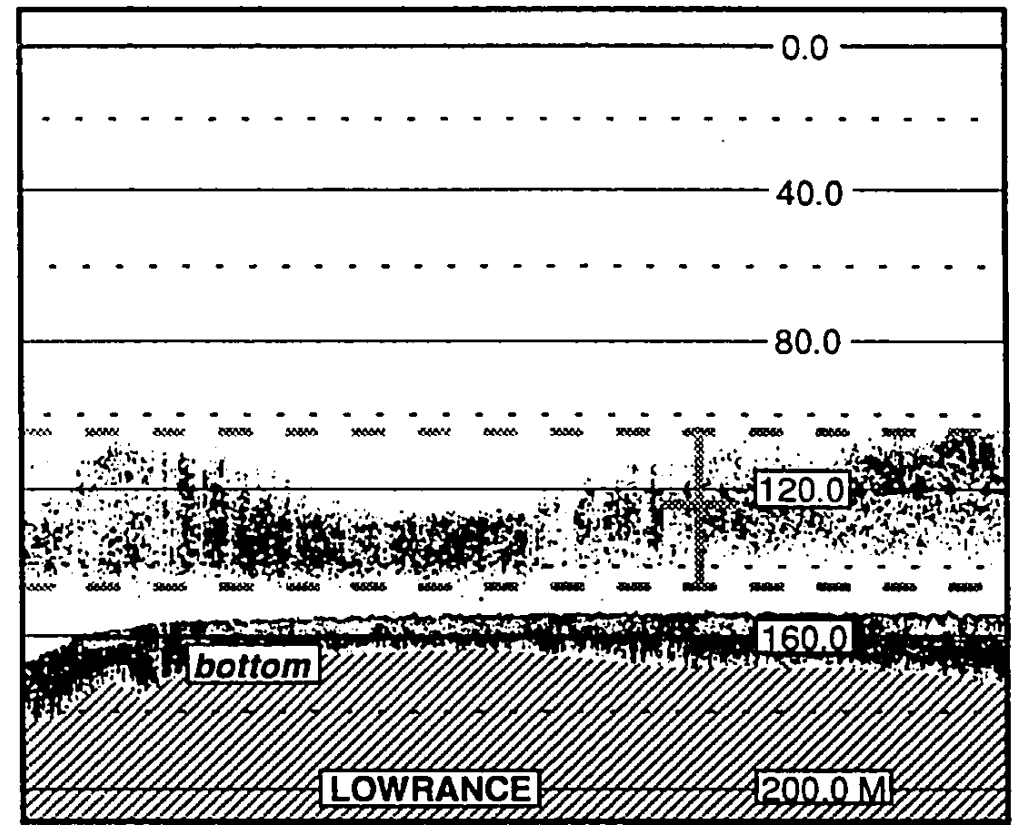

b.

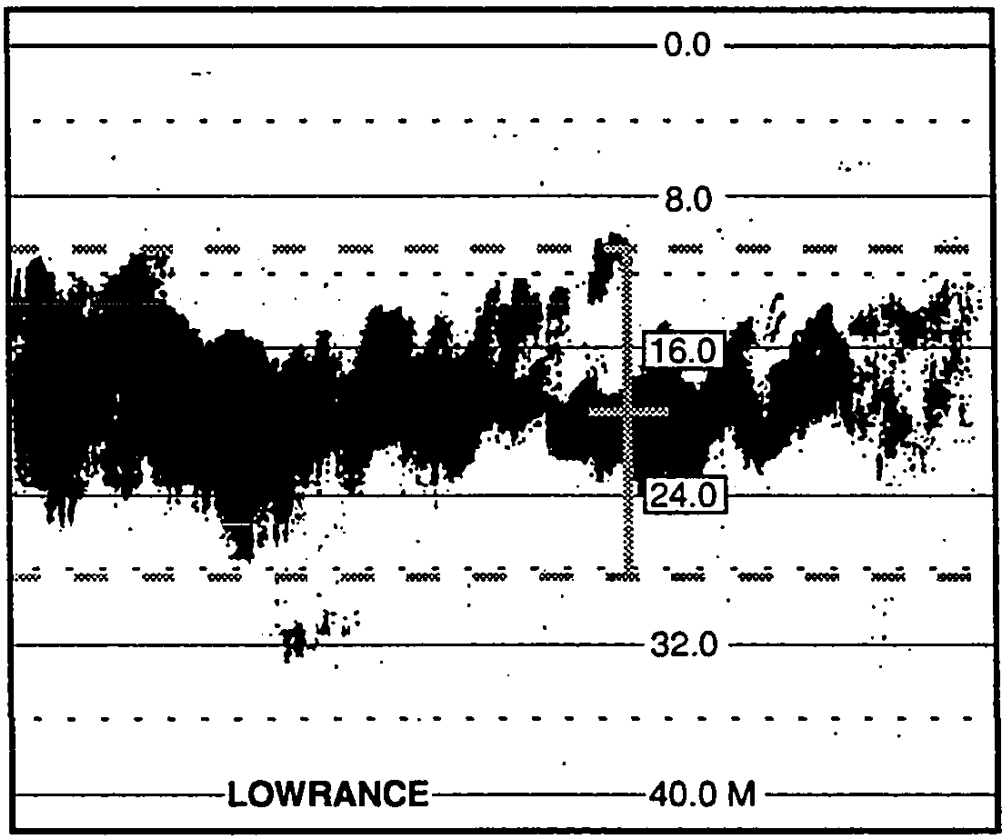

Figure 13. Depth sounder records documenting (a) deep scattering layer with a mean depth of $124 \mathrm{~m}$ on September 8, 1989 and (b) shallow scattering layer with a mean depth of 19 m on October 31, 1989, which only occurred later in the 1989 season. 
Table 3. Humpback whale fecal samples $(n=11)$ collected in the study area during the fall of 1987 to 1990 . Right mandibles and spermatophores were identified for each species and counted from a $10 \mathrm{ml}$ aliquot. Sample sizes (in parentheses) and \pm 1 standard deviations of the grand mean are shown.

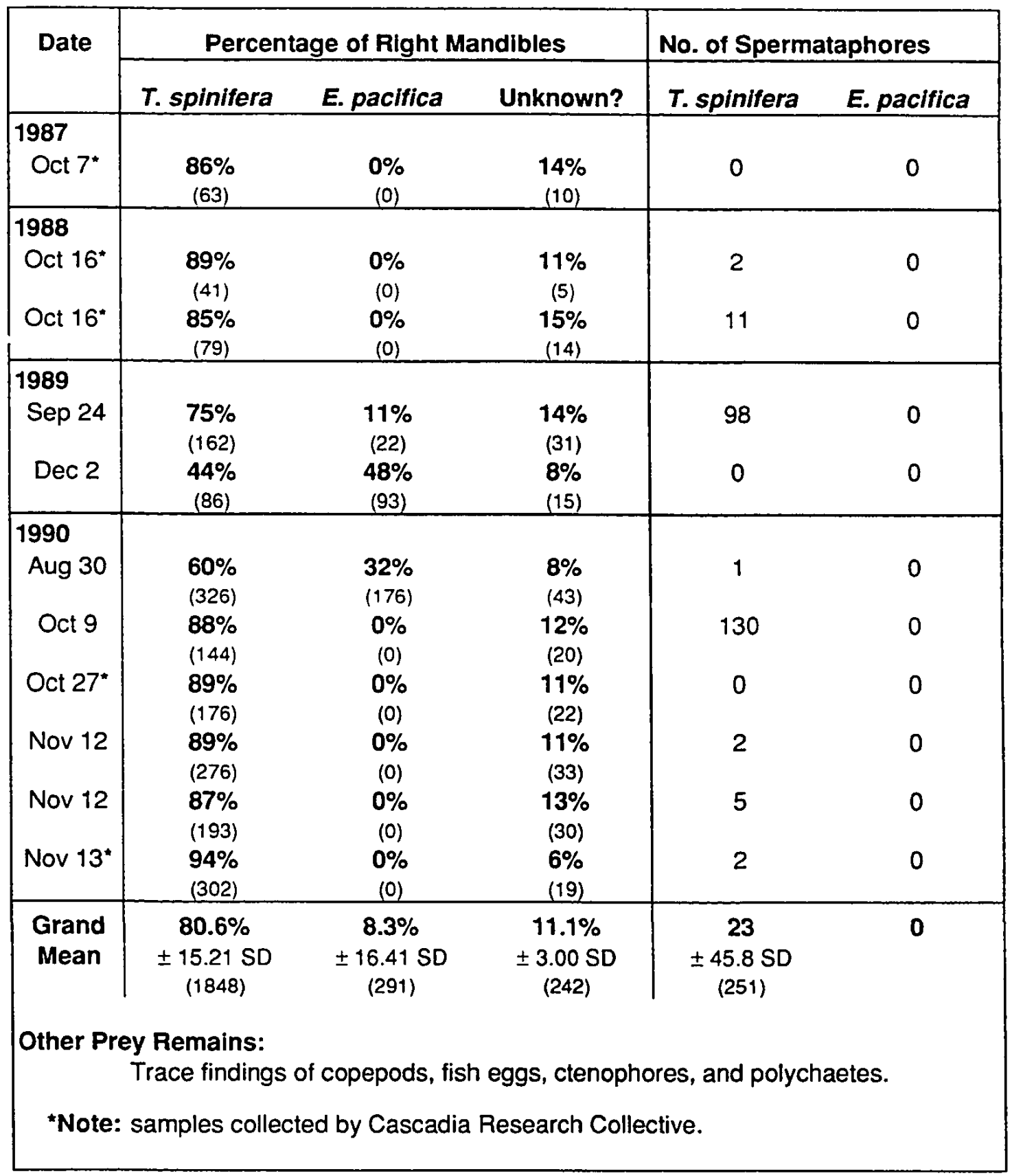




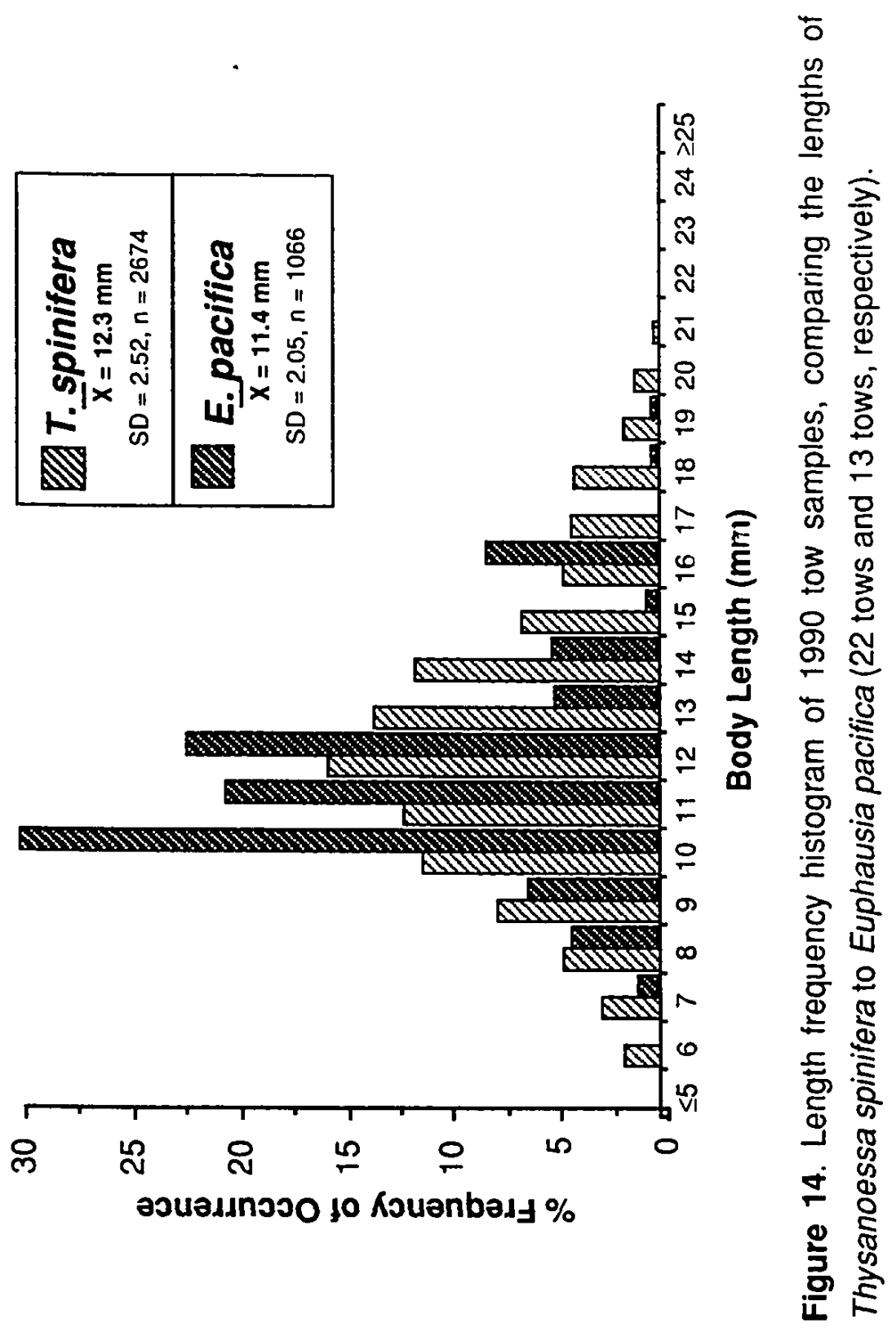



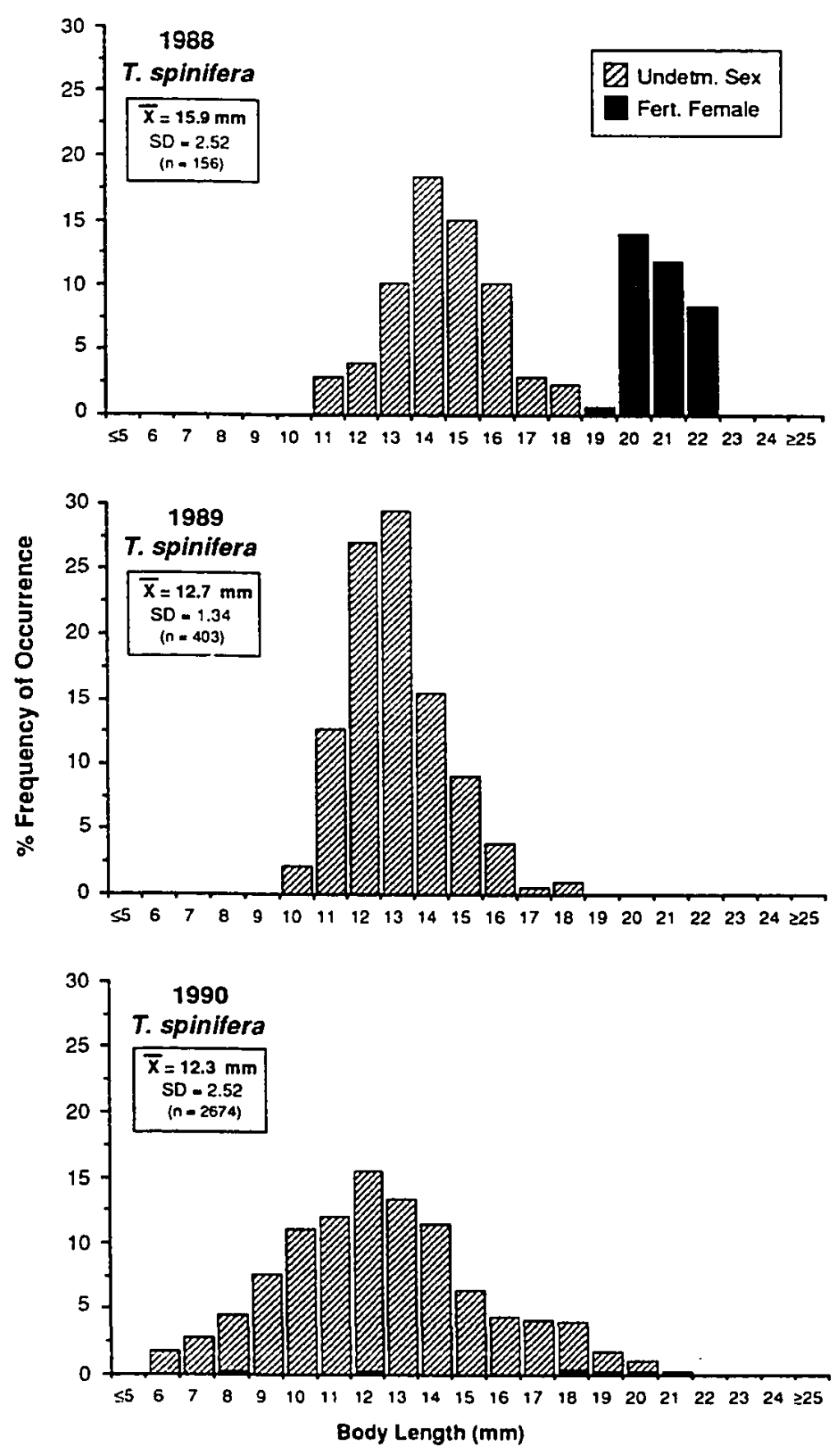

Figure 15. Length trequency of Thysanoessa spinifera caught in tows for 1988, 1989 , and 1990 (4, 3, and 22 tows, respectively). Fertilized females (black) were distinguished by the presence of transferred spermatophore packets. 


\section{a. Thysanoessa spinifera}

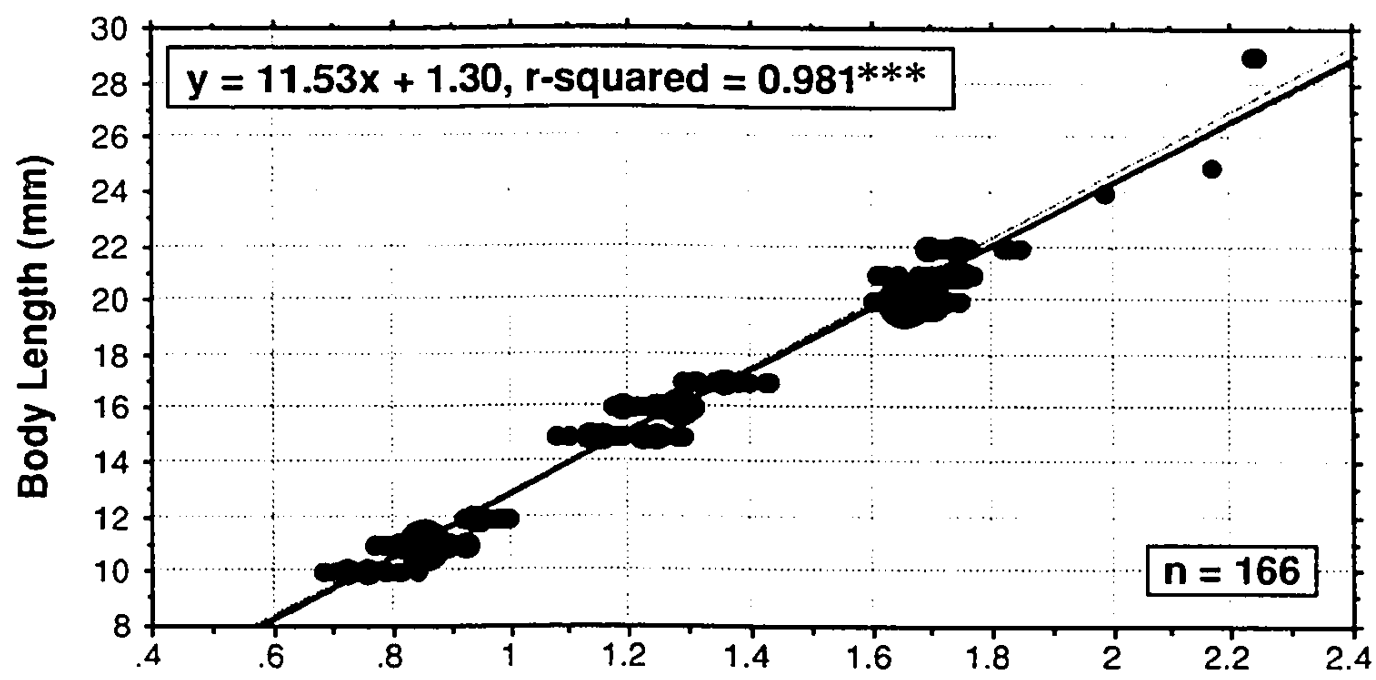

b. Euphausia pacifica

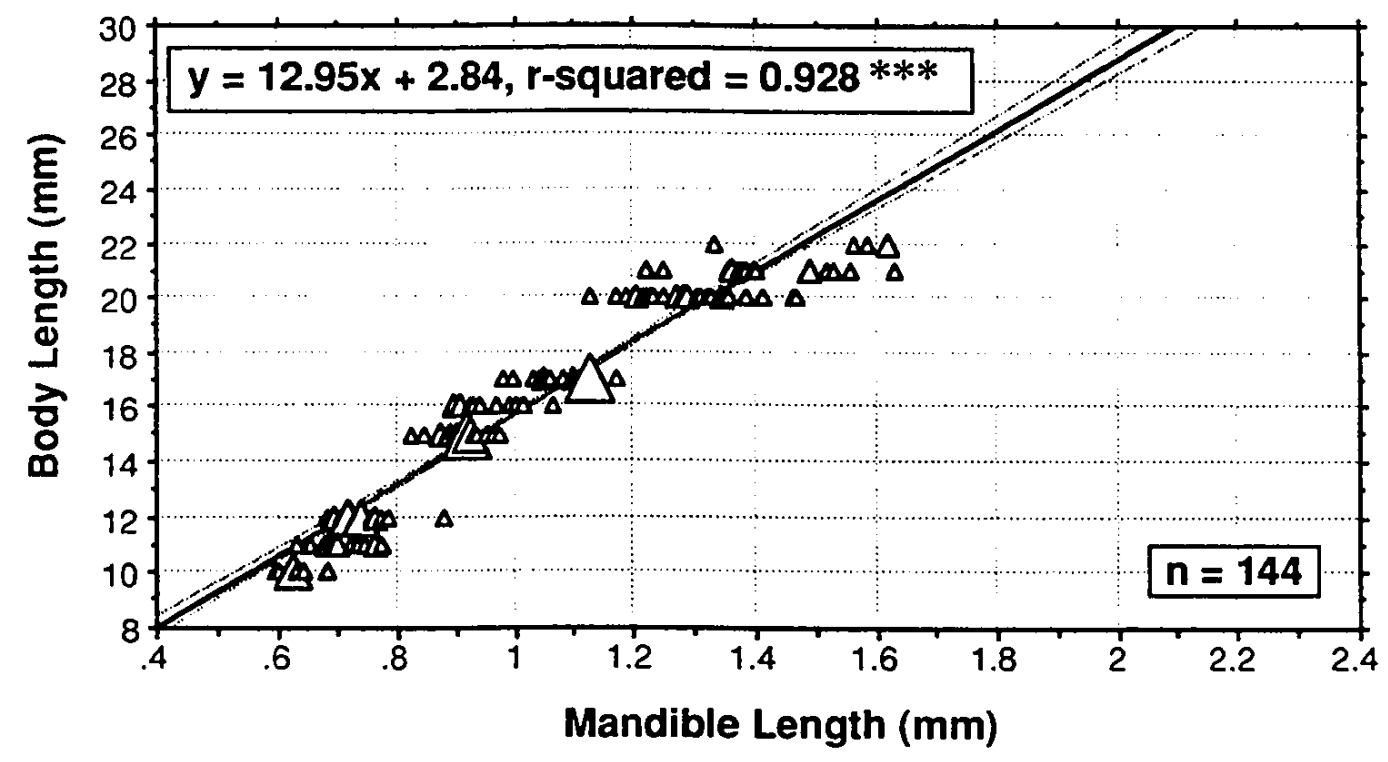

Figure 16. Linear regressions of standard body length versus right mandible length of Thysanoessa spinifera and Euphausia pacifica. Equations, 95\% confidence limits for the slope of regression line, and significant levels of*** $\mathrm{P}<0.001$ are shown. 
Mean body lengths ( \pm SD) of $T$. spinifera in fecal samples were $16.0 \mathrm{~mm}( \pm 1.81)$ in $1988,16.7 \mathrm{~mm}( \pm 2.19)$ in 1989 , and $16.2 \mathrm{~mm}( \pm 1.88)$ in 1990. Euphausia pacifica had a mean body length of $16.1 \mathrm{~mm}( \pm 2.16)$ in 1989 and $16.0 \mathrm{~mm}$ $( \pm 2.58)$ in 1990 (Fig. 17).

There was a greater percentage of fertilized female euphausiids in the plankton tows for 1988 (34.5\%) than 1989 (0\%) and 1990 (1.1\%; Fig. 15). Thysanoessa spinifera spermatophores were identified in fecal samples each year; the highest number occurred in 1989 (96 on 24 Sep) and 1990 (130 on 9 Oct; Table 3).

In 1990, T. spinifera were most of the biomass collected in surface and shallow plankton tows (grand mean $=92.8 \% \pm 7.35 \mathrm{SD}$ ), whereas $E$. pacifica accounted for $99.6 \% \pm 0.64 \mathrm{SD}$ of the biomass in deep tows (Table 4). Nyctiphanes simplex and $N$. difficilis occurred rarely and only in surface and shallow tows (grand mean $=1.1 \% \pm 0.92 \mathrm{SD}$ and $0.8 \% \pm 1.06 \mathrm{SD}$, respectively). The occurrence of 3 species of planktivores, Cassin's auklet (Ptychoramphus aleuticus), Red Phalaropes (Phalaropus fulicaria), and Red-necked Phalaropes ( $P$. lobatus), were closely correlated with the presence of surface and nearsurface scattering layers (Fig. 18).

\section{Environmental Data \& Red Tide}

Daily mean scattering layer depths and corresponding environmental factors when whales were present were measured less frequently in 1989 than 1990 (18 and 32 days, respectively). For 1989 and 1990, the daily surface temperature, Secchi depth, Beaufort state, and bottom depth were highly variable compared to the distribution of scattering layer depths (Fig. 19). 

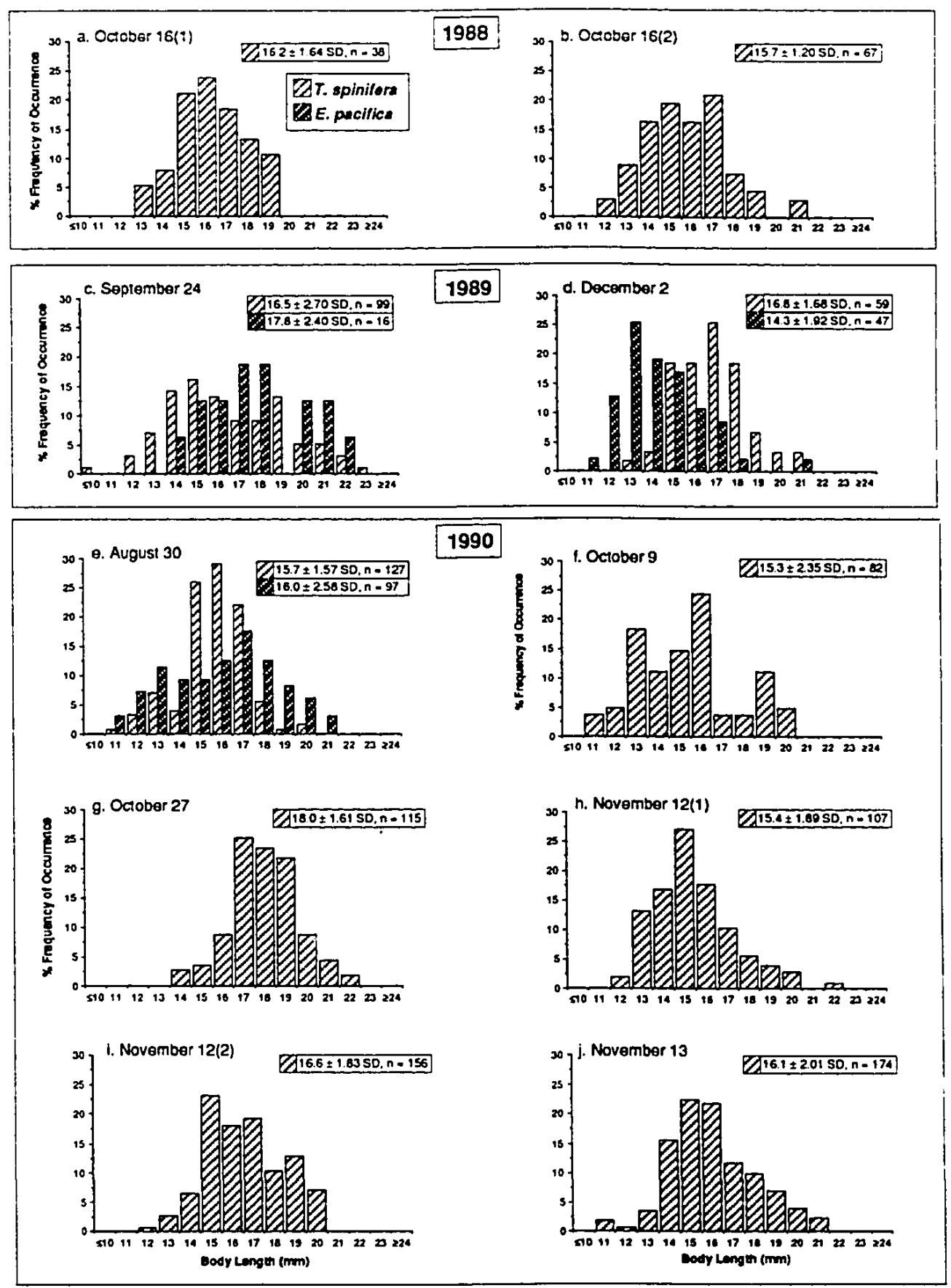

Figure 17. Calculated standard body length frequencies for Thysanoessa spinifera and Euphausia pacifica from right mandibles collected in humpback whale fecal samples, 1988-90. Mean, \pm 1 standard deviation, and sample size (n) for each species and sample are shown. 


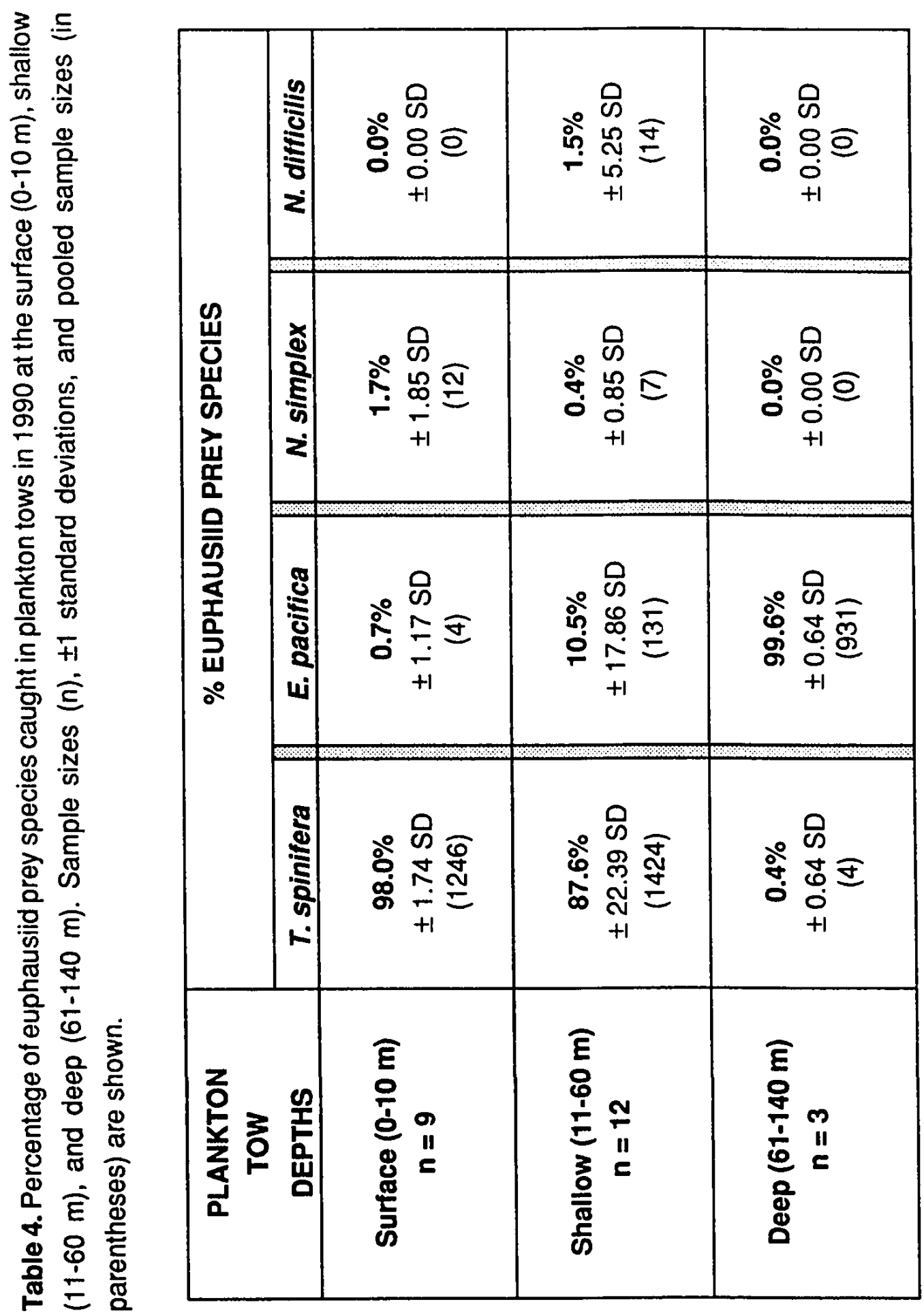




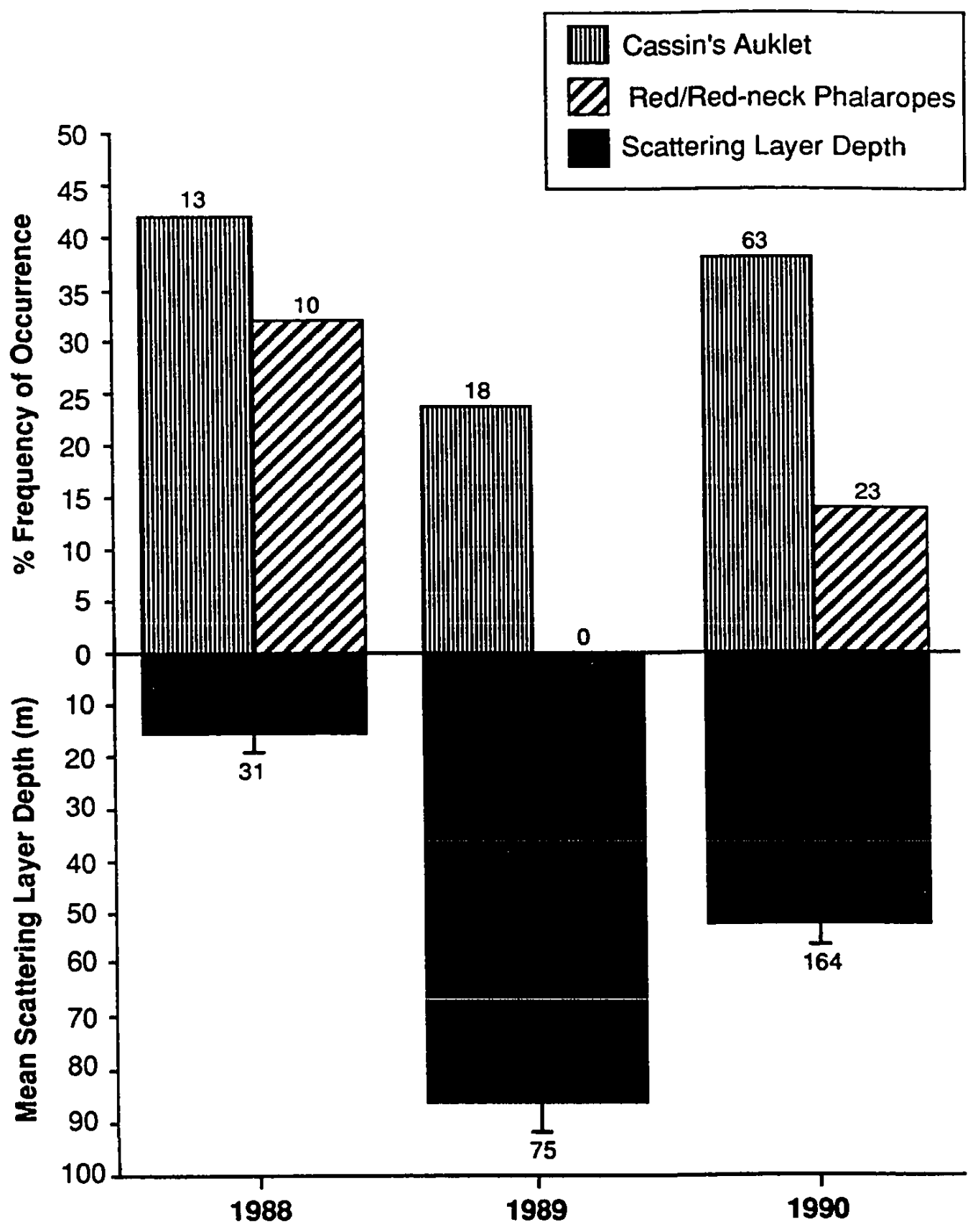

Figure 18. Percent frequency of occurrence of Cassin's auklet and Phalarope observed relative to mean prey depth for 1988,1989 , and 1990 . Standard errors (lines below bars) and sample sizes are shown. 


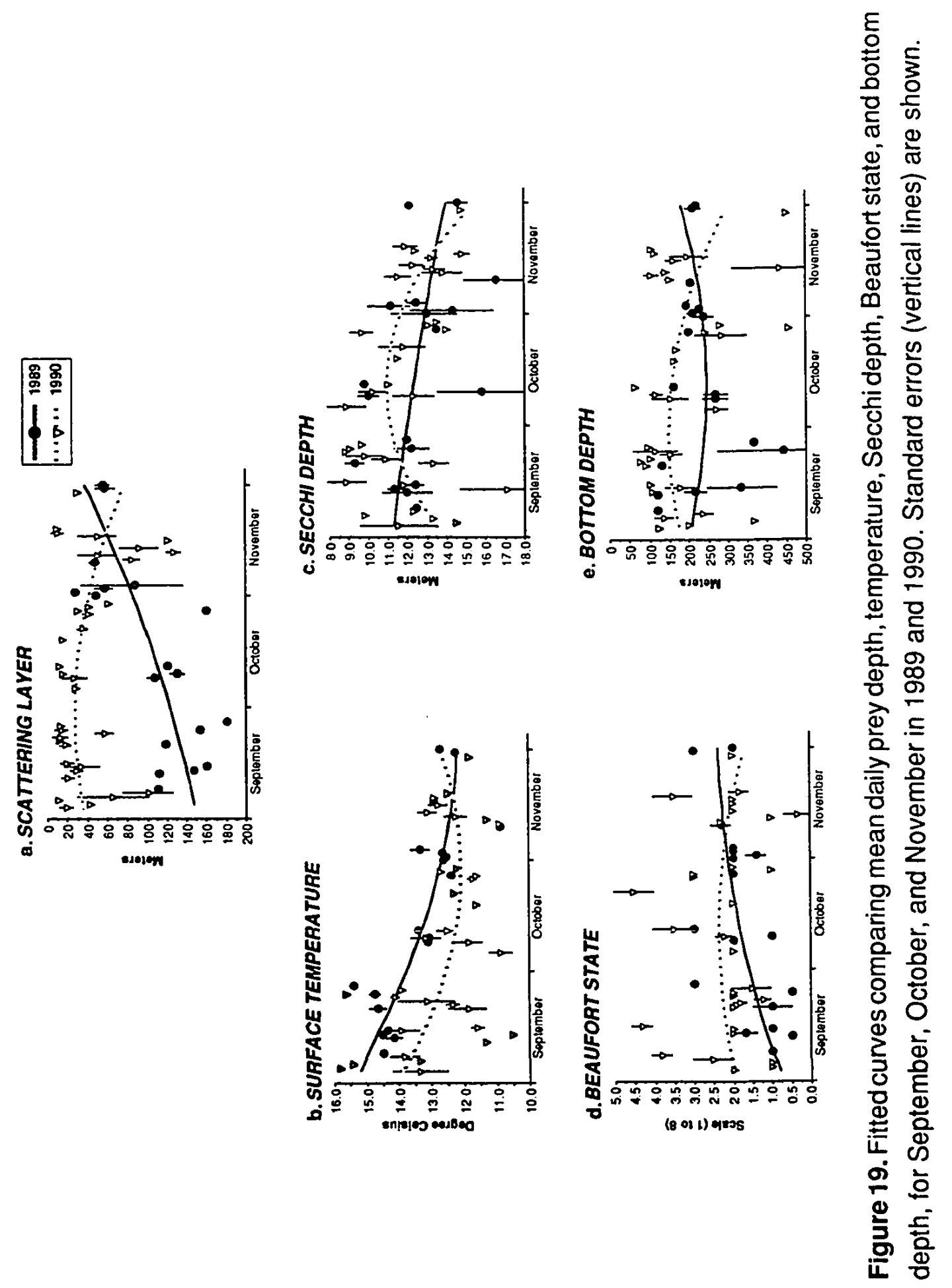


in 1989, daily mean depth of the scattering layer was greater than in 1990 during September and October. In 1989 and 1990, surface temperatures declined throughout the study period. Secchi depth increased in 1989, and visibility improved during the 3-month studiy pariod. However, in 1990, water visibility fluctuated from relatively clear to turbid waters by mid-October and back to clearer waters again by the end of November. Beaufort state increased during the study period in 1989 , but remained the same in 1990. Daily mean bottom depths where humpback whales fed were highly variable for both years, but fitted curves yielded equivalent depths throughout the study period $(t=1.889, d f=48, P<0.01)$.

The greatest difference in depth of scattering layer between 1989 and 1990 occurred during September. During September, the mean surface temperature in $1989\left(14.6^{\circ} \mathrm{C} \pm 0.39 \mathrm{SD}\right)$ was greater than in $1990\left(13.3^{\circ} \mathrm{C} \pm\right.$ 1.64 SD), whereas Beaufort state (1.5 $\pm 0.71 \mathrm{SD}$ and $2.3 \pm 1.21 \mathrm{SD}$, respectively) and secchi depth (11.7 $\mathrm{m} \pm 1.12 \mathrm{SD}$ and $12.5 \mathrm{~m} \pm 3.83 \mathrm{SD}$, respectively) were less.

In 1989, only surface temperature was significantly related with scattering layer depth (stepwise regression, $F=17.5, d f=17, p<0.001$ ), where greater surface temperatures corresponded closely to greater depths of the scattering layer $\left(r^{2}=0.52\right.$; Fig. 20). Other variables were not related to prey depth in 1989 or 1990. However, in 1990, daily mean Beaufort states were greater and more variable than in 1989, resulting in more wind-induced mixing of subsurface waters. Lower mean surface temperature and secchi depths recorded during 1990 were a reflection of periodic upwelling events. 


\section{a. 1989}

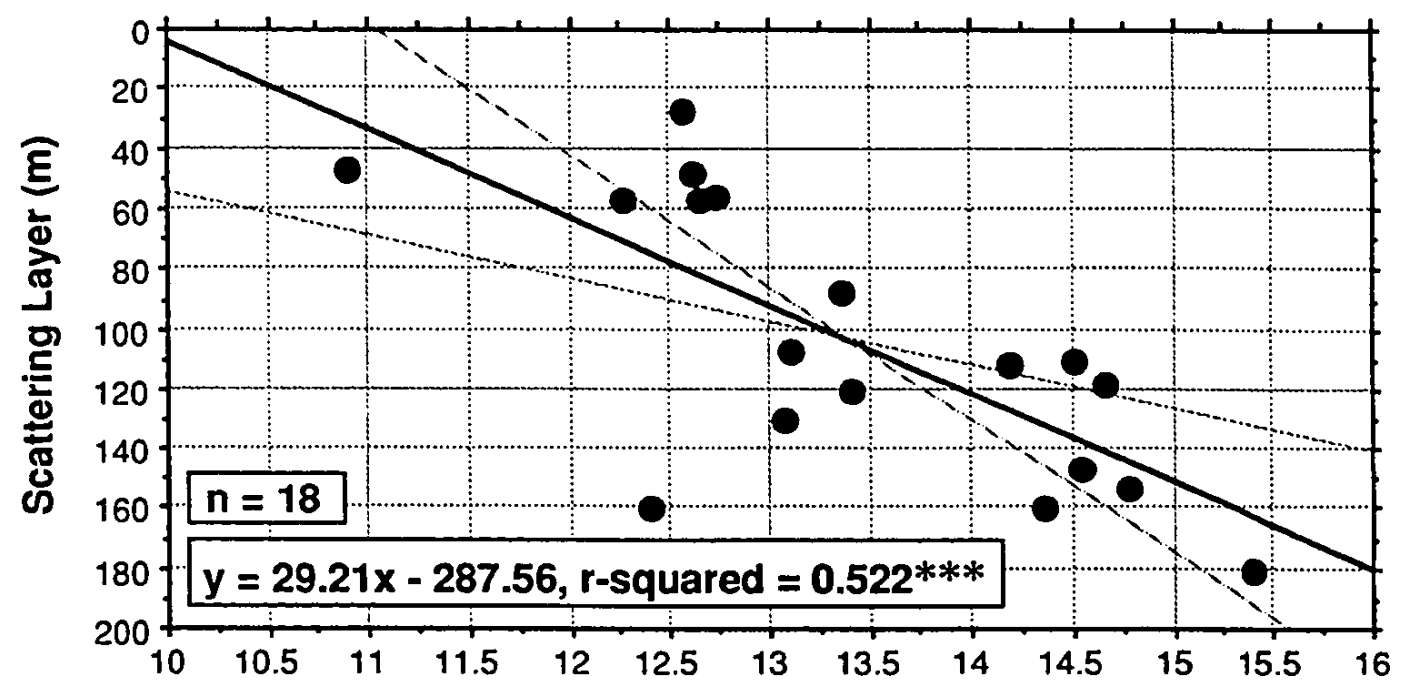

b. 1990

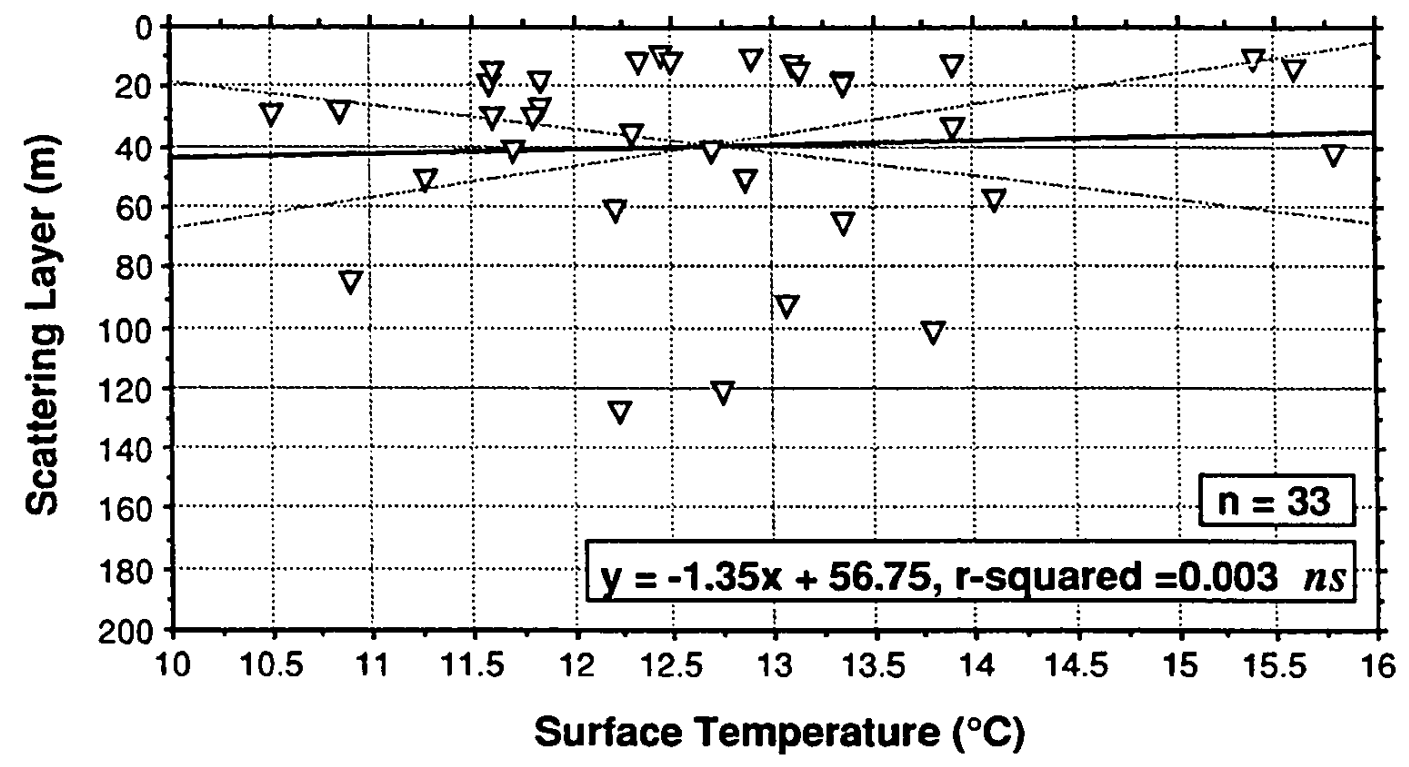

Figure 20. Linear regressions of prey depth versus surface temperature for 1989 and 1990. Equations, $95 \%$ confidence limits for the slope of regression line, and significance levels (*** $\mathrm{P}<0.001$ and $n s=$ not significant) are shown. 
Overall, irradiance (overcast vs sunny) was not significantly related to prey depth in 1989 or 1990 . Mean irradiance was slightly greater in 1989 (1031 $\mu \mathrm{E} \mathrm{m}^{-2} \mathrm{~s}^{-1} \pm 439.3 \mathrm{SD}, \mathrm{n}=40$ ) than 1990 (988 $\left.\mu \mathrm{E} \mathrm{m}^{-2} \mathrm{~s}^{-1} \pm 448.1 \mathrm{SD}, \mathrm{n}=158\right)$. However, during September, irradiance in 1989 was significantly greater than $1990\left(1567 \mu \mathrm{E} \mathrm{m}^{-2} \mathrm{~s}^{-1} \pm 154.6 \mathrm{SD}\right.$ vs. $1243 \mu \mathrm{E} \mathrm{m}^{-2} \mathrm{~s}^{-1} \pm 469.9 ; \mathrm{Z}=2.35, \mathrm{df}=\infty$, $P<0.05)$. Light avoidance by euphausiid prey was not apparent in 1989 or 1990 , but their orientation to daily fluctuations in light levels (phototaxis) was positive. In 1990, there was a the slight vertical movement of the scattering layer (approx. $20 \mathrm{~m}$ ) to increasing and decreasing light levels during the study period (Fig. 21).

In 1989, prey depth was positively correlated $(r=0.96, P<0.05)$ with the monthly magnitude of red tide as determined by the Department of Health (Fig. 22). Red tide blooms varied in duration and extent during the three-year study period (Fig. 23). In late October 1988, a red tide bloom was observed around Bodega Bay. The red tide blooms in early October and late November 1990 were comparable, extending $16 \mathrm{~km}$ off Bodega Bay. The 1989 bloom persisted much longer, from September to mid-October, and its range extended much further out, approximately $32 \mathrm{~km}$ out from Bodega Bay to the Farallon Islands and Cordell Bank (Fig. 23).

Dinoflagellate species varied among years and locations. Red tide samples collected in the study area were composed of Noctiluca scintillans in all three years and were red/orange. In 1988 and 1990, brief outbreaks of brownish/red Ceratium tripos (red was Noctiluca scintillans intermixed) occurred in late October 1988, and were present in early October and late November in 1990. 


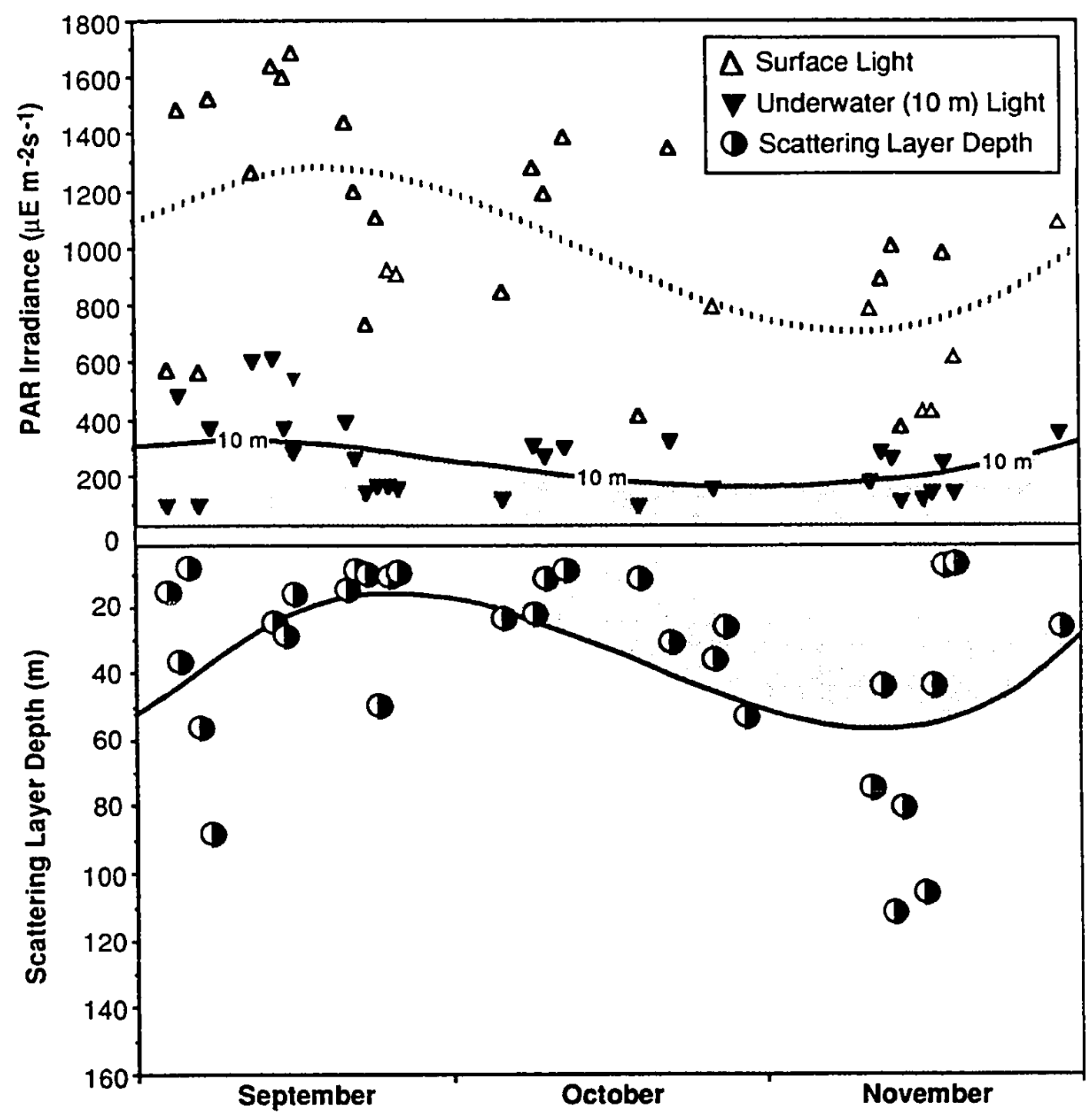

Figure 21. Fitted curves comparing mean daily surface light and underwater $(10 \mathrm{~m})$ light with scattering layer depths for the months of September, October, and November in 1990. Total light energy was restricted to the wavelengths between 300 and $720 \mathrm{~nm}$ or photosynthetically available radiation (PAR). 


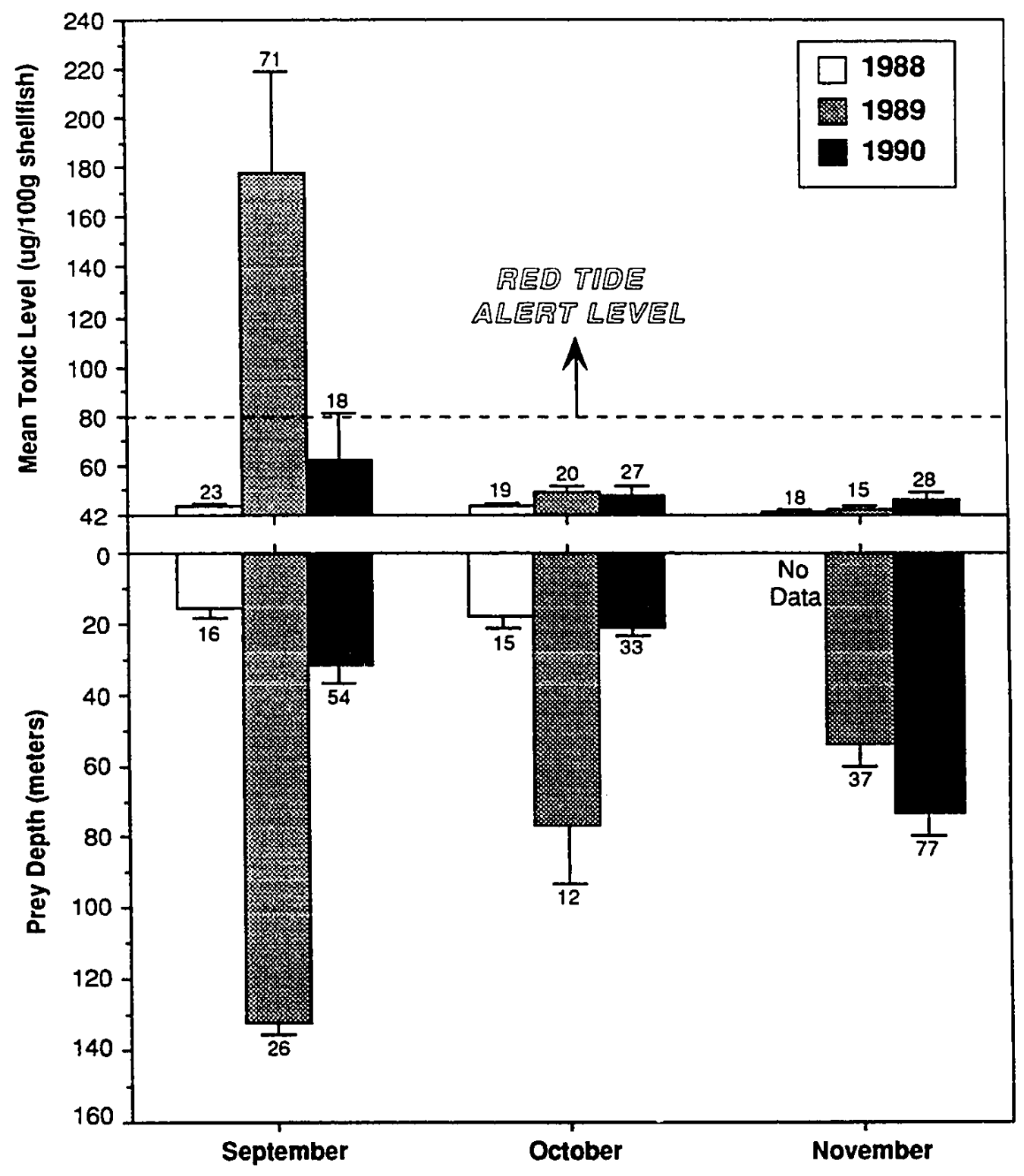

Figure 22. Monthly mean Paralytic Shellfish Poison (PSP) toxin levels for Marin County, California, and mean prey depth for the months of September, October, and November in 1988-90. Micrograms of toxin per 100 grams of intertidal mussel and oyster shellfish were analyzed. Levels below 42 are below the limits of detection, and levels of 80 or above are alert levels (PSP data are from the Department of Health Services, CA, PSP Final Reports). Monthly sample sizes (above and below bars) and standard errors (length of t-bars) are shown. 


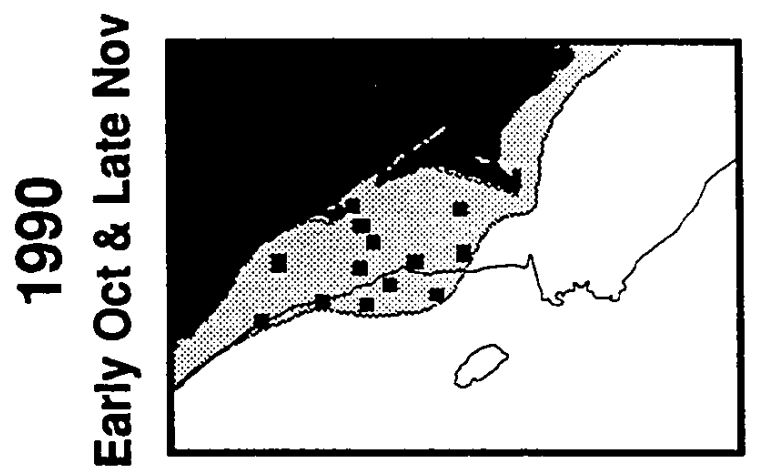

뭉 웡

g్

동

윻

ह ㅎํㄴ

\%

合苋

我 $\frac{\Phi}{1}$

o $\$$ 흥

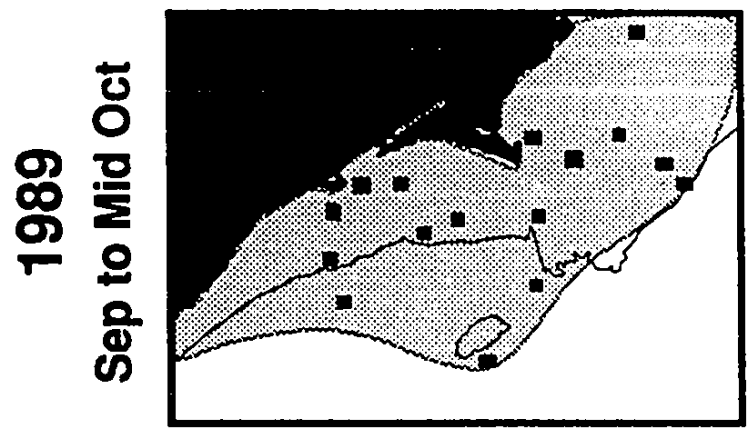

这

응 क

잉 응

甲 웅

뜬

.

Ф 8

을은

郘要

다응

옹

용 옹

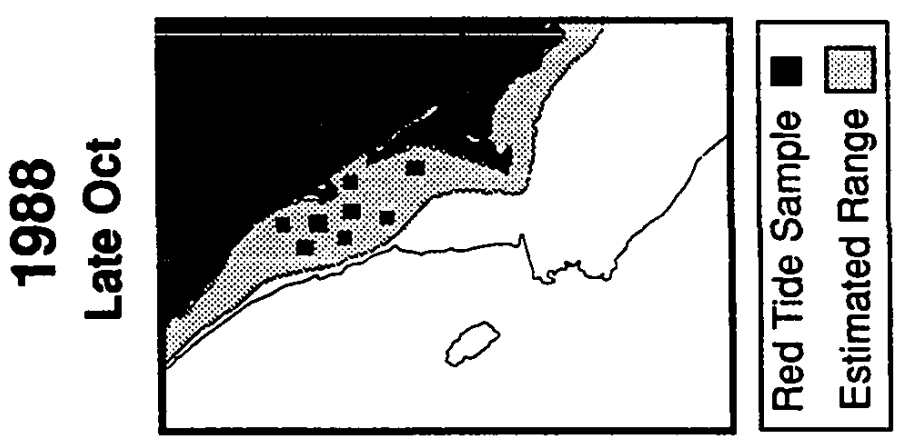

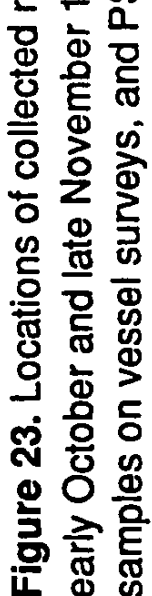


In contrast, samples collected early during the extensive 1989 bloom contained the toxic dinoflagellate, Alexandrium catenella (previously named Gonyaulax catenella) and was succeeded in late September by a thick bloom of Noctiluca scintillans. 


\section{DISCUSSION}

\section{Foraging Behavior and Energetics}

Humpback whale feeding behavior differed significantly in 1989 compared with 1988 and 1990, corresponding closely to differences in prey depth. Surface feeding was typically lateral lunging preceded by a fine-misted bubble-cloud emitted underwater and observed at the surface. Though it is not known how whales create this cloud, it is possible that they emit bubbles from their mouth, allowing their baleen to sieve a mist of fine bubbles which rise to the surface (Reidenberg and Laitman 1991; J. Reidenberg, pers. comm., 1991; Fig 10). In an aquarium, bubbles emitted from an air stone disoriented $T$. spinifera. Fine bubbles adhered to their feeding appendages and under their carapaces; this disrupted free swimming and immediately drove them to the surface (Komaki 1966; Kieckhefer pers. obs. 1990). Bubble-clouds produced by feeding whales may similarly incapacitate swimming euphausiids and concentrate them at the water's surface (Jurasz and Jurasz 1979; Hain et al. 1882; Baker 1985), making surface feeding more efficient. Other feeding behaviors using bubbles, like bubble-net feeding (Ingebrigsten 1929; Jurasz and Jurasz 1979; Hain et al. 1982), were not observed. Likewise, Dohl et al. (1983) from 1980 to 82 and Calambokidis et al. (1989a, 1991a) from 1986 to 1990 never observed humpback whales bubble-net feeding in the study area. There were a few unconfirmed reports of bubble-net feeding further south, off Pigeon Point and Half Moon Bay, possibly correlated with humpback whales feeding on northern anchovy (R. LaMar, pers. comm. 1990).

Surface-feeding groups were observed on four occasions in 1988 and 
on eleven occasions in 1990, where two or three whales appeared to combine their efforts in capturing prey. On eight occasions, pairs of whales were repeatedly observed lateral lunging in tandem (approximately $4 \mathrm{~m}$ between individuals), whereas on four occasions, one whale would execute a lateral lunge immediately followed by a second following whale executing a diagonal lunge. On three occasions, whale trios were observed apparently feeding cooperatively. The two outside whales lateral lunged, while the center whale performed either a vertical or diagonal lunge. This feeding method, known as "echelon" feeding, was used by humpback whales feeding in southeast Alaska (Baker 1985) and by skim feeding bowhead whales in the Arctic (Würsig et al. 1984; Würsig 1988). It is possible that this configuration of whale feeding counteracts the classic escape response of schooling prey (e.g. fountaining or swimming around and behind the stimulus), because the trailing whale intercepts prey escaping from the lead whale (Pitcher and Wyche 1983; Hamner et al. 1983; Hamner 1984; Baker 1985; Hall et al. 1986; O'Brien 1987; Strand and Hamner 1990).

Nevertheless, cooperative surface feeding was rarely seen, compared with southeast Alaska. In southeast Alaska, larger groups (8-11) have been observed feeding on faster, more mobile prey, such as Pacific herring (Jurasz and Jurasz 1979; Baker 1985; D'Vincent et al. 1985). It is possible that feeding on euphausiids does not require a cooperative effort, because euphausiids are slower swimmers than fish.

Humpback whales feeding cooperatively on schooling fish vocalize before surface lunging in southeast Alaska (D'Vincent et al. 1985). In addition, it has been reported that humpback whales feeding in the same area, on 
euphausiids and fish vocalize when they create bubble-nets (Payne 1979; Kieckhefer pers. obs. 1982). It has been suggested that the mechanical vibration created by humpback whale vocalizations may assist in corralling prey or coordinating group efforts (Baker 1985; D'Vincent et al. 1985). In contrast, humpback whales feeding near Cordell Bank were silent ( $n=18$, Table 2).

Songs of humpback whales were recorded several times in the Cordell Bank area. Though songs are generally produced in the breeding grounds (e.g. Schevill 1964; Winn and Winn 1978; Thompson et al. 1979), humpback songs have been reported in the feeding areas in the North Atlantic (Stellwagen Bank, Massachusetts; Mattila et al 1987) and North Pacific (Stephens Passage/Frederick Sound, Alaska; McSweeney et al. 1989). Mattila et al. (1987) suggested that singing in the feeding grounds may be related to (1) mixing of individuals from different regions or to (2) unknown factors that stimulate migration. Because humpback whales are often sighted in the study area from April through December with peak abundance in September (Dohl et al. 1983, Calambokidis et al. 1989a) and when songs were first recorded in this study (Table 2), it is more likely that the former theory, relating to mixing, would be true. In general, vocalizations of any nature produced in the feeding grounds could confer some feeding advantage. For example, they may inform other whales of a localized food source (Mobley et al. 1988).

Surface feeding was characterized by fast, short-duration dives, and rapid surface swim speeds compared with deep diving, thus possibly incurring higher oxygen demand (Costa 1991). In 1989 and 1990, blow rates of surface feeding whales were significantly greater than deep feeding whales in 1988 and 1990. It is likely that euphausiids at the surface avoided predators better in 
deep than shallow water. Well illuminated, relatively warm surface water may enable them to detect shadows more easily, cooperate in more efficient evasive schooling responses, and move faster (O'Brien 1987; Strand and Hamner 1990). Cooperative surface feeding among humpback whales in this setting may greatly increase feeding success.

Costa (1991) asserted that the major factors influencing whether a predator will pursue prey at a specific depth are prey type, size and energy content, and behavior. At deeper depths, whales have no barriers, comparable to the air-water interface, against which to trap prey. Deeper prey depths require longer more demanding travel times. In 1989, whales made long-duration dives up to $17 \mathrm{~min}$, and had extended durations of up to $9 \mathrm{~min}$ at the surface. At the surface, whales appeared to be hyperventilating, swimming slowly (0-1 kts) and breathing up to 23 times. In 1989, feeding humpback whales appeared extremely lethargic at the surface compared to the rapid, high-energy swimming of surface feeding whales in 1988 and 1990. Hamner et al. (1988) reported southern right whales (B. australis) slowly moving at the surface and hyperventilating before long dives to feed on sub-surface Antarctic krill (Euphausia superba). Because only deep-dwelling prey were available in 1989 , whales apparently reduced their oxygen consumption by slowing down their swimming speed at the surface.

Time spent at the surface has been correlated positively with the duration of preceding dive of Weddell seals (Leptonychotes weddelli; Kooyman et al. 1980), bottlenose dolphin (Tursiops truncatus, Ridgway 1986, Ridgway et al. 1969), gray whales (Eschrichtius robustus, Harvey and Mate 1984; Würsig 1984; Würsig et al. 1986), southern right whales (Eubalaena australis, Hamner 
et al 1988), sperm whales (Physeter macrocephalus, Lockyer 1977), and humpback whales (Baker 1985; Bauer 1986; Dolphin 1987a,b,c,d). The dive depth of humpback whales during feeding can be predicted with a high degree of confidence from their respirations and dive patterns (Dolphin 1987b).

Transit time to prey during deep dives was shortened by increasing the angle of descent. Humpback whales raise their posterior and flukes high into the air by braking forward momentum with their pectoral fins rotated forward, thus providing the initial downward thrust needed for sub-surface dives (Edel and Winn 1978; Kieckhefer pers. obs. 1983; Fig. 12). The angle of the body during a dive $\left(30^{\circ}, 45^{\circ}\right.$, or $\left.90^{\circ}\right)$ was dependent on their swim speed and angle of their pectoral fins. In this study, fluke-up and high fluke-up dives were seen mostly during shallow and deep feeding. On seven occasions, depth sounder traces indicated humpback whales diving to deep scattering layers at an angle $>70^{\circ}$ after high fluke-up dives. In addition, whales were consistently observed flexing their tail stock before deep dives $(77 \%)$. This behavior may enhance body circulation from consecutive deep diving periods, or generate enough momentum to reach a steep angle to descend more quickly to desired depths. These whales may have been diving as deep as 180 meters, based on depth of scattering layer (Fig. 19a). More direct evidence, such as time-depth records, are needed to confirm the actual feeding depth of humpback whales.

The maximum feeding depth of humpback whales is unknown; however, it is assumed that baleen whales do not exceed $\mathbf{3 0 0}$ meters in depth (Nemoto 1963). In the North Atlantic, Whitehead (1983) obtained depth sounder traces of humpback whales traveling to depths of $195 \mathrm{~m}(n=104)$, whereas in southeast Alaska, Dolphin (1987a) found that humpback whales restricted their feeding to 
the upper $120 \mathrm{~m}(n=284)$ and only 8 dives $(3 \%)$ exceeded $120 \mathrm{~m}$. Dolphin (1987a) suggested that extended surface intervals and steady ventilations may be indications that these whales are exceeding their aerobic dive limit, revitalizing their oxygen debt after continuous deep dives. This suggestion was based primarily on anaerobic diving debts in seals, in which disproportionate increases in surface duration results (Kooyman et al. 1980). However, the slower swimming speed of humpback whales during deep, long duration dives may use oxygen more slowly, thus avoiding anaerobic diving (Kooyman 1989; Costa 1991).

\section{Prey Distribution and Relative Abundance}

Euphausiids represent a major fraction (5-10\%) of the total biomass of plankton, and are a major food source for many marine birds, seals, and baleen whales (Mauchline 1980). However, it is not their numbers alone that make them so important in the food chain, but that they live in great concentrations. Thysanoessa spinifera are dominant in the neritic (coastal) environment, and E. pacifica is found further offshore along the northeast Pacific coast (Brinton 1962a; Hebard 1966; Youngbluth 1976). Extensive surface shoals of $T$. spinifera form along the California coast from Fort Ross to the Channel Islands (Barham 1956; Brinton 1962a; Harvey 1979; Smith and Adams 1988; Schoenherr 1991). Hebarb (1966) found that $T$. spinifera was the most abundant species of euphausiid off Oregon from September through February. In the coastal areas of the Bering Sea, humpback whales fed largely on $T$. spinifera and its egg masses (Hollis 1939). During this study, humpback whale fecal samples and plankton tows confirmed that $T$. spinifera was the primary 
euphausiid prey.

Plankton tows obtained during this study support Brinton's findings (1962b) that $T$. spinifera remains in the upper $100 \mathrm{~m}$, whereas $E$. pacifica performs diurnal vertical migrations, with peak abundance at 200-400 m during daylight and at the surface at night. Thysanoessa spinifera was found predominantly in surface and shallow tows, whereas $E$. pacifica was $99.6 \%$ of the biomass in deep tows. The occurrence of $E$. pacifica in humpback whale fecal samples in 1989 may have been associated with whales feeding deep and further offshore along the continental shelf break.

Rice (1978) reported that stomach contents of humpback whales killed from 1956 to 1965, in the vicinity of Cordell Bank/Farallon Islands, contained roughly $60 \%$ northern anchovy and $40 \%$ Euphausia pacifica, with only trace amounts $(<0.5 \%)$ of Pacific herring and Thysanoessa spinifera. Catcher boats operated $230 \mathrm{~km}$ from the Golden Gate Bridge, off the continental slope/edge in water depths of 2,700 to 4,000 meters (Rice 1963, 1971). Distance offshore may explain the high percentage of $E$. pacifica compared with $T$. spinifera in those humpback whales (Rice 1977; D. W. Rice. pers. comm. 1991). Five sub-samples of humpback whale stomachs from whales taken during the 1956-65 Cordell/Farallon whaling fishery (National Marine Mammal Laboratory, Seattle, WA) were examined. These samples contained mostly E. pacifica $(>98 \%)$, which correlated with whales captured beyond the continental shelf in water depths of 2,200 to 3,700 meters (Table 5). 


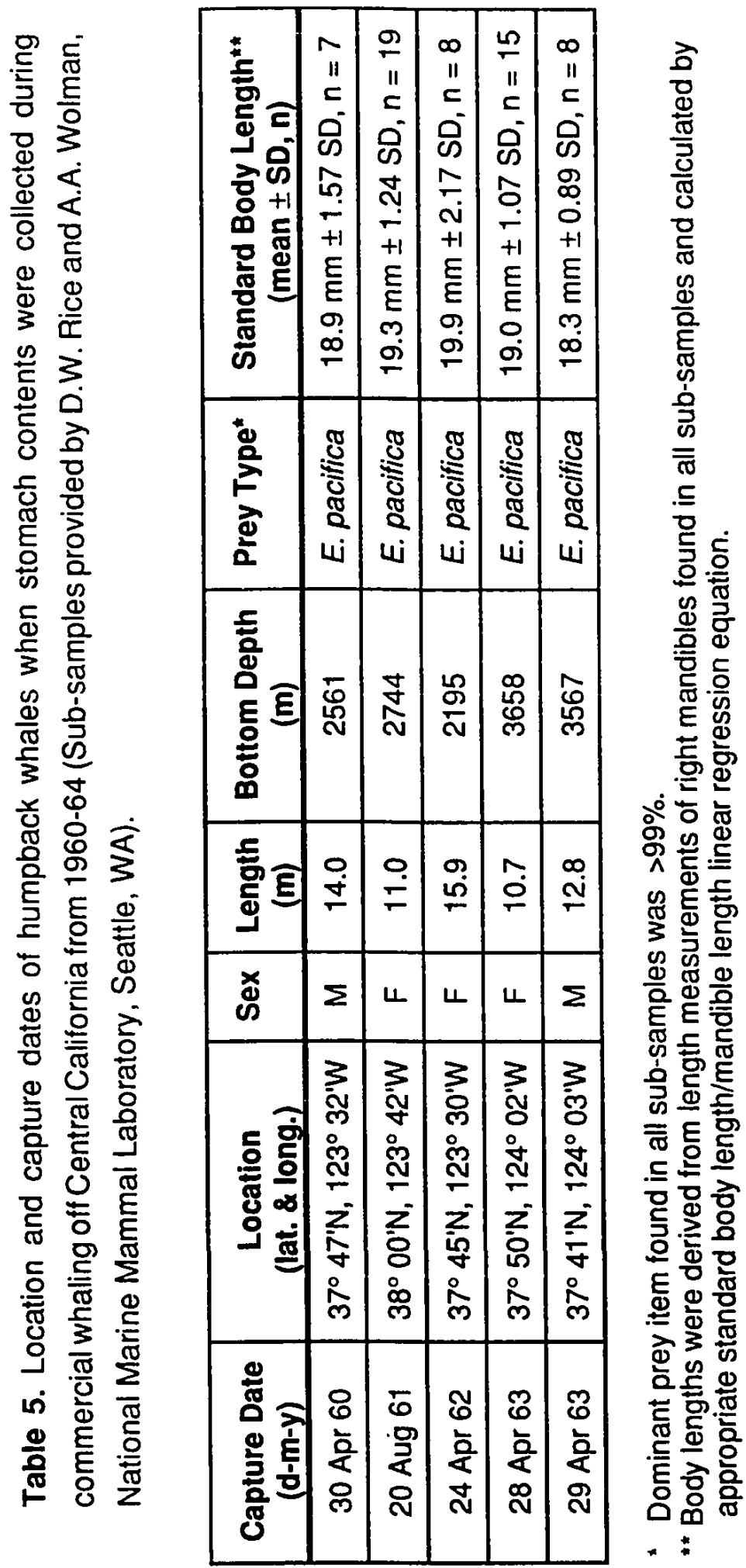


The formation of surface or subsurface swarms has been reported in 18 species of euphausiids living predominantly in higher latitudes (Omori and Hamner 1982). Euphausiids feed mainly on phytoplankton and/or small zooplankton, such as copepods. Daytime surface swarming of euphausiids is of interest, because they differ from normal vertical migrators. The factors that bring about the formation of daytime surface swarms are not clear and may be different for each species. Theories proposed to account for daytime surface swarms are: (1) predators driving euphausiids to the surface (Bigelow and Schroeder 1953; Komaki 1967; Brown et al. 1979; Endo 1984), (2) euphausiids congregating at the surface to feed (Mauchline and Fisher 1969; Brown et al. 1979; Hamner 1984), (3) maturation or reproduction occurring at surface (Endo 1984; Nicol 1984; Smith and Adams 1988), (4) passive transportation to the surface by currents or tides (Brinton 1962b; Forsyth and Jones 1966; Brown et al. 1979; Schoenherr 1991), or (5) a breakdown of an environmental barrier, such as a thermocline, which enables them to vertically migrate to the surface (Komaki 1967; Endo 1984).

Surface swarms of $E$. pacifica are rare along the California coast, whereas surface swarms of $T$. spinifera are common during summer (Brinton 1962b). Because T. spinifera remains in the upper $100 \mathrm{~m}$ both day and night, in contrast to $E$. pacifica's diel vertical migrations, the California current's strong thermocline throughout most of the year may act as a barrier to $E$. pacifica occurrence at the surface. Endo (1984) found E. pacifica at the surface in spring off Sanriku, Japan. He suggested that the absence of a thermocline in early spring allowed $E$. pacifica to swarm at the surface. In the lower St. Lawrence estuary, Canada, Thysanoessa raschi and $M$. norvegica, however, 
had no difficulty crossing the thermocline during their diel vertical migrations (Simard et al. 1986).

Smaller euphausiids caught in plankton tows than found in fecal samples was likely caused by net avoidance, especially by larger and faster swimming euphausiids. It has been suggested that euphausiids detect nets visually by seeing shadows during the daylight and bioluminescence at night (Wiebe et al.1982), or acoustically by vibrational stimuli of the towing cable, harness, or approaching net (Fleminger and Clutter 1965; Hovekamp 1989). Although the fecal sample size was small $(n=11)$ for $1987-1990$, the overall mean lengths of $T$. spinifera and E. pacifica in fecal samples were consistently larger than net samples, providing a more accurate estimate of size classes of euphausiids eaten by humpback whales.

Higher percentages of fertilized T. spinifera were collected in 1988 and 1990 than 1989 . These undoubtedly comprise a richer food source for humpback whales, which may explain greater numbers of whales in 1988 and 1990 (Calambokidis et al. 1989a). The occurrence of fertilized euphausiid females likely reflects favorable oceanographic conditions that created more productive, nutrient-rich upwelled waters (Brinton 1962b).

Under-estimation of fish feeding was possible, because the digestive system of whales may completely dissolve fish otoliths and other calcium hard parts in its acidic solution before they are excreted (Jobling 1987). However, the coloration of all feces collected were red-brick, indicating euphausiid feeding; versus yellow-green, which indicate anchovy or saury feeding (Rice pers. comm. 1991). Yellow-green feces of humpback whales were frequently seen at the surface off Half Moon Bay and adjacent waters, during aerial surveys 
(R. LaMar, pers. comm. 1990). This strongly suggested that humpback whales fed on fish south of the study area.

\section{Oceanographic Conditions \& Productivity}

To understand fluctuations in prey availability in relationship to humpback whale distribution and abundance near Cordell Bank/Farallon Islands, it is essential to know something about the environment they both inhabit. The annual pattern of currents in the study area are divided into three variable, overlapping periods: (1) upwelling, from February through August; (2) oceanic, from September through October; and (3) Davidson, from November through January (reviewed by Sverdrup et al. 1942). This study focused on the peak feeding period of humpback whales, from September through November (Calambokidis et al. 1989a). During this time, the end of an upwelling period, the entire oceanic period, and the beginning of the Davidson Current were observed. In late summer and fall, the northwest winds subside, causing a reduction in the strength of the offshore California Current and reduction in cold, nutrient-rich coastal waters from upwelling. As a result, warm oceanic water and warm, nutrient-deficient waters from the northward-flowing counter-current (Davidson Current) moves coastward.

The interaction between wind stress and the California current appears to generate upwelling of cold, nutrient-rich water to the sea surface (e.g. Bakun and Parrish 1980; Parrish et al. 1981; Abbott and Barksdale 1991; Strub et al. 1991; Washburn et al. 1991). These seasonal surface conditions probably produce the large zooplankton biomass, which occurs in fall off central California (Abbot and Barksdale 1991; Smith et al. 1986). Topographic features, 
like banks, sea mounts, canyons, and a wide range of continental shelf and slope widths, may have a significant influence on water circulation (Schwing et al. 1991). In this study, Bodega Canyon, Cordell Bank, and the Farallon Islands were the primary sites of feeding activity (Fig. 3). During upwelling periods, these topographic features create eddies, gyres, and fronts which may act as "trophic traps" concentrating and/or attracting prey for whales and other predators (Kenney and Winn 1986; Smith et al. 1986; Piatt et al. 1989; Schwing et al. 1991).

On 2 September 1990, a well-developed cyclonic gyre (Fig. 24 f), apparently generated in the south, deflected out of Bodega Canyon and around to the northeast of Cordell Bank (Ericksen 1991). Whale positions, 3 days before and after this image was taken, were consistently found along the north frontal edge of this gyre. However, if offshore flow is continuous or too strong, less motile organisms, such as phytoplankton and some zooplankton, will be dispersed rapidly offshore, creating relatively unproductive waters inshore (see Fig. 24 and 25, July and August 1989). On the other hand, if wind conditions are weak for long periods, it does not provide proper conditions to set-up of these boundaries between different water masses (Ramp et al. 1991). This was evident from September through December in 1989 (Fig. 24 and 25). Mean monthly upwelling indices for all three years indicated that 1989 had the most upwelling during the strong upwelling period of July and August, and upwelling dropped abruptly in the following months in conjunction with an increase in surface temperatures (Fig. 25). It is predicted that these environmental factors were instrumental in setting-up ideal conditions for red tide blooms (Franks et al. 1989). 


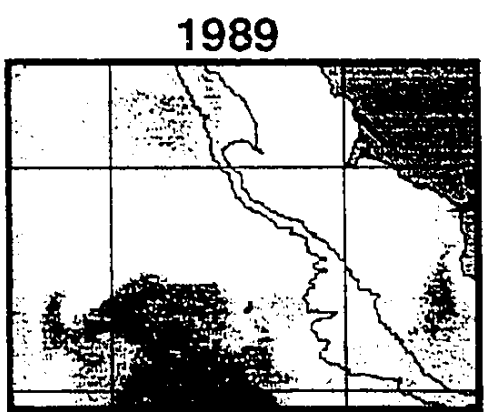

a. July 30

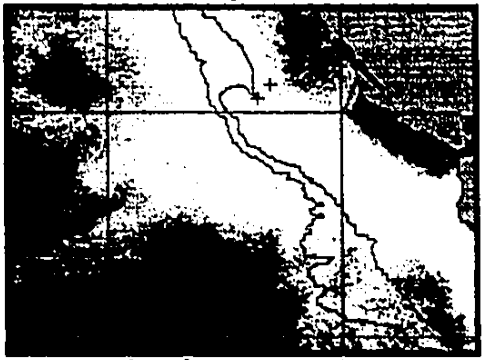

b. August 30

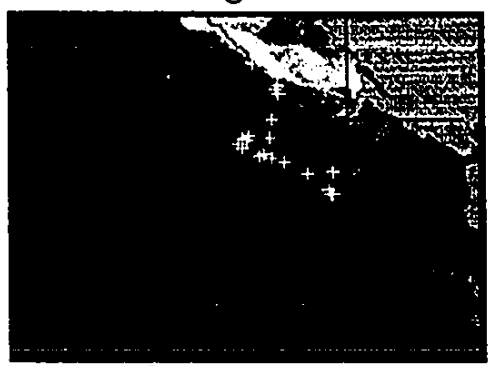

c. September 15

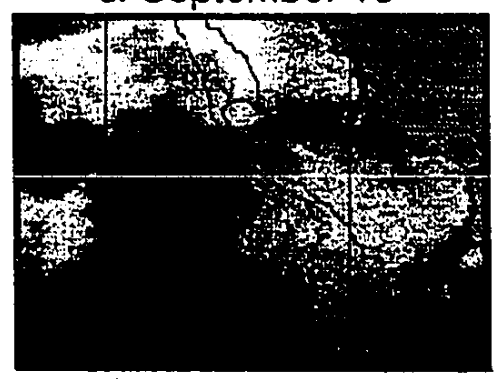

d. November 18
1990

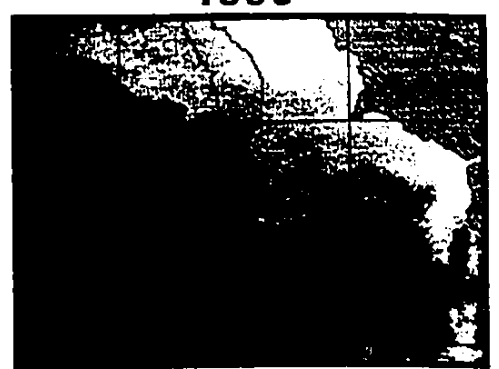

e. August 15

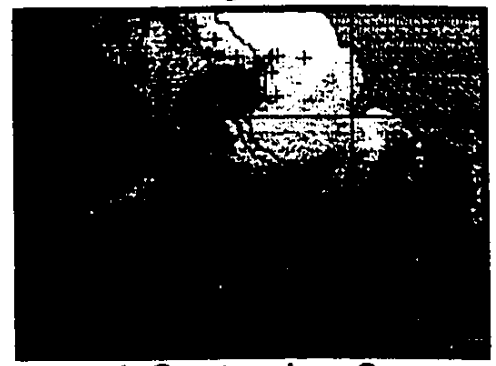

f. September 2

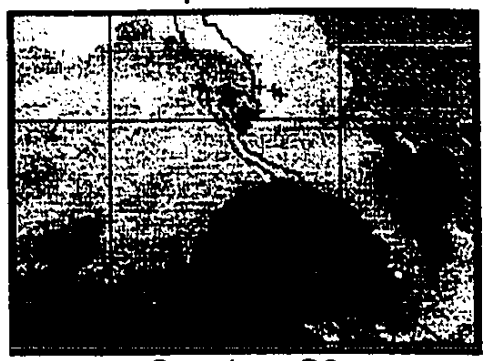

g. October 20

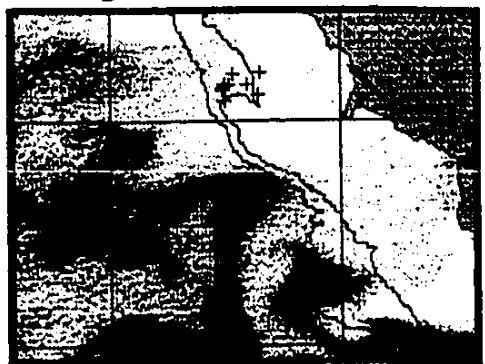

h. November 1

Figure 24. Satellite images (TIROS-N/NOAA) of sea surface temperature (SST) for the most cloud-free days found in 1989 and 1990. For all images the range of linear gray scale was set at $10-16^{\circ} \mathrm{C}$. Lighter shades denote colder water. Plus symbols in $b, c, f, g$, and $h$ denote whale positions 3 days before and after images were taken. The 200 and $1000 \mathrm{~m}$ depth contours are shown. (Images were provided by $\mathrm{N}$. Garfield, Department of Oceanography/Naval Postgraduate School, Monterey, CA). 
a. Coastal Upwelling Indices

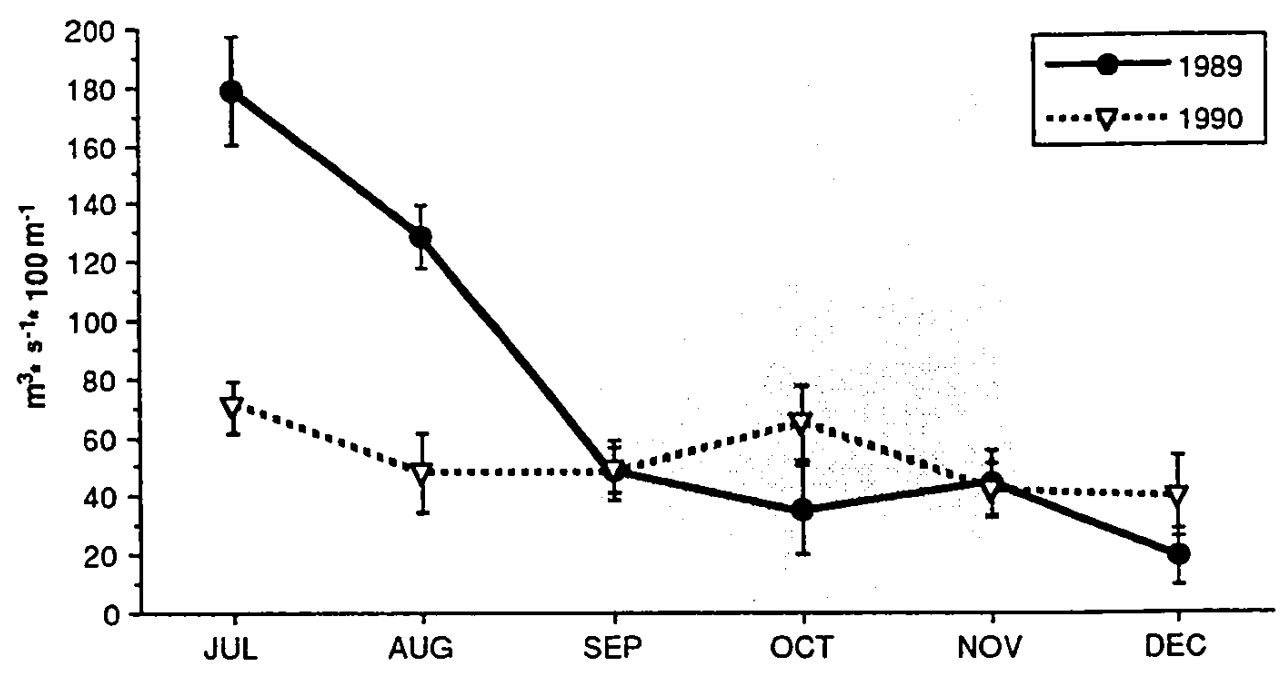

b. Sea Surface Temperature

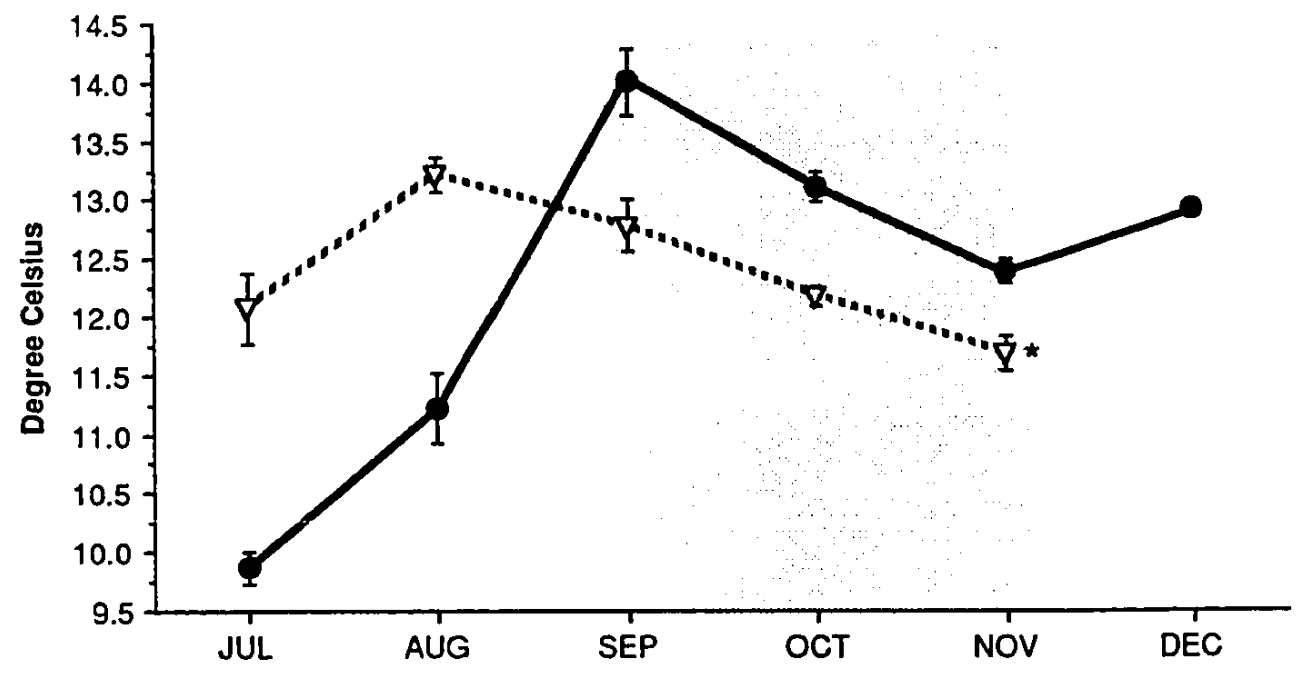

- Note: missing data for entire month of December 1990.

Figure 25. (a) Monthly coastal upwelling indices $\left(m^{3} * s^{-1} * 100 m\right.$ length of coastline $\left.{ }^{-1}\right)$ at $39^{\circ} \mathrm{N}, 125^{\circ} \mathrm{W}$ and $\left(\right.$ b) sea surface temperature $\left(\mathrm{C}^{\circ}\right)$ at NOAA buoy $46013\left(38.2^{\circ} \mathrm{N}, 123.3^{\circ} \mathrm{W}\right)$ for July-December 1989 and 1990 . Note extremely high upwelling and low temperatures during July and August 1989 followed by a sharp decrease in upwelling and increase temperature in September. Study period (shaded area) and standard errors (vertical lines) are shown. (Data provided by D.M. Husby, Pacific Fisheries Environmental Group, Monterey, CA). 


\section{Correlations between Whale Behavior, Prey Occurrence, and Environmental Conditions}

Altered environmental conditions, such as an increase in water temperature by a strong "El Niño," change prey availability for many sea bird populations near the Gulf of the Farallones (e.g. Ainley and Lewis 1974; Ainley et al. 1986; Kaza and Boekelheide 1984; Croll 1990), as well as around the world (review by Cairns 1987). More subtle changes in oceanographic conditions that trigger severe red tide (dinoflagellate) blooms, such as in 1989 , may have physically displaced daytime surface swarming of $T$. spinifera, forcing them deeper in the water column (Boalch 1984, Potts and Edwards 1987, Ogata et al. 1989) or possibly killed them with their fatal toxins (Jenkinson 1989, White et al. 1989). Moreover, humpback whales may die from ingesting prey loaded with dinoflagellate toxins (Anderson 1988; Geraci 1989, Geraci et al. 1989).

Increased light intensity in 1989 may have influenced deeper scattering layers compared with 1988 and 1990. However, direct response of light avoidance by euphausiid prey was not apparent. For example, in 1990, there was a slight vertical migration (approx. $20 \mathrm{~m}$ ) of euphausiid prey to fluctuations of daily light over the study period; however, there was a positive phototaxis response (Fig. 21). In general, dinoflagellate blooms are primarily regulated by various environmental factors such as temperature, sea state (Beaufort), day length, light intensity, and quality and quantity of nutrients (Franks et al. 1989; Imai 1989). The combined environmental conditions in 1989 before the study period (July to August) may have triggered the most intense, wide-spread occurrence of red tide in this area since 1980 (Figs 23, 24, 25). When winds are 
calm and temperatures peak shortly after a strong upwelling period, dormant cysts of dinoflagellates germinate and flourish near the surface waters. The depth of maximum cell concentration appears dependent primarily on light intensity. Passow (1991) hypothesized that dinoflagellates migrated upwards toward higher light intensities until a certain level of irradiance was reached, after which migration was directed downwards to avoid light intensities greater than threshold. Diel vertical migrations of concentrated shoals of dinoflagellates can exceed $40 \mathrm{~m}$ in depth (Passow 1991). During periods of wind, dinoflagellates are mixed deeper, to depths exceeding $40 \mathrm{~m}$, and move near the surface to their threshold light levels during calm periods (Boalch 1984; Passow 1991).

In the Gulf of the Farallones and adjacent waters, seabirds, such as Red phalaropes (Phalaropus fulicaria), Red-necked phalaropes ( $P$. lobatus), and Cassin's auklets (Ptychoramphus aleuticus), feed on surface and shallow subsurface plankton. Phalaropes feed on copepods at the surface of fronts (Brown 1980; Briggs et al. 1984, Haney 1989). Cassin's auklets eat euphausiids primarily near the surface down to depths of $40 \mathrm{~m}$ (Burger and Powell 1990). The percentage decrease of observed Phalaropes (32\% to 0\%) in 1989 may have indicated the disappearance or displacement of copepods deeper in the water column (Fig. 18). Frequency of occurrence of Cassin's auklets also decreased in 1989 ( $42 \%$ to $24 \%$ ), possibly because $T$. spinifera were less abundant (Mauchline 1967; Nemoto 1972). Mean depth of the scattering layer from September through November 1989, was $84.6 \mathrm{~m} \pm 46.30 \mathrm{SD}$, which exceeded the diving capabilities of Cassin's auklets (Burger and Powell 1990). In addition, large variation in Cassin's auklets' diet occurred in 1980 , 
$T$. spinifera was $68 \%$ of diet in 1979 and only $6 \%$ in 1980 , whereas $E$. pacifica increased from $32 \%$ of diet to $75 \%$ (Ainley et al. 1990). This correlates with one of the largest red tide outbreaks in California, which began during the month of July 1980 (Price 1989; Price and Kizer 1990).

Potts and Edwards (1987), working off Plymouth Breakwater, England, observed the physical and toxic effects of the dinoflagellate, Gyrodinium aurelum, on larval, post-larval, and juvenile fish. Juvenile fish were not widely distributed throughout the water column, but were concentrated in a band $50 \mathrm{~cm}$ over the sea floor. Following the bloom there was a dramatic reduction in numbers of larval and post-lanal fish. Boalch (1984) and Jenkinson (1989) reported concentrations of more than five million G. aurelum per liter of water during warm and stable sea conditions, which adversely displaced certain species deeper in the water column. Other less mobile species died, due to viscous, anoxic conditions created in the sea water and/or direct contact with the toxin. Kvitek et al. (1991) suggested that sea otters (Enhydra lutris) in southeast Alaska are displaced horizontally away from red tide blooms to the outer coast where toxic clams are rare.

There appears to be a fine balance between the optimal conditions of humpback whale feeding on surface swarming prey versus adverse conditions when prey are deep in the water column and less aggregated. Information on the demographic structure of the two primary euphausiid stocks, Thysanoessa spinifera and Euphausia pacifica, is needed for the survey area. It is also necessary that whale and prey data be integrated with CTDs, remotely sensed SSTs, and bathymetric data to examine correlations between their distribution and oceanographic features (Fairfield et al. 1991). Underlying hydographic 
processes occurring at this region were most likely missed by remotely sensed SSTs alone. More site-specific knowledge of hydrographic processes existing around the Farallon Islands, Cordell Bank, and Bodega Canyon may provide a better understanding of the physical and biological factors regulating the abundance and distribution of humpback whales and their prey. 


\section{LITERATURE CITED}

Abbot, M.R. and B. Barksdale. 1991. Phytoplankton pigment patterns and wind forcing off central California. J. Geophysical Res. 96(C 8):14,649-14,667.

Ainley, D.G. and T.J. Lewis. 1974. The history of Farallon Island marine bird populations, 1854-1972. Condor, 76(4):432-446.

Ainley, D,G, H.R. Carter, D.W. Anderson, K.T. Briggs, M.C. Coulter, F. Cruz, J.B. Cruz, C.A. Valle, S.I. Fefer, S.A. Hatch, E.A. Schreiber, R.W. Schreiber, and N.G. Smith. 1986. Effects of the 1982-83 El Niño - southern oscillation on Pacific ocean bird populations. Proc. Int. Ornithol. Cong. 19:1747-1758.

Ainley, D.G., Strong, C.G., Penniman, T.M., and R.J. Boekelheide. 1990. Feeding ecology. In Seabirds of the Farallon Islands. Edited by D.G. Ainley and R.J. Boekelheide, Stanford University Press, CA, p.51-127.

Anderson, D. M. 1988. Red tides and toxic algal blooms. WHOI Annual Report, p.16-18.

Baker, C. S. 1984. Population characteristics and feeding behavior of humpback whales in southeast Alaska during 1984. Final report to Auke Bay Laboratory, National Marine Fisheries Service, Auke Bay, AK, 44pp.

Baker, C. S. 1985. Population structure and social organization of humpback whales (Megaptera novaeangliae) in the central and eastern North Pacific. Unpubl. Ph.D. dissertation, Univ. of Hawaii, Honolulu, 306pp.

Baker, C. S., L. M. Herman, B. G. Bays, and G. B. Bauer. 1983. The impact of vessel traffic on the behavior of humpback whales in southeast Alaska: 1982 season. Report to the National Marine Mammal Laboratory, Seattle, WA, 31pp.

Bakun, A. and R.H. Parrish. 1980. Environmental inputs to fishery population models for eastern boundary current regions. In Workshop of the Effects of Environmental Variations on the Survival of Larval Pelagic Fishes Edited by G.D. Sharp, Report no. 28, Intergovern. Ocean. Comm., UNESCO, Paris, p.67-104.

Barham, E.G. 1956. The ecology of sonic scattering layers in the Monterey Bay area, California. Ph.D. Dissertation, Stanford University. 182pp.

Bauer, G. B. 1986. The behavior of humpback whales in Hawaii and modifications of behavior induced by human interventions. Unpubl. Ph.D. Dissertation, University of Hawaii, Honolulu, 306pp. 
Bigelow, H.B. and W.C. Schroeder. 1953. Fishes of the Gulf of Maine. U.S. Fish Wildl. Serv. Bull. 74:1-577.

Boalch, G. T. 1984. Algal blooms and their effects on fishing in the English Channel. Hydrobiologia 116/117:449-452.

Burger, A.E. and D.W. Powell. 1990. Diving depths and diet of Cassin's auklet at Reer Island, British Colombia. Can. J. Zool. 68:1572-1577.

Briggs, K.T., K.F. Dettman, D.B. Lewis, and W.B. Tyler. 1984. Phalarope feeding in relation to autumn upwelling off California. In Marine Birds: their feeding ecology and commercial fisheries relationships. Edited by D.N. Nettleship, G.A. Sanger, and P.F. Springer. Ottawa, Canada:Canadian Wildlife Service, p.51-62.

Brinton, E. 1962a. The distribution of Pacific euphausiids. Bull. Scripps Inst. Oceanogr. Univ. CA 8:51-269.

Brinton, E. 1962b. Variable factors affecting the apparent range and estimated concentration of euphausiids in the North Pacific. Pac. Sci. 16:374-408.

Brown, R.G.B., S.P. Barker and D.E. Gaskin. 1979. Daytime surface swarming my Meganyctiphanes norvegica (M. Sars) (Crustacea, Euphausiacea) off Brier Island, Bay of Fundy. Can. J. Zool. 57:2285-2291.

Brown, R.G.B. 1980. Seabirds as marine animals. In Behavior of Marine Animals, Vol. 4. Edited by J. Burger, B. Olla, and H.E. Winn. Plenum Press, New York, p.1-39.

Cairns, D.K. 1987. Seabirds as indicators of marine food supplies. Biol. Ocean. 5:261-271.

Calambokidis, J., G. H. Steiger, J., J.C. Cubbage, K. C. Balcomb, and P. Bloedel. 1989a. Biology of humpback whales in the Gulf of the Farallones. Final Report to the Gulf of the Farallones National Marine Sanctuary/NOAA, 93pp.

Calambokidis, J., J.C. Cubbage, G. H. Steiger, J. C. Balcomb, and P. Bloedel. 1990. Population estimates of humpback whales in the Gulf of the Farallones, California. Rep. Int. Whale. Comm. (special issue 12):325-333.

Calambokidis, J., G. H. Steiger, J.R. Evenson, T.R. Kieckhefer, K. C. Balcomb, and D.E. Claridge. 1991a. Research on humpback and blue whales in the Gulf of the Farallones and adjacent waters, 1989 and 1990 . Final report to the Gulf of the Farallones National Marine Sanctuary/NOAA and Southwest Fisheries Center, 34pp. 
Calambokidis, J., G. H. Steiger, J.C. Cubbage, K. C. Balcomb, and D.E. Claridge. 1991b. Distribution, abundance, and movements of humpback whales in the Gulf of the Farallones. In Research Within the Gulf of the Farallones: 1991 Workshop. Sponsored by the the Gulf of the Farallones National Marine Sanctuary/NOAA (Abstract).

Costa, D.P. 1991. Reproductive and foraging energetics of high latitude penguins, albatrosses and pinnipeds: implications for life history patterns. Amer. Zool., 31:111-130.

Croll, D.A. 1990. Physical and biological determinants of the abundance, distribution, and diet of the Common Murre in Monterey Bay, California. Studies in Avian Biol., 14:139-148.

Dohl, T. P. 1983. Return of the humpback whale (Megaptera novaeangliae) to central California. In Proceedings 5th Biennial Conference on the Biology of Marine Mammals, Boston, MA (Abstract) p.23.

Dohl, T. P., R.C. Guess, M.L. Duman, and R.C. Helm. 1983. Cetaceans of the central and northern California, 1980-1983: Status, abundance, and distribution. U.S. Dep. Inter. Mineral Manage. Serv. Contract No. 14-120001-29090.

Dolphin, W. F. 1987a. Ventilation and dive patterns of humpback whales, Megaptera novaeangliae, on their Alaska feeding grounds. Can. J. Zool. 65:83-90.

Dolphin, W. F. 1987b. Prey densities and foraging of humpback whales, Megaptera novaeangliae. Experientia, 43(4):468-471.

Dolphin, W. F. 1987c. Dive behavior and estimated energy expenditure of foraging humpback whales in southeast Alaska. Can. J. Zool. 65:354-362.

Dolphin, W. F. 1987d. Foraging dive patterns of humpback whales, Megaptera novaeangliae, in southeast Alaska: a cost-benefit analysis. Can. J. Zool. $66: 2432-2441$.

D'Vincent C. G., R. M. Nilson, and R. E. Hanna 1985. Vocalization and coordinating feeding behavior of the humpback whale in southeast Alaska. Sci. Rep. Whales Res. Inst. 36:41-47.

Edel, R.K. and H.E. Winn. 1978. Observations on the underwater locomotion and flipper movement of the humpback whale Megaptera novaeangliae. Mar. Biol. 48:279-287. 
Endo, Y. 1984. Daytime surface swarming of Euphausia pacifica (Crustacea: Euphausiacea) in the Sanriku coastal waters off northeastern Japan. Mar. Biol. 79:269-276.

Ericksen, C.C. 1991. Observations of amplified flows atop a large seamount. J. Geophysical Res. 96(C 8):15,227-15,236.

Fairfield, C.P., G.T. Waring, M.H. Sano, and J.R. Nicolas. 1991. Cetaceans on the edge. In Proceedings 9th Biennial Conference on the Biology of Marine Mammals, Chicago, IL (Abstract) p.21.

Federal Register 1979. Humpback whale harassment in the Hawaiian Island area. $44(3): 1113-1114$.

Fleminger, A. and R.I. Clutter. 1965. Avoidance of towed nets by zooplankton. Limnol. Oceanogr. 10:96-104.

Forsyth, D.C.T. and L.T. Jones. 1966. Swarming of Thysanoessa longicaudata (Kroyer) (Crustacea, Euphausiacea) in the Shetland Islands. Nature 212:1467-1468.

Franks, P.J.S., D.M. Anderson, and B.A. Keafer. 1989. Fronts, upwelling and coastal circulation: spatial heterogeneity of Ceratium in the Gulf of Maine. In Red Tides: Biology, Environmental Science, and Toxicology Edited by Okaichi, Anderson, and Nemoto. Elsevier Science Publ. Co., Inc., p.153156.

Geraci, J.R. 1989. Sea mammals encounter fatal toxins. In Proceedings 8th Biennial Conference on the Biology of Marine Mammals, Pacific Grove, CA (Abstract) p.23.

Geraci, J.R., D.M. Anderson, R.J. Timperi, D.J. St. Aubin, G.A. Early, J.H. Prescott, and C.A. Mayo. 1989. Humpback whales (Megaptera novaeangliae) fatally poisoned by dinoflagellate toxin. Can J. Fish. Aquat. Sci. 46:1895-1898.

Guerrero, J. A. 1989. Foraging behavior of gray whales in relation to patch dynamics of their benthic prey along Vancouver Island, British Colombia. Unpubl. M.S. thesis, Moss Landing Marine Laboratories/San Jose State University, CA, 43pp.

Hain, J.H.W., G.R. Carter, S.D. Kraus, C.A. Mayo, and H.E. Winn. 1982. Feeding behavior of the humpback whale, Megaptera novaeangliae, in the western North Atlantic. Fish. Bull. 80(2):259-268.

Hall, S.J., C.S. Wardle, and D.N. MacLennan. 1986. Predator evasion in a fish school: test of a model for the fountain effect. Mar. Biol. 91:143-148. 
Hamner, W.M. 1984. Aspect of schooling in Euphausia superba. J. Crust. Biol. 4(Spec. No. 1):67-74.

Hamner, W.M.; P.P. Hamner; S.W. Strand and R.W. Gilmer. 1983. Behavior of Antarctic krill, Euphausia superba: chemoreception, feeding, schooling, and molting. Science 220:433-435.

Hamner, W.M., G.S. Stone, and B.S. Obst. 1988. Behavior of southern right whales, Eubalaena australis, feeding on the Antarctic krill, Euphausia superba. Fish Bull. 86(1):143-150.

Haney, J.C. 1989. Iterative techniques for characterizing marine bird habitats with time-series of satellite images. Colonial Waterbirds 12(1):78-89.

Harvey, J.T. 1979. Aspects of the life history of the blue shark, Prionace glauca L., in Monterey Bay, California. Unpubl. M.S. thesis, Moss Landing Marine Laboratories/San Jose State University,CA, 86pp.

Harvey, J.T., and B.R. Mate. 1984. Dive characteristics and movements of radiotagged gray whales in San Ignacio Lagoon, Baja California Sur, Mexico. In The Gray Whale Edited by M.L. Jones, J.S. Leatherwood, and S. Swartz. Academic Press, New York, p.561-575.

Hebarb, J.F. 1966. Distribution of Euphausiacea and Copepoda off Oregon in relation to oceanographic conditions. Unpubl. Ph.D. dissertation, Oregon State Univ., Corvallis, 84pp.

Hobson, E.S. and D.F. Howard. 1989. Mass strandings of juvenile shortbelly rockfish and Pacific hake along the coast of northern California. Calif. Fish and Game. 75(3):169-183.

Hoeskstra, J.A. and J.J. Jansen. 1986. Statistical significance in comparative ethological experiments. Appl. Animal Beh. Sci. 16:303-308.

Hollis, E.H. 1939. Biological report of the United States Bureau of Fisheries. Food and parasites of whales collected during the season 1937-1938. Norsk Hvalfangst-Tid. 1:13-17.

Hovekamp, S. 1989. Avoidance of nets by Euphausia pacifica in Dubob Bay. J. Plankton Res. 11(5):907-924.

Imai, I. 1989. Cyst formation of the noxious red tide flagellate Chattonella marina (Raphidophyceae) in culture. Mar. Biol. 103:235-239.

Ingebrigsten, A. 1929. Whales caught in the North Atlantic and other seas. Int. Counc. Explor. Sea, Rapp. P.V. Reun. 56:1-26. 
Jenkinson, I. R. 1989. Increases in viscosity may kill iish in some blooms. In Red Tides: Biology, Environmental Science, and Toxicology. Edited by T.

Okaichi, D.M. Anderson, T. Nemoto. Elsevier Publishing Corp., p.435-438.

Jobling, M. 1987. Marine mammal faeces samples as indicators of prey importance - A source of error in bioenergetics studies. Sarsia 72:255-260.

Jurasz, C. M. and V. P. Jurasz. 1979. Feeding modes of the humpback whale, Megaptera novaeangliae, in southeast Alaska. Sci. Rep. Whales Res. Inst. 31:69-83.

Kathman, R.D., W.C. Austin, J.C. Saltman, and J.D. Fulton. 1986. Identification Manual to the Mysidacea and Euphausiacea of the Northeast Pacific. Dept. Fish and Oceans, Ottawa, Canada, 411pp.

Katona, S., S. Baxter, O. Brazier, S. Kraus, J. Perkins, and H. Whitehead. 1979. Identification of humpback whales by fluke photographs. In Behavior of marine animals, current perspectives in research. Vol. 3. Cetaceans. Edited by H. E. Winn and B. L. Olla. Plenum Publishing Corp., p.33-44.

Kaza, S. and R. Boekelheide. 1984. Measuring the pulse of life. Pac. Discovery Jan-Mar issue, p.7-13.

Kenney, D.R. and H.E. Winn 1986. Cetaceans high-use habitats of northeast United States continental shelf. Fish. Bull. 84(2):345-357.

Komaki, Y. 1966. Technical notes on keeping euphausiids live in the laboratory, with a review of experimental studies on euphausiids. Info. Bull. Plank. Jap., 13:95-105.

Komaki, Y. 1967. On the surface swarming of euphausiid crustaceans. Pac. Sci. $21: 433-448$.

Kooyman, G.C.(ed) 1989. Diverse Divers: physiology and behavior. Berlin: Springer-Verlag, 200pp.

Kooyman, G.L., E.A. Wahrenbrock, M.A. Castellini, R.W. Davis, and E.E. Sinnett. 1980. Aerobic and anaerobic metabolism during voluntary diving in Weddell seals: evidence of preferred pathways from blood chemistry and behavior. J. Comp. Physiol. 138:335-346.

Krieger, K.J. 1988. Relationship between prey abundance and usage of Glacier Bay by humpback whales. In Proceedings of the 2nd Glacier Bay Science Symposium, Glacier Bay Lodge, AL, p.90-95. 
Krieger, K. and B.L. Wing. 1984. Humpback whale prey studies in southeast Alaska, Summer 1983. Report to the Northwest and Alaska Fisheries Center, Auke Bay Laboratory, Auke Bay, AK, 42pp.

Kvitek, R.G., A.R. DeGange, and M.K. Beitler. 1991. Paralytic shellfish poisoning toxins mediate feeding behavior of sea otters Limnol. Oceanogr., 36(2):393-404.

Larson, R.J. (ed). 1987. Progress in rockfish recruitment studies at the Tiburon Laboratory. Southwest Fisheries Center. Administrative report T-87-01, $31 \mathrm{pp}$.

Lockyer, C. 1977. Observations on diving behavior of the sperm whale. In A Voyage of Discovery. Edited by M. Angel. Pergamon press Ltd., Oxford, p.591-609.

Mathews, L.H. 1937. The humpback whale, Megaptera nodosa. Disc. Repts. 17:7-92.

Mattila, D.K., L.N. Guinee, and C.A. Mayo. 1987. Humpback whale songs on a north Atlantic feeding ground. J. Mamm., 68(4):880-883.

Mauchline, J. 1967. Feeding appendages of the Euphausiacea (Crustacea). J. Zool., Lond. 153:1-43.

Mauchline, J. 1980. The biology of mysids and euphausiids Adv. Mar. Biol. 18:1-680.

Mauchline, J. and L.R. Fisher. 1969. The biology of euphausiids Adv. Mar. Biol. 7:1-454.

McSweeney, D.J., K.C. Chu, W.F. Dolphin, and L.N. Guinee. 1989. North Pacific humpback whale songs: a comparison of southeast Alaskan feeding ground songs with Hawaiian wintering ground songs. Mar. Mammal Sci. 5:139-148.

Mobley Jr., J.R., Herman, L.M., and A.s. Frankel. 1988. Responses of wintering humpback whales, Megaptera novaeangliae, to playback recordings of winter and summer vocalizations and synthetic sounds. Behav. Ecol. and Sociobio., 23:211-223.

Nemoto, T. 1963. Some aspects of the distribution of Calanus cristatus and $C$. plumchrus in the Bering Sea and its neighboring waters, with reference to the feeding of baleen whales. Sci. Rep. Whal. Res. Inst. Tokyo, (14):149290. 
Nemoto, T. 1970. The feeding pattern of baleen whales in the ocean. In Marine Food Chain. Edited by J.H. Steele. Oliver and Boyd, Edinburgh, p.241-381.

Nemoto, T. 1972. History of research into the food and feeding of euphausiids. Proc. R.S.E. (B) 73:259-264.

Nicol, S. 1984. Population structure of daytime surface swarms of the euphausiid Meganyctiphanes norvegica in the Bay of Fundy. Mar. Ecol. Prog. Ser. 18:241-251.

O'Brien, D.P. 1987. Description of escape responses of krill (Crustacea: Euphausiacea), with particular reference to swarming behavior and the size and proximity of the predator. J. Crust. Biol. 7(3):449-457.

Ogata, T., M. Kodama, and T. Ishimaru. 1989. Effect of water temperature and light intensity on growth rate and toxin production of toxic dinoflagellates. In Red Tides: Biology, Environmental Science, and Toxicology. Edited by T. Okaichi, D.M. Anderson, T. Nemoto. Elsevier Publishing Corp., p.423426.

Omori, M. and W.M. Hamner. 1982. Patchy distribution of zooplankton: behavior, population assessment and sampling problems. Mar. Biol. 72:193-200.

Parrish, R.H., C.S. Nelson, and A. Bakun. 1981. Transport mechanisms and reproductive success of fishes in the California Current. Biol. Ocean. $1(2): 175-203$.

Parsons, T.R., M. Takahashi, B. Hargrave (editors). 1984. The primary formation of particulate materials. In Biological Oceanographic Processes (3rd Edition). Pergamon Press, p.61-118.

Passow, U. 1991. Vertical migration of Gonyaulax catenata and Mesodinium rubrum. Mar. Biol. 110:455-463.

Payne, R.S. 1979. Humpbacks: their mysterious songs. Nat. Geog. 155:18-25.

Payne, R.S. and S. McVay. 1971. Songs of humpback whales. Science, 173:587-597.

Piatt, J.F., D.A. Methven, A.E. Burger, R.L. McLagan, V. Mercer, and E. Creelman. 1989. Baleen whales and their prey in a coastal environment. Can. J. Zool. 67:1523-1530.

Pitcher, T.J. and C.J. Wyche. 1983. Predator-avoidance behaviors of sand-eel schools: why schools seldom split. In Predators and Prey Fishes. Edited by L.G. Noakes et al. Dr. W. Junk Publishers, Netherlands. p.193-204. 
Potts, G.W. and J.M. Edwards. 1987. The impact of a Gyrodinium aureolum bloom on the inshore young fish populations. Evol. Biol. Ass., U.K, 67:293297.

Preisendorfer, R.W. 1986. Secchi disk science: visual optics of natural waters. Limnol. Oceanogr. 31(5):909-926.

Price, D.W. 1989. Paralytic shellfish poison analyses for August 1989. Department of Health Services, Berkley, CA, 6pp.

Price, D.W. and K.W. Kizer. 1990. California's paralytic shellfish poisoning prevention program, 1927-89. California Department of Health Services, $36 \mathrm{pp}$.

Ramp, S.R., R.W. Garwood, C.O. Davis, and R.L. Snow. 1991. Surface heating and patchiness in the coastal ocean off Central California during a wind relaxation event. J. Geophysical Res. 96(C 8):14,947-14,957.

Reidenberg, J.S. and J.T. Laitman. 1991.Laryngeal anatomy of the humpback whale (Megaptera novaeangliae). In Proceedings 9th Biennial Conference on the Biology of Marine Mammals, Chicago, IL (Abstract) p.56.

Rice, D. W. 1963. Progress report on biological studies of the larger Cetacea in the waters off California. Norsk. Hvalfangst-Tid. 52:181-187.

Rice, D. W.1971. Whales and whale research in the eastern north Pacific. Conference on the Biology of Whales, U.S. Intern. Biol. Program. Luray, Virgina. June, 35pp.

Rice, D.W. 1977. Synopsis of biological data on the sei whale and Bryde's whale in the eastern North Pacific. Rep. Int. Whal. Comm. (special issue 1): 92-97.

Rice, D. W. 1978. The humpback whale in the North Pacific: Distribution, exploitation, and numbers. In Report on a workshop on problems related to humpback whales (Megaptera novaeangliae) in Hawaii. Edited by K.S. Norris and R. Reeves. Report to the U.S. Marine Mammal Commission, Washington, D.C., p.29-44.

Ridgway, S.H. 1986. Diving by cetaceans. In Diving in Animals and Man. Edited by A.O. Brubakk, J.W. Kanwisher, and G. Sundness. The Royal Norwegian Society of Science and Letters, Trondheim, Norway, p.33-62.

Ridgway, S.H., B.L. Scronce, and J. Kanwisher. 1969. Respiration and deep diving in the bottlenose porpoise. Science 166:1651-1654. 
Schevill, W.E. 1964. Underwater sounds of cetaceans. In Marine Bio-acoustics. Edited by W.N. Tavolga, Pergamon Press, Oxford, p.307-366.

Schoenherr, J. R. 1991. Blue whales feeding on high concentrations of euphausiids around Monterey Submarine Canyon. Can. J. Zool. 69:583594.

Schwing, F.B., D.M. Husby, N. Garfield, and D.E. Tracy. 1991. Mesoscale response of coastal waters off central California to wind events during Spring 1989: Analysis of CTD surveys and AVHRR imagery. Report to California Cooperative Oceanic Fisheries Investigations, CA, 42pp.

Silber, G.K. 1986. The relationship of social vocalizations to surface behavior and aggression in the Hawaiian humpback whale (Megaptera novaeangliae). Can J. Zool. 64:2075-2080.

Simard, Y., G. Lacroix and L. Legendre. 1986. Diel vertical migrations and nocturnal feeding of a dense coastal krill scattering layer (Thysanoessa rashi and Meganyctiphanes norvegica) in stratified surface waters. Mar. Biol. 91:93-105.

Smith, R.C., P. Dustin, D. Au, K.S. Baker, and E.A. Dunlap. 1986. Distribution of cetaceans and sea-surface chlorophyll concentrations in the California current. Mar. Biol. 91:385-402.

Smith, S. E. and P. B. Adams 1988. Daytime surface swarms of Thysanoessa spinifera (Euphausacea) in the Gulf of the Farallones, California. Bull. Mar. Sci. 42(1):76-84.

Steiger, G.H., Calambokidis, J., J.C. Cubbage, J. C. Balcomb, and P. Bloedel. 1989. Size and age class of blue and humpback whales in a central California feeding area. In Proceedings 8th Biennial Conference on the Biology of Marine Mammals, Pacific Groove, CA. Abstract, p.64.

Strand, S.W. and W.M. Hamner. 1990. Schooling behavior of Antarctic krill (Euphausia superba) in laboratory aquaria: reactions to chemical and visual stimuli. Mar. Biol. 106:355-359.

Strub, T.P., P.M. Kosro, and A. Huyer. 1991. The nature of the cold filaments in the California Current system. J. Geophysical Res. 96(C 8):14,743-14,768.

Sverdrup, H.V., M.W. Johnson, and R.H. Fleming. 1942. The oceans: their physics, chemistry, and general biology. Prentice-Hall, New York.

Thompson, T.J., H.E. Winn and P.J. Perkins. 1979. Mystecete sounds. In Behavior of Marine Mammals, vol. 3. Edited by H.E. Winn and B.L. Olla. Plenum Press, New York, p.403-431. 
Washburn, L.D.C. Kadko, B.H. Jones, T. Hayward, P.M. Kosro, T.P. Stanton, S. Ramp, and T. Cowles. 1991. Water mass subduction and the transport of phytoplankton in a coastal upwelling system. J. Geophysical Res. 96(C 8):14,927-14,945.

Watkins, W. A. 1986. Whales reaction to human activities in Cape Cod waters. Mar. Mammal Sci. 2(4):251-262.

Watkins, W. A. and W.E. Schevill 1979. Aerial observation of feeding behavior in four baleen whales: Eubalaena glacialis, Balaenoptera borealis, Megaptera novaeangliae, and Balaenoptera physalus. J. Mamm. 60(1):155-163.

Webber, M.A. and S.M. Cooper. 1983. Autumn sightings of marine mammals and birds near Cordell Bank, California 1981-82. Cordell Bank Expeditions. 44pp.

White, A. W., O. Fukuhara, and M. Anraku. 1989. Mortality of fish larvae from eating toxic dinoflagellates toxins. In Red Tides:Biology, Environmental Science, and Toxicology. Edited by T. Okaichi, D.M. Anderson, T. Nemoto. Elsevier Publishing Corp., p.395-398.

Whitehead, H. 1983. Structure and stability of humpback whale groups off Newfoundland. Can. J. Zool. 61:1391-1397.

Whitehead, H. and C. Carlson 1988. Social behavior of feeding finback whales off Newfoundland: comparisons with the sympatric humpback whale. Can. J. Zool. 66:217-221.

Wiebe, P.H., S.H. Boyd, B.M. Davis, and J.L. Cox. 1982. Avoidance of towed nets by euphausiid Nematoscelis megalops. Fish. Bull. 80:75-91.

Wing, B. L. and K. Krieger. 1983. Humpback whale prey studies in southeast Alaska, summer 1982. Report to he Northwest and Alaska Fisheries Center, Auke Bay Laboratory, Auke Bay, AK, 60pp.

Winn, H.E. and L.K. Winn. 1978. The song of the humpback whale Megaptera novaeangliae in the West Indies. Mar. Biol. 47:97-114.

Würsig, B. 1988. The behavior of baleen whales. Sci. Am. 256(4):102-107.

Würsig, B., E.M. Dorsey; M.A. Fraker; R.S. Payne; W.J. Richardson; and R.S. Wells. 1984. Behavior of bowhead whales, Balaena mysticetus, summering in the Beaufort Sea: surfacing, respiration, and dive characteristics. Can. J. Zool. 62:1910-1921. 
Würsig, B., R.S. Wells; D.S. Croll. 1986. Behavior of gray whales summering near St. Lawrence Island, Bering Sea. Can. J. Zool. 64:611-621.

Youngbluth, M.J. 1976. Vertical distribution and diel migration of euphausiids in the central region of the California current. Fish Bull. 74(4):925-936.

Zar, J.H. 1984. Biostatistical Analysis (2nd edition).Prentice-Hall, Inc., Englewood Cliffs, NJ. 718pp. 


\section{APPENDIX A}

\section{DEFINED BEHAVIOR CATEGORIES:}

Behavioral states were categorized as:

1. Rest: indicated when a focal whale lies motionless near the surface for 5 min or more.

2. Slow Travel: consists of continuous, sustained swimming less than or equal to $6 \mathrm{~km} / \mathrm{h}$ ( $3 \mathrm{knots}$ ), close to the surface with little change in direction.

3. Fast Travel: consists of continuous, sustained swimming greater than $6 \mathrm{~km} / \mathrm{h}$, close to the surface with little change in direction.

4. Mill/Search: erratic, non-oriented (zig-zagging) diving with changes in speed and direction as if searching for prey. No visible prey layer detected on the depth sounder.

5. Surface Feed: circling and diving over a localized area, often lunging with mouth open at the surface. Distinct prey layer visible within the upper $10 \mathrm{~m}$.

6. Shallow Feed: circling and diving continually in the same area over a distinct prey layer detected between 10 and $60 \mathrm{~m}$ in the water column.

7. Deep Feed: circling and diving continually in the same area over a distinct prey layer detected below $60 \mathrm{~m}$ in the water column. 


\section{BEHAVIORAL ETHOGRAM:}

RESPIRATION:

\begin{tabular}{|ll|}
\hline FS & $=$ First Surlace (with no blow) \\
F & $=$ First Surface Blow \\
B & $=$ Blow \\
M & $=$ Missed Blow(s)? \\
N & $=$ No Blow Rise \\
A & $=$ Arch Back \\
$\mathbf{D}$ & $=$ Fluke-DOWN Dive \\
$\mathbf{U}$ & $=$ Fluke-UP Dive \\
H & $=$ High Fluke-UP Dive \\
NF & $=$ Not First Surtacing \\
\hline
\end{tabular}

BUBBLE \& BLOW BEHAVIOR:

\begin{tabular}{|ll|}
\hline BH & $=$ Bubbles at Blow Hole \\
BT & $=$ Bubble Trail \\
BC & $=$ Bubble Cloud \\
FB & $=$ Fountain Blow \\
WB & $=$ Wheeze Blow \\
TB & $=$ Trumpet Blow
\end{tabular}

FEEDING BEHAVIOR:

\begin{tabular}{|ll}
\hline BN & $=$ Bubble Netting \\
LL & Lateral Lunge \\
DL $=$ Diagonal Lunge \\
VL $=$ Vertical Lunge \\
UL $=$ Unidentified Lunge?
\end{tabular}

TAIL BEHAVIOR:

\begin{tabular}{|ll|}
\hline LT & $=$ Lateral Tail Display \\
TS & $=$ Tail Slap (belly-down) \\
LS & $=$ Lateral Tail Slap \\
$\Pi$ & $=$ Inverted Tail Slap (belly-up) \\
TC & $=$ Tail Clap (horizontal) \\
SW & $=$ Tail Swish (side-to-side) \\
FL & $=$ FLex (roll peduncle)
\end{tabular}

PECTORAL FIN BEHAVIOR:

\begin{tabular}{|ll|}
\hline PE & $=$ Lateral Pec Extension \\
PS & $=$ Lateral Pec Slap \\
VP & $=$ Ventral Pec Slap (belly-up) \\
RP & $=$ Roll back \& forth Pec Slap \\
PD & $=$ Pec Display
\end{tabular}

BODY BEHAVIOR:

\begin{tabular}{|ll|}
\hline HG & $=$ HanGing (horizontal at surface) \\
UN & UNdulation (bob up \& down) \\
SS & $=$ S-Shaped posture \\
ST & $=$ Sharp Turn (erratic dir. change)
\end{tabular}

HEAD AND LEAPING BEHAVIOR:

\begin{tabular}{|ll|}
\hline BR & $=$ BReach \\
$\mathrm{SH}$ & $=$ Spy Hop \\
$\mathrm{HL}$ & $=$ Head Lunge (not assoc. $w /$ feeding) \\
$\mathrm{HS}$ & $=$ Head Slap \\
WC & $=$ Whale Contact \\
$\mathrm{HO}$ & $=$ Hits Object (other than whale) \\
$\mathrm{AD}$ & $=$ Agonistic Display \\
$\mathrm{BE}$ & $=$ BEached \\
$\mathrm{SP}$ & $=$ Unidentified SPlash?
\end{tabular}

VOCALIZATIONS:

VV = Vocalization cue for recordings.

MISC. CODES:

\begin{tabular}{|ll}
$Q$ & $=$ QUESTION? (describe in comment) \\
$M D$ & $=$ Missed Data? \\
$X$ & $=$ Delete previous entry. \\
$\chi \alpha$ & $=$ Delete last sequence of entries.
\end{tabular}

* Note: Common humpback whale behaviors observed in Cordell Bank/Gulf of the Farallones region are in bold print. 


\section{APPENDIX C}

\section{DEFINED RESPIRATION VARIABLES:}

Surface-dive cycles were used as primary means of quantifying differences in behavioral states. The following five variables of respiration were measured:

1. Blow Interval (BI): time interval of 90 sec or less between exhalations at (or near) the surface.

2. Number of Blows per Surface Duration (NBS) : number of exhalations during a surface period.

3. Duration at Surface(DS) : period of time spent at (or near) the surface between successive dives. Surface duration was terminated by arching the peduncle or raising of the flukes above the water to initiate a dive, or by a submergence with blow interval exceeding 90 seconds.

4. Duration of Dive $(D D)$ : period of time during a dive to first surfacing. First exhalation exceeding $90 \mathrm{sec}$ in length usually marked the beginning of a surface duration.

5. Blow Rate (BR) : total number of exhalations divided by surface duration and dive duration from each complete surface-dive cycles.

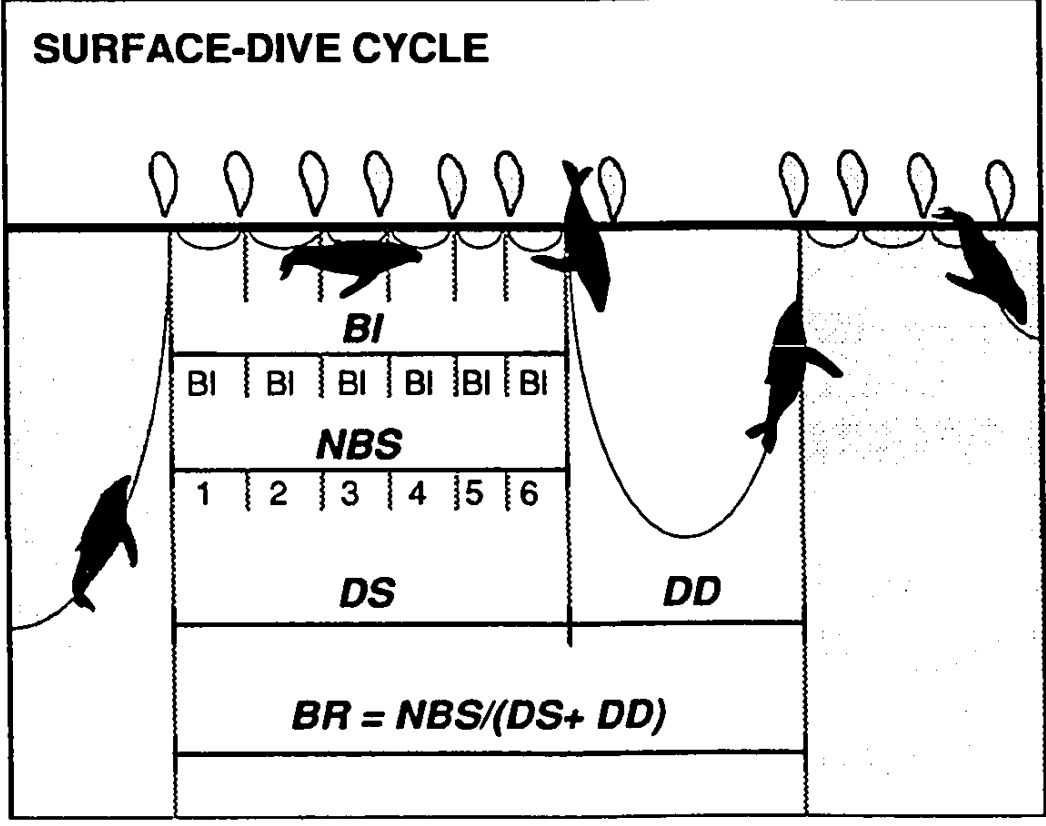




\section{APPENDIX D}

\section{RESPIRATION VARIABLES/STANDARD APPROACH:}

\begin{tabular}{|c|c|c|c|c|c|}
\hline 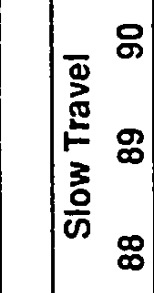 & 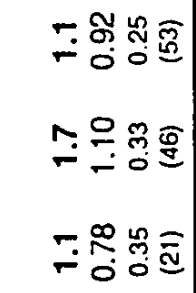 & 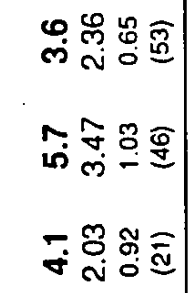 & 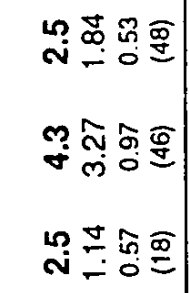 & 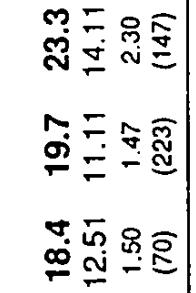 & 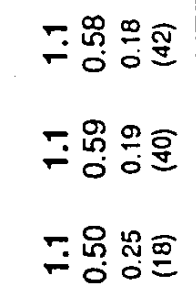 \\
\hline 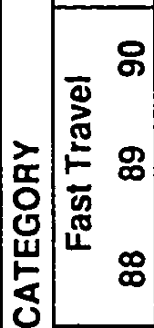 & 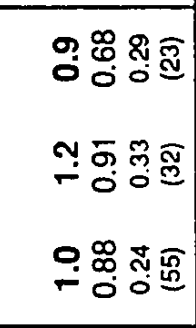 & 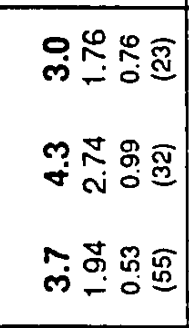 & 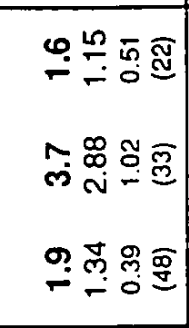 & 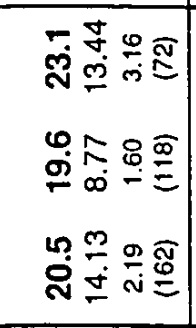 & 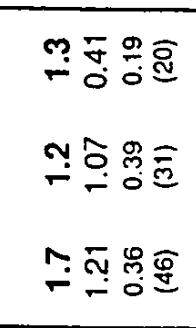 \\
\hline 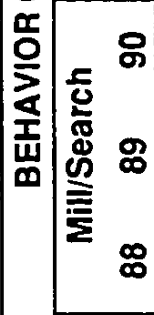 & 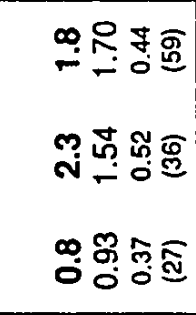 & 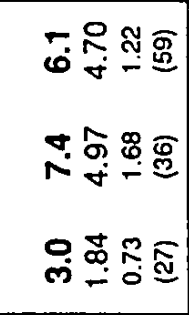 & 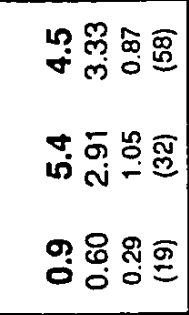 & 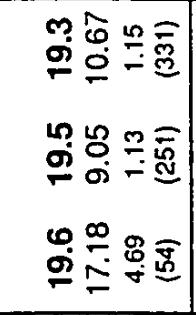 & 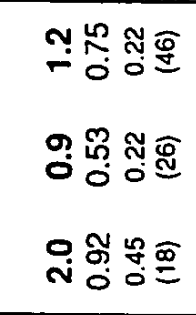 \\
\hline 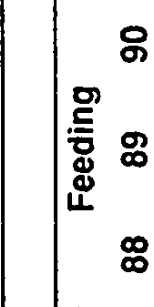 & 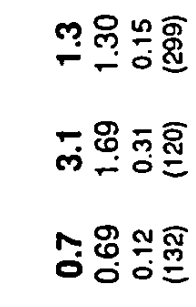 & 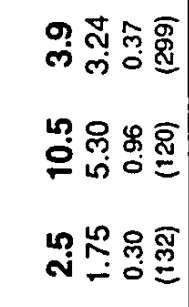 & 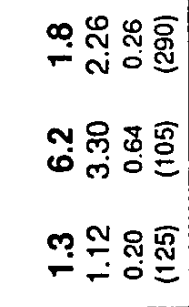 & 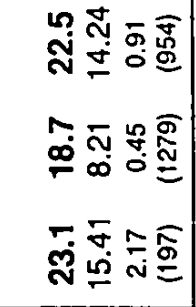 & 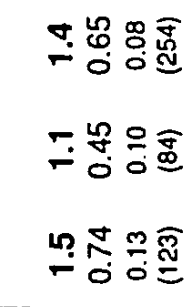 \\
\hline 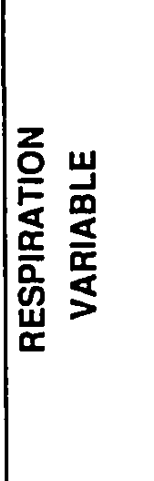 & 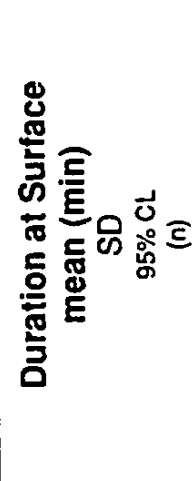 & 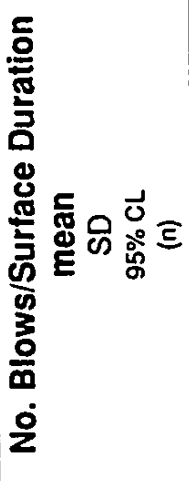 & 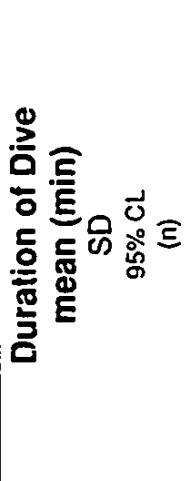 & 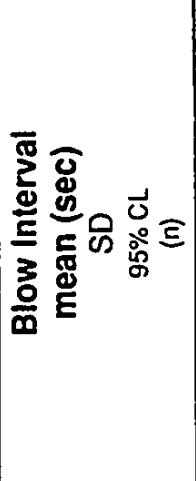 & 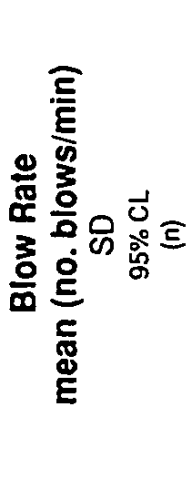 \\
\hline
\end{tabular}




\section{APPENDIX E}

STANDARD BODY LENGTH \& MANDIBLE MEASUREMENTS:

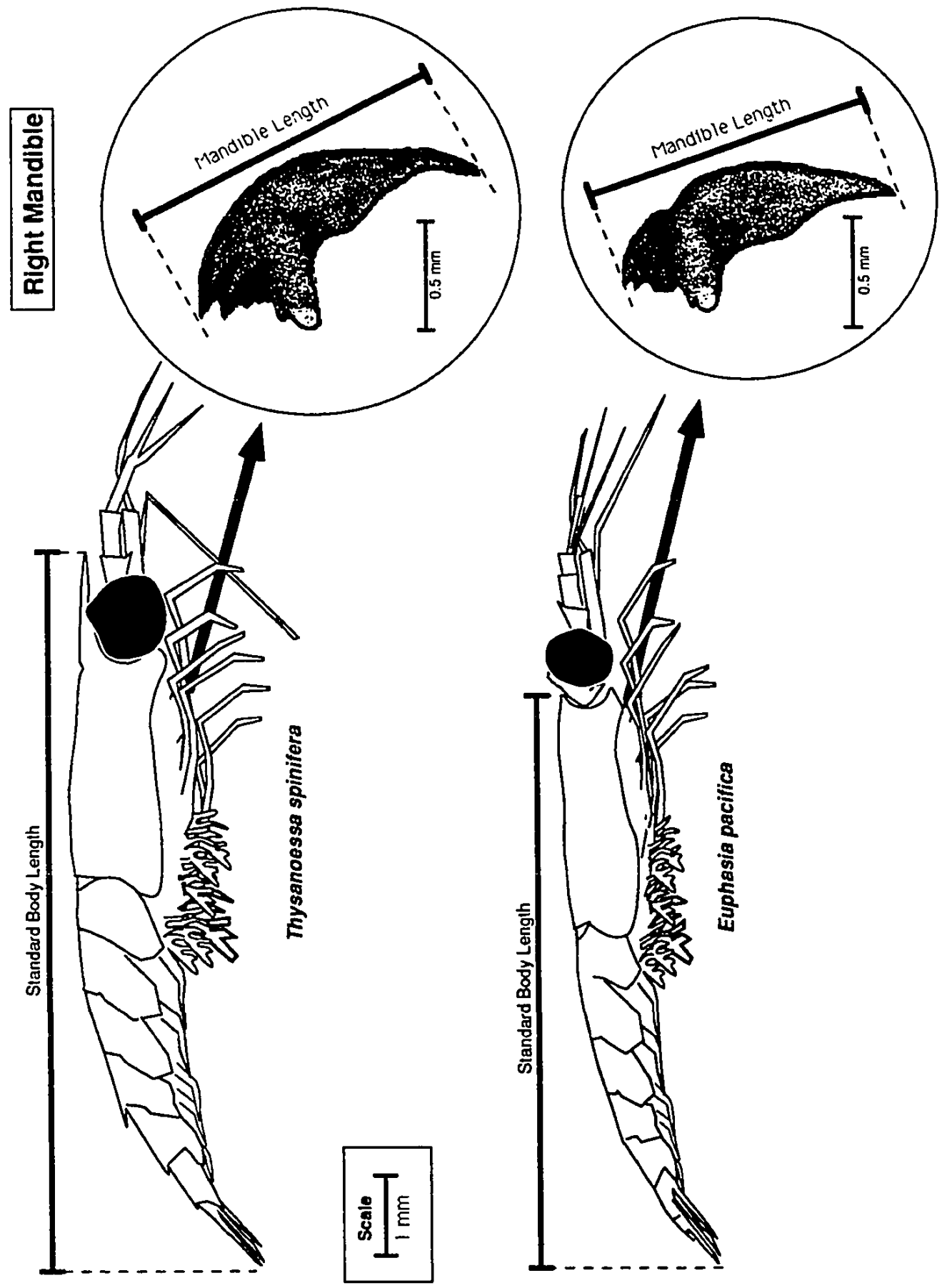




\section{APPENDIX F}

EUPHAUSIID RIGHT MANDIBLE IDENTIFICATION:

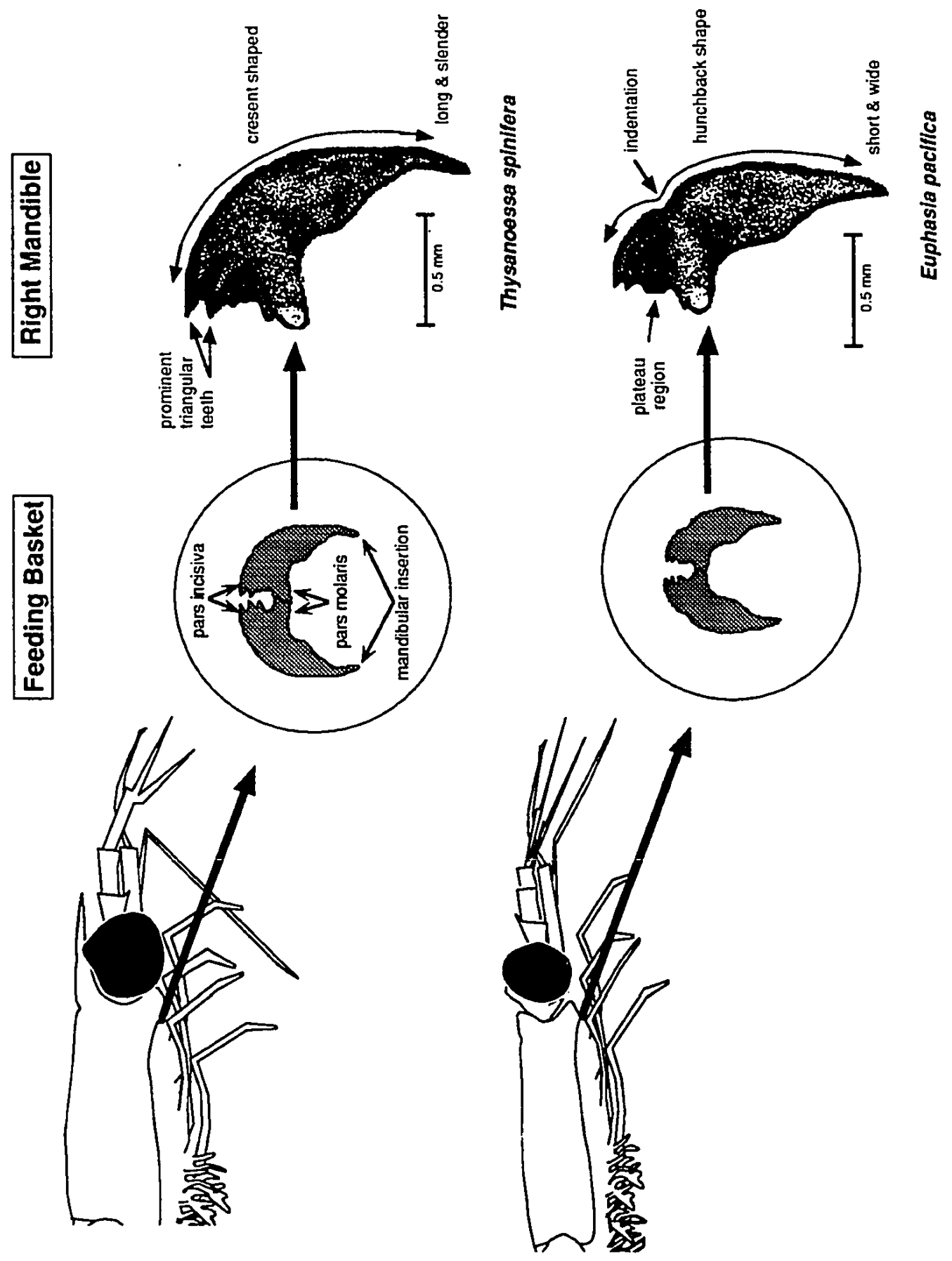




\section{APPENDIX G}

SKY CONDITION:

\begin{tabular}{|c|l|}
\hline CODE NO. & \multicolumn{1}{|c|}{ DESCRIPTION } \\
\hline 1 & Clear \\
\hline 2 & Partly cloudy \\
\hline 3 & Cloudy \\
\hline 4 & Overcast \\
\hline 5 & Light rain or rain within $6 \mathrm{~km}$ \\
\hline 6 & Heavy rain \\
\hline 7 & Patchy fog or fog within $6 \mathrm{~km}$ \\
\hline 8 & Serious fog \\
\hline 9 & Rain and fog \\
\hline
\end{tabular}

\section{SEA CONDITION (BEAUFORT):}

\begin{tabular}{|c|l|lr|c|}
\hline $\begin{array}{c}\text { BEAUF } \\
\text { NO. }\end{array}$ & \multicolumn{1}{|c|}{ DESCRIPTION } & \multicolumn{2}{|c|}{$\begin{array}{c}\text { WIND SPEED } \\
(\mathbf{k m} / \mathbf{h})\end{array}$} & $\begin{array}{c}\text { WAVE } \\
(\mathbf{m})\end{array}$ \\
\hline 0 & Smooth and mirror-like & Calm & $(0-2)$ & -- \\
\hline 1 & Light ripple & Light air & $(2-6)$ & 0.3 \\
\hline 2 & Small wavelets, not breaking & Light Breeze & $(7-11)$ & 0.6 \\
\hline 3 & Scattered whitecaps & Gentle Breeze & $(12-19)$ & 1.2 \\
\hline 4 & Small waves, frequent whitecaps & Mod. breeze & $(20-30)$ & 1.8 \\
\hline 5 & Moderate waves, many whitecaps & Fresh breeze & $(31-39)$ & 2.0 \\
\hline 6 & All whitecaps, some spray & Strong breeze & $(40-50)$ & 3.0 \\
\hline 7 & Breaking waves, spindrift begins & Near gale & $(51-61)$ & 4.3 \\
\hline 8 & Medium high waves, foamy & Gale & $(62-74)$ & 5.5 \\
\hline
\end{tabular}

*Note: Beaufort 6-8 not meaningful (time to go home!). 